\title{
Plazmonikus aranyfelületek és nanoszerkezetek felületerősített Raman-szóráshoz
}

Ph.D. értekezés

\section{Rigó István}

Témavezetö:

Veres Miklós

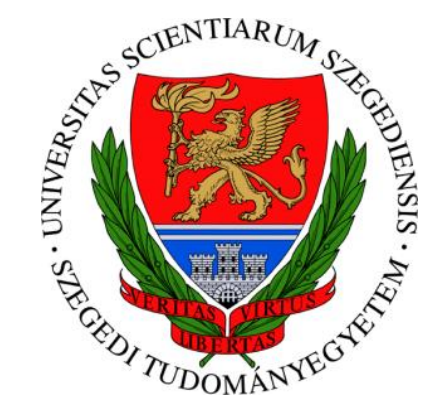

Szegedi Tudományegyetem

Természettudományi és Informatikai Kar

Fizika Doktori Iskola

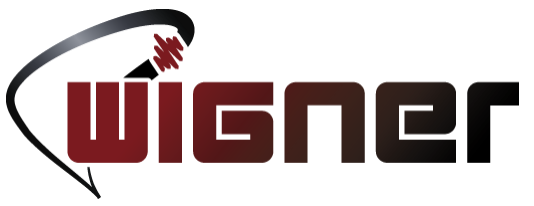

Wigner Fizikai Kutatóközpont

Szilárdtestfizikai és Optikai Intézet 


\section{Tartalom}

1. Rövidítések és jelölések jegyzéke .............................................................................................. 1

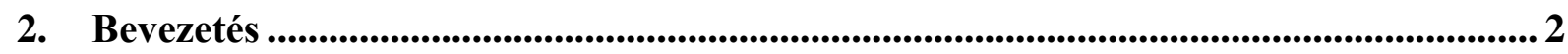

3. Irodalmi Elốzmények................................................................................................................ 4

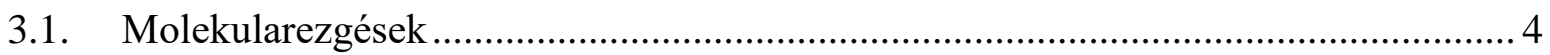

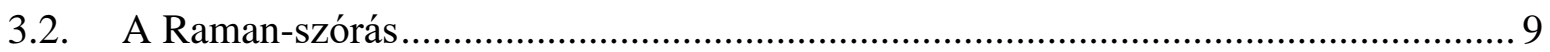

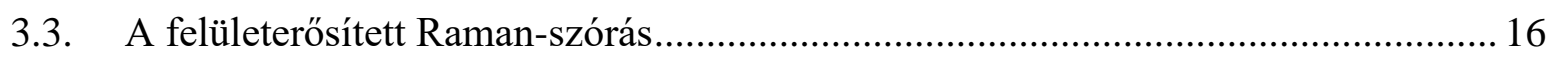

3.4. A SERS-erősítés értékének elméleti és kísérleti meghatározása ………………….... 22

3.5. Az időtartománybeli véges differenciák módszere ................................................. 24

4. Anyagok és módszerek .............................................................................................................. 28

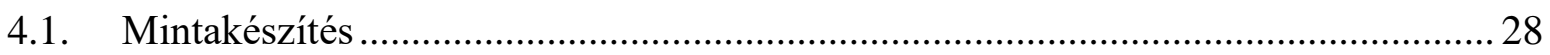

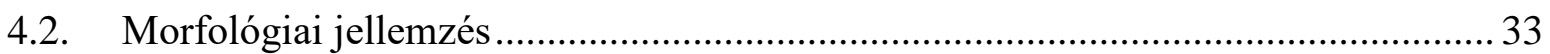

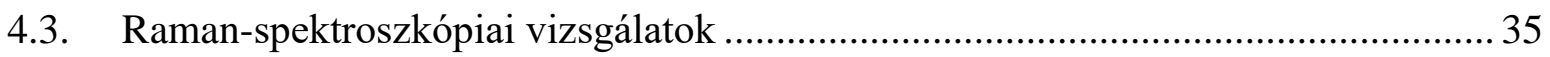

4.4. A felületerősítés meghatározása …………………….......................................... 38

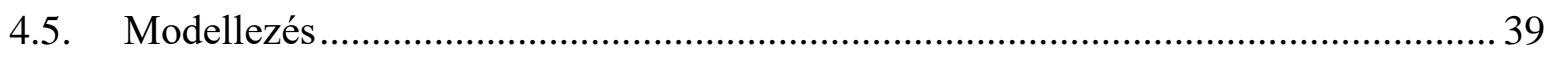

5. Eredmények ...................................................................................................................... 41

5.1. Különböző morfológiájú SERS-felületek összehasonlító vizsgálata ........................ 42

5.2. Mikroszkopikus objektumok csapdázására és SERS-vizsgálatára alkalmas perforált

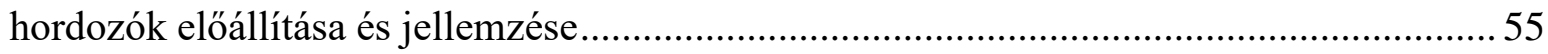

5.2.1. SERS-hordozó mikrogömbök csapdázására és jellemzésére ………………….......56

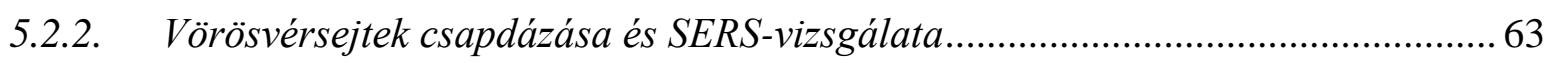

5.3. Felületerősítés arany nanogömböt tartalmazó inverz piramis SERS-hordozókon ... 70

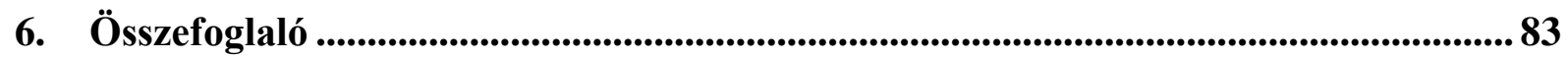

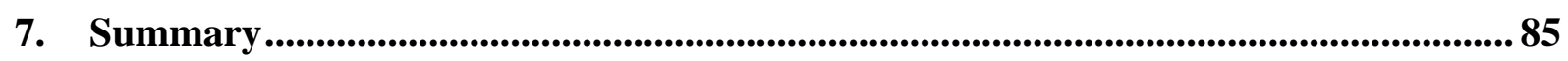

8. Tézispontokhoz kapesolódó publikációk ..............................................................................86

9. A dolgozat témaköréhez nem kapesolódó egyéb közlemények........................................ 87

10. Irodalomjegyzék.............................................................................................................................90

11. Köszönetnyilvánítás / Acknowledgement ........................................................................... 102 


\section{RÖVIDÍTÉSEK ÉS JELÖLÉSEK JEGYZÉKE}

\begin{tabular}{|c|c|c|}
\hline Rövidítés & Angol megfelelö & Magyar megfelelö \\
\hline AEF & Analytical enhancement factor & Analitikai erösítési faktor \\
\hline FDTD & Finite-difference time-domain method & $\begin{array}{c}\text { Időtartománybeli véges differenciák } \\
\text { módszere }\end{array}$ \\
\hline FIB & Focused ion beam & Fókuszált ionnyaláb \\
\hline GNP & Gold nanoparticle & Arany nanorészecske \\
\hline IR & Infrared & Infravörös \\
\hline LFIEF & Local Field Intensity Enhancement & Lokális térintenzitás-erösítési faktor \\
\hline NEF & Normal enhancement factor & Normál erösítési tényezö \\
\hline PML & Perfectly matched layer & Tökéletesen illeszkedö réteg \\
\hline RBC & Red blood cell & Vörösvérsejt \\
\hline SEM & Scanning electron microscope & Pásztázó elektronmikroszkóp \\
\hline SE & Surface enhancement & Felületerösítés \\
\hline SERS & Surface Enhanced Raman Spectroscopy & Felületerösített Raman-spektroszkópia \\
\hline SMEF & Single molecule enhancement factor & Egymolekula-erösítési tényezö (EMEF) \\
\hline SOI & Silicon on insulator & Szilícium szigetelön \\
\hline
\end{tabular}




\section{BEVEZETÉS}

A spektroszkópiai anyagvizsgálat egyik klasszikus ága a rezgési spektroszkópia; széleskörüen alkalmazott módszerei közé a Raman-spektroszkópia és az infravörös abszorpciós spektroszkópia tartozik. A Raman-szórás (más néven kombinációs fényszórás) az anyagot alkotó molekulák, kristályrács és egyéb szerkezeti egységek rezgéseivel kölcsönható fény rugalmatlan szóródása. A jelenséget 1928-ban C.V. Raman indiai tudós folyadékokban mutatta [1 - 3] ki de ugyanebben az évben tőle függetlenül Grigory Landsberg és Leonid Mandelstam kristályos anyagokon is felfedezte a Raman-szórás eredményeképp megjelenő spektrális vonalakat, és kombinációs fényszórásnak nevezte el azt. Raman valamelyest korábban publikálta tanulmányát [4], és a Nobel-dijat is ő kapta folyadékokon és gázokon végzett kutatásaiért. Az angolszász irodalomban Raman-szórásnak nevezték el a jelenséget, és napjainkra a korábban főleg a szocialista országokban használt - egyébként sokatmondó másik megnevezés szinte teljesen kikopott a használatból [5].

A Raman-spektroszkópia segítségével számos szerves és szervetlen, szilárd, folyékony és gáz halmazállapotú, rendezett és rendezetlen anyag, allotróp módosulat vizsgálható [6 - 9]. A módszer előnye, hogy nem vagy csak minimális mértékben igényel minta-elökészítést, nincs közvetlen fizikai kontaktus a mintával és - jól megválasztott mérési körülmények esetén - az nem is roncsolódik [10]. A módszer a kötésekröl ad információkat, és specifikus, a közeg fizikai tulajdonságaival kapcsolatos jellemzők kinyerésére is alkalmas, mint például egy kristály belső feszültségének vagy a minták hőmérsékletének meghatározása [11 - 13]. A modern, mikroszkóppal egybeépített Raman-spektrométerekkel nagyon kis, akár $<1 \mu \mathrm{m}$ átmérőjű térfogatból is lehet spektrumokat gyüjteni [14, 15], és nagyfelbontású két- és háromdimenziós Raman-térképek is készíthetők.

Mint minden technikának, a Raman-spektroszkópiának is megvannak a maga gyengéi: a mért spektrumokban fluoreszcenciasávok is megjelenhetnek, melyek könnyen összekeverhetök a Raman-sávokkal, illetve teljesen el is fedhetik az utóbbiakat [16, 17]. Nem minden rezgés Raman-aktív, csak azok, melyek során megváltozik a közeg polarizálhatósága [1]. Emellett a Raman-szórás hatáskeresztmetszete relatíve kicsi: az anyaggal kölcsönható minden több millió fotonból csupán néhány szenved rugalmatlan szórást [18, 19]. Emiatt a Raman-spektrum rögzítéséhez érzékeny detektorokra van szükség - ezért is volt kimagasló teljesítmény, hogy az 1920-as években előbb szabad szemmel, majd az akkori műszerekkel sikerült észlelni a Ramansávokat. 
A Raman-szórás érzékenysége ugyanakkor többféle módszerrel is javítható: ilyen a gerjesztő forrás energiájának növelése (amivel azonban megnő a fluoreszcencia gerjesztésének valószínüsége is [20]), a rezonáns Raman-szórás gerjesztése vagy a felületerösített Ramanszórás (SERS) alkalmazása [21].

A SERS egy, a Raman-szórási hatáskeresztmetszetet jelentősen, a normál Ramanszóráshoz képest akár 4-10 nagyságrenddel is megnövelni képes technika [22]. A SERS alapja a gerjesztő és/vagy a szórt fény elektromágneses terének fém nanoszerkezetek felületi plazmonjaival való kölcsönhatás általi erősítése [23], amihez a fémfelület és a minta között lezajló elektrokémiai folyamatok is hozzájárulhatnak [24]. Az erősítés mértékét számos tényező befolyásolja, legföképp a fém nanoszerkezetek (SERS-felületek vagy SERS-hordozók) anyaga, mérete és morfológiája [25]. A SERS előnye, hogy a fluoreszcens átmenettel rendelkező molekuláknál a SERS-aktív fémfelületre való adszorbeálódás után szinte teljesen megszünik a fluoreszcencia [26, 27].

A felületerősített Raman-szórás napjaink intenzíven kutatott területe [28]. A jelenség magyarázatának hosszantartó kidolgozása után a hatékony SERS-felületek előállítása, szelektívvé tétele és más módszerekkel való együttes alkalmazása állnak a kutatások fókuszában. Doktori munkám célja gyakorlati alkalmazással kecsegtető, hatékony SERShordozók kutatása: elsősorban mikroméretű objektumok, például aeroszolok, sejtek vagy baktériumok felületén található funkciós csoportok Raman-jelének vizsgálatára alkalmas felületek tervezése, előállítása, valamint kísérleti és elméleti módszerekkel való jellemzése volt. Az ilyen vizsgálatokhoz általában rögzíteni kell a vizsgálni kívánt mikroobjektumot - lehetőleg azonnal a SERS-aktív felületen.

Munkám során a következő konkrét feladatokkal foglalkoztam:

— Különböző morfológiájú és méretü üregek periodikus mátrixa alkotta SERS-hordozók összehasonlító jellemzése kísérleti és elméleti módszerekkel.

— A kapott eredmények felhasználása mikroobjektumok csapdázására alkalmas perforált, a folyadék átfolyását biztosító SERS-hordozók előállítására, és ezen hordozók jellemzése.

— Vörösvérsejtek rögzítésére és SERS-vizsgálatára alkalmas hordozók előállítása és jellemzése.

— Inverz piramisba helyezett arany nanogömbök alkotta SERS-erősítő struktúrák jellemzése. 


\section{IRODALMI ELŐZMÉNYEK}

Az alábbi fejezetben a dolgozat megértéséhez szükséges legfontosabb fogalmakat, ismereteket foglaltam össze. A fejezet első része a molekularezgések és a Raman-szórás elméleti hátterével foglalkozik - ennek a résznek a megírásához Peter Larkin, Robert W. Boyd és David L. Andrews, Andrey A. Demidov könyveire támaszkodtam [29 - 31]. Ezt követi a felületerősített Raman-szórás és a közeltér-erősítés bemutatása, mely részhez elsősorban Le Ru és Pablo G. Etchegoin, valamint Roberto Pilot és társai munkásságára támaszkodtam [32 - 34]. A fejezet utolsó része az általam alkalmazott FDTD-szimulációk elméleti hátterét ismerteti, amely leírását Yee Kane [35], valamint Zheng Zeng és társai művei alapján foglaltam össze [36].

\subsection{Molekularezgések}

A Raman-szórás során a beeső foton energiájának egy része a közeg karakterisztikus rezgéseit gerjeszti, kristályok esetében a fononokat, molekuláknál pedig a molekularezgéseket. A Raman-szórás mechanizmusának megértéséhez érdemes röviden áttekinteni a molekularezgések elméleti hátterét. Az alábbiakban a molekularezgéseket a klasszikus megközelítésben tárgyalom.

A fény-anyag kölcsönhatás egyik formája a fény abszorpciója, melynek során a közeg a foton energiájának elnyelése révén egy magasabb energiával rendelkező állapotba kerül. $\mathrm{Az}$ abszorbeált energia függvényében a folyamat a molekula elektron-, rezgési és/vagy rotációs energiájának megváltozását eredményezi [37]. Ezek nagyságrendjét az 1. ábra szemlélteti.

A molekularezgés a molekula három mozgásfajtájának egyike - a másik kettő a transzláció és a rotáció - melynek során a molekulában található atomok periodikus mozgást végeznek. Mivel a molekulákban az atomokat kémiai kötések kapcsolják össze, és a rezgés a kötések jellemzőinek változását is jelenti, a molekularezgés a kötések (kötéstávolságok és kötésszögek) periodikus változásának is tekinthető. A molekularezgések a szilárd testeknél a kristályrácsot alkotó atomok kollektív rezgéseinek, azaz a fononoknak feleltethetők meg [38]. 


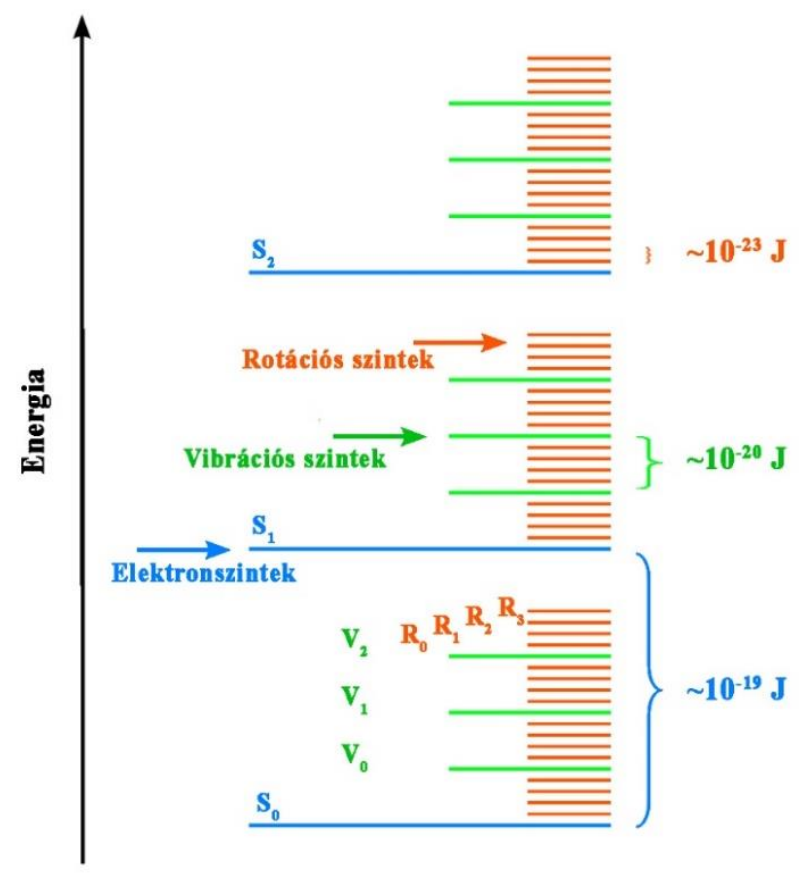

1. ábra: A molekulák elektron-, rezgési és rotációs energiáinak jellemzö értékei $\left(1 \mathrm{eV} \approx 1,6 \times 10^{-19} \mathrm{~J}\right)$. A kapcsos zárójelek a különbözö típusú gerjesztéseket és azok tipikus energiatartományát mutatják a könnyü kétatomos molekulákra.

Egy $i$ atomból álló szabad molekula szabadsági fokainak száma $3 \times i$. Ebböl három szabadsági fok a molekula transzlációját, további három pedig az ortogonális tengelyek körüli forgását írja le (lineáris molekula esetében a forgó mozgás leírásához csak két szabadsági fok szükséges). A megmaradt $3 \times i-6$ (lineáris molekula esetén $3 \times i-5$ ) szabadsági fok a molekula „belső” mozgását, azaz a rezgéseit írja le.
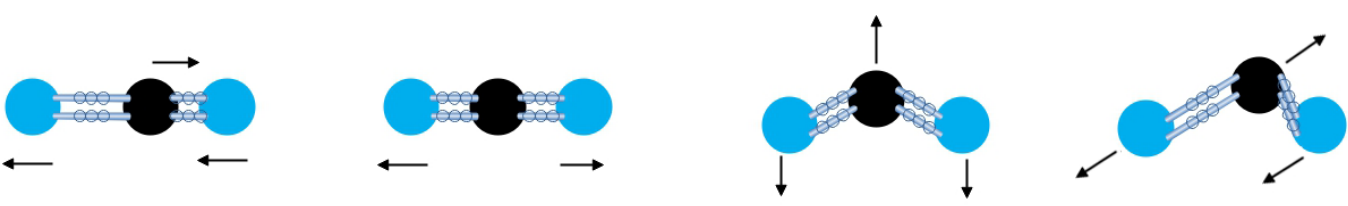

$\mathrm{CO}_{2}$
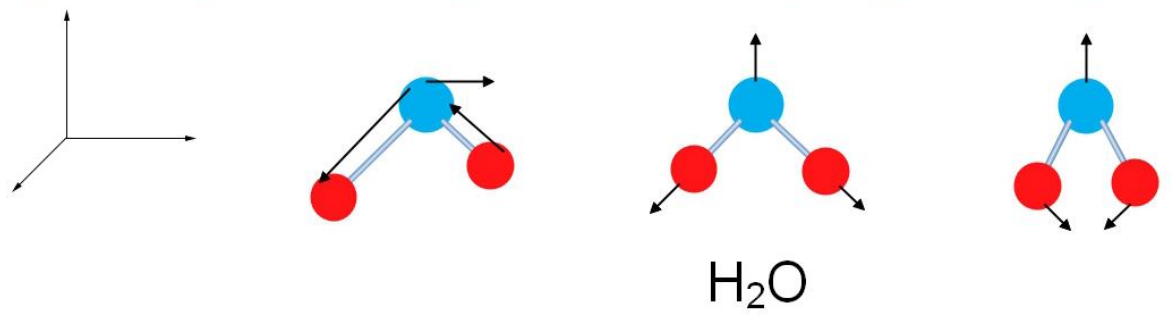

2. ábra: Háromatomos lineáris (szén-dioxid) és nemlineáris (viz) molekulák normálrezgései. 
A legegyszerübb lineáris molekulák - mint a $\mathrm{H}_{2}, \mathrm{~N}_{2}$ vagy $\mathrm{O}_{2}$ - kétatomosak, amelyek mindegyike $3 \times 2-5=1$ rezgési szabadsági fokkal rendelkezik, és egyetlen rezgése a kötés mentén végzett nyújtórezgés [29].

Lineáris (szén-dioxid) és nemlineáris (víz) háromatomos molekula normálrezgéseit mutatja a 2. ábra. A lineáris $\mathrm{CO}_{2}$-molekula $3 \times 3-5=4$ rezgési szabadsági fokkal bír. A négy rezgés a szimmetrikus és aszimmetrikus nyújtás, valamint két egymásra meröleges deformációs (hajlító-) rezgés. A szintén háromatomos, de nemlineáris vízmolekulának 3×3-6 $=3$ rezgési módusa van (2. ábra): szimmetrikus és aszimmetrikus nyújtás és egy deformációs rezgés [8].

$\mathrm{Az}$ összetett molekuláris rendszerek mozgása leírható adott rezgések lineáris kombinációjaként. Az ilyen elemi rezgéseket normálrezgéseknek vagy rezgési módusoknak nevezik, melyek mindig a teljes molekulára vonatkoznak, de vannak olyan normálrezgések, amelyek egy atomcsoport független mozgásának felelnek meg. A normálmódusok azok az alaprezgések, melyekkel az adott molekula összetett rezgései leírhatók (ugyanakkor egy normálmódus sem írható le más normálmódusokkal). Mindegyik normálmódushoz jól meghatározott rezgési frekvencia tartozik, de több normálmódusnak is lehet azonos a sajátfrekvenciája (ezek degenerált módusok) [1, 39].

A normálrezgések a mozgás fajtája és szimmetriája alapján típusokra oszthatók. A kötés hosszának periodikus változásával járó mozgásokat nyújtó- vagy vegyértékrezgéseknek, a kötésszög periodikus változását eredményező mozgásokat pedig deformációs vagy hajlitórezgéseknek nevezzük. A nyújtórezgések szögtartók, míg a deformációs rezgések hossztartók. Egy adott atomcsoportban a nyújtórezgések általában magasabb frekvenciákon oszcillálnak, mint a deformációs rezgések. Háromnál több atom deformációs rezgései között további típusokat lehet leírni, ami az elemi rezgésekre való hivatkozást könnyíti meg: létezik síkbeli deformáció - mely során az atomok mindegyike ugyanabban a síkban rezeg; síkból kilépő deformáció - ahol egy atom kitérő oszcillációt végez, a minimum további három atom által alkotott síkból [39, 40].

A Raman-spektroszkópiában az egyes normálmódusokat a következők szerint szokás jelölni:

$v$ - nyújtó (stretching) elmozdulás, a kötés hosszának megváltozása; a nyújtó módusok száma megegyezik a molekula kötéseinek számával.

$\delta$ - hajlító (bending) elmozdulás, a kötésszög változása.

$\pi$ - síkból kilépő elmozdulás. 
Az atomcsoportokra jellemző elmozdulásokat pedig a következőképp különböztetjük meg:

$\rho_{\mathrm{r}}$ - hintázó (rocking) elmozdulás, az atomcsoportok közötti szögváltozás.

$\rho_{\mathrm{w}}$ - csóváló (wagging) elmozdulás, az atomcsoport síkja közötti szögváltozás.

$\rho_{\mathrm{t}}$ - csavaró (twisting) elmozdulás, a szög változása két atomcsoport síkja között.

A szimmetriával való közvetlen korrelációban az s (szimmetrikus), as (aszimmetrikus) és d (degenerált) alindexeket használják a különféle módusok további leírásához [41]. A szilárd testekre jellemző rezgések jobb megértéséhez célszerü megvizsgálni egy váltakozó $m_{1}$ és $m_{2}$ tömegü atomok alkotta lineáris (egydimenziós) kristálymodellt (3. ábra). Ebben a pontszerüen kicsinek tekintett atomokat $\beta$ erőállandóval rendelkező rugók kapcsolják össze. Az ábra a rendszer állapotát mutatja a $t_{1}$ és $t_{2}$ időpontokban. A rendszer Brillouin-zónája $\frac{\pi}{\mathrm{X}_{0}}$ és $-\frac{\pi}{\mathrm{x}_{0}}$ között helyezkedik el [42].

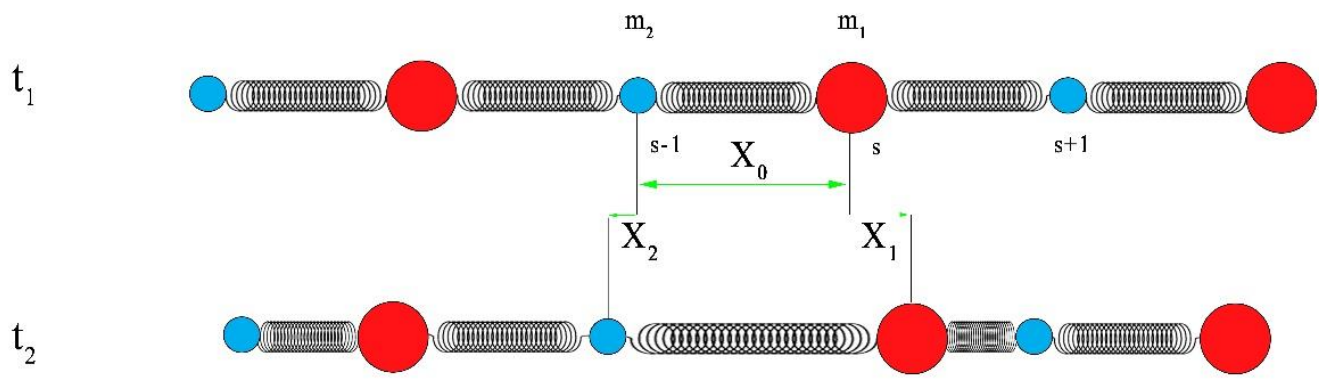

3. ábra: Kétatomos lineáris kristálymodell és elmozdulásai t és $t_{2}$ időpontokban.

Az atomokon ható eröket $F_{m 1}$ és $F_{m 2}$ az $s-1, s, s+1$ szomszédos atomok közötti relatív elmozdulások $X_{1(s)}, X_{1(s+1)}, X_{2(s)}, X_{2(s-1)}$ eredményeként írhatjuk fel [43]:

$$
F_{m 1}=m_{1} \frac{d^{2} X_{1}}{d t^{2}}=\beta\left(X_{2(s)}+X_{2(s-1)}-2 X_{1(s)}\right)
$$

és

$$
F_{m 2}=m_{2} \frac{d^{2} X_{2}}{d t^{2}}=\beta\left(X_{1(s+1)}+X_{1(s)}-2 X_{2(s)}\right)
$$

ahol $\beta$ az erőállandó vagy „rugóállandó”. A differenciálegyenlet megoldásához szükséges elmozdulásokat pedig a következő összefüggések adják meg: 


$$
\begin{gathered}
X_{1(s)}=R_{1} e^{-i s k X_{0}} e^{-i \omega t} \\
X_{2(s)}=R_{2} e^{-i s k X_{0}} e^{-i \omega t},
\end{gathered}
$$

ahol $R_{1}$ és $R_{2}$ az elmozdulások amplitúdói, $k$ a hullámvektor, $\omega$ pedig a frekvencia. Ennek megoldásaként a megfelelő matematikai eljárások és Euler-összefüggések alkalmazásával [43] a következő diszperziós egyenlet adódik:

$$
\omega(k)=\sqrt{\frac{\beta\left(m_{1}+m_{2}\right)}{m_{1} m_{2}} \pm \beta \sqrt{\frac{\left(m_{1}+m_{2}\right)^{2}}{m_{1}^{2} m_{2}^{2}}-\frac{4}{m_{1} m_{2}} \sin ^{2}\left(\frac{k X_{0}}{2}\right)}}
$$

ahol $X_{0}$ az egyensúlyi állapotok közötti távolság vagy más néven egyensúlyi kötéshossz, rácsállandó. A fenti összefüggésböl jól látható, hogy a diszperziót az atomok tömege, az erőállandó és a rácsállandó is befolyásolja. A gyök alatt a +/- jel a diszperzió két ágát jelzi.

Nézzük meg azt az esetet, amikor $m_{1}=m_{2}=m$. Ekkor a (3) egyenlet az alábbira egyszerüsödik:

$$
\omega(k)=\sqrt{\frac{\beta}{m} \pm \beta \sqrt{\frac{1}{m^{2}}-\frac{4}{m^{2}} \sin ^{2}\left(\frac{k X_{0}}{2}\right)}} .
$$

Amikor a lineáris kristályt azonos tömegü atomok alkotják, ezek csak úgy mozoghatnak, mintha egy rugalmas szálra lennének felfüzve. Az ilyen, azonos fázisban kitérő atomok alkotta hullámokat akusztikus módusoknak hívjuk (4. ábra), mert szerepet játszanak a hanghullámok szilárd anyagokban való terjedésében [44].

Amennyiben $\mathrm{m}_{1} \neq \mathrm{m}_{2}$, úgy a rendszernek másfajta rezgései is megjelenhetnek. A különböző tömegü atomok is képesek fázisban, egy hullámot alkotva rezegni, itt is megfigyelhető akusztikus módus. Olyan mozgás is lehetséges, melynek során a különböző tömegü atomok ellentétes fázisban oszcillálnak. Ezen rezgések frekvenciái magasabb frekvenciatartományba (lásd: 4. ábra), akár a spektrum infravörös tartományába is eshetnek, ezért optikai módusoknak nevezik őket [40]. A (4) képletben a $\pm \beta \sqrt{\frac{\left(m_{1}+m_{2}\right)^{2}}{m_{1}{ }^{2} m_{2}{ }^{2}}-\frac{4}{m_{1} m_{2}} \sin ^{2}\left(\frac{k X_{0}}{2}\right)}$ gyök alatti rész a két ág, az optikai ág és az akusztikus ág megjelenését eredményezi a diszperzióban. Ez a kettősség mind a hosszanti, mind a keresztirányú hullámok esetében megfigyelhető [45]. 


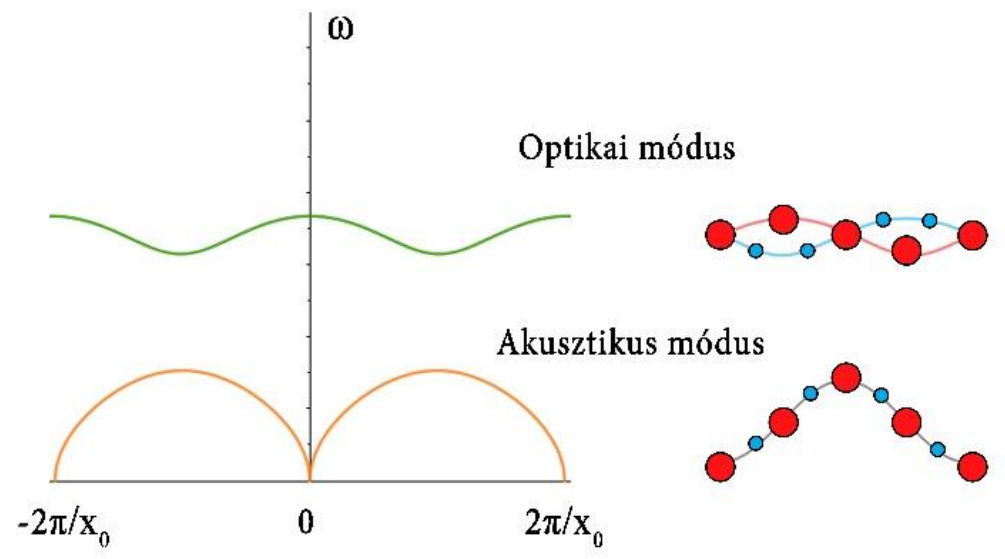

4. ábra: Kétatomos lineáris kristály lehetséges rezgési módusainak ábrázolása a k-térben.

Az akusztikus és optikai módusok diszperzióját a 4. ábra mutatja. Látható, hogy az akusztikus módus diszperziójának minimuma, míg az optikai módusnak maximuma van a Brillouin-zóna közepén és szélein [46].

\subsection{A Raman-szórás}

A fény és az anyag (molekulák, szilárdtestek) között számos kölcsönhatás léphet fel, melyek közül a legfontosabbakat az 5. ábra mutatja [47, 48]. A közeg belső szerkezetének és a kölcsönható fény energiának függvényében a fény reflektálódhat, abszorbeálódhat, rugalmasan vagy rugalmatlanul szóródhat. A sugárzási mezőt közismert módon kvantáljuk $\left(h v_{f}\right)$, mint ahogy az sem újdonság, hogy az anyagrendszer $\left\{\mathrm{W}_{\mathrm{n}}\right\}$ energiaspektrummal bír. A $\mathrm{W}_{0}$ alapállapot energiája, az összes többi $\mathrm{n}$ sajátértéknél $\mathrm{W}_{\mathrm{n}}$ gerjesztési energiával rendelkezik [49].

Az abszorpciós folyamat során az anyag egy magasabb energiaállapotba kerül, ami akár hibrid állapot is lehet (elektromos és vibrációs állapot összessége). Abban az esetben is előfordulhat abszorpció, ha a foton energiája nem elegendő egy elektronátmenet gerjesztéséhez, ilyenkor két vagy több foton együttes energiája kell, hogy megegyezzen egy átmenetével. A molekulák a gerjesztett állapotból alacsonyabb állapotba nem csak az elnyelttel azonos frekvenciájú foton kisugárzásával térhetnek vissza, hanem rendszerint más energiaállapotokba való átmenettel is, tehát eltérő - általában hosszabb - hullámhosszú foton kisugárzása (lumineszcencia) útján. A gerjesztett vibrációs szintekről történhet spontán relaxáció, amikor a rendszer energiája foton kibocsátás nélkül csökken, ezáltal annak melegedését okozva. Ahogy már fentebb szó esett róla, végbemennek szórási folyamatok is, melynek mechanizmusát az alábbiakban taglaljuk. 


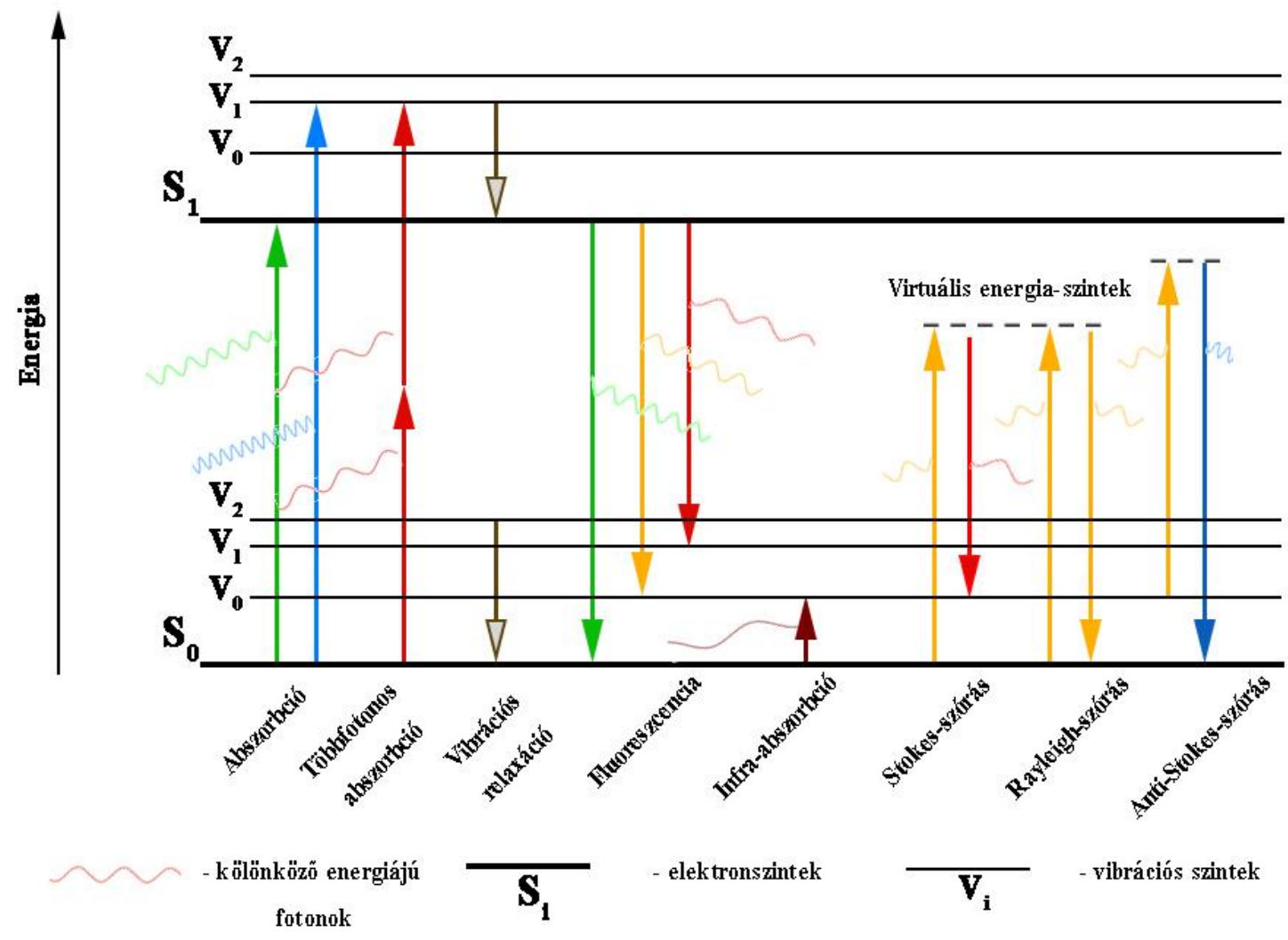

5. ábra: A fény-anyag kölcsönhatás különbözö formáinak módositott

\section{Jablonski-diagramja [47].}

A rugalmatlan szórási folyamat az anyagi rendszer állapotának megváltozását eredményezi a kiindulási és a végállapot között, mely során energiacsere megy végbe a sugárzási mezővel. Monokromatikus fény szórása során a detektált fény spektrumában sokszor a beeső fény $v_{f}$ frekvenciája mellett más $v_{s}=v_{f} \pm v_{q}$ frekvenciáknál is megfigyelhető intenzitás. A $v_{f}$ változtatásával az eltolódások $W_{q}=h v_{q}$ energiája változatlan marad, azok mértékét és a hozzájuk tartozó szórási intenzitásokat is a kölcsönható közeg határozza meg. Ez a jelenség a Raman-szórás.

A Raman-mérés során a szórt fény intenzitásának hullámhossz szerinti eloszlását detektáljuk, és azt a $\Delta \bar{v}$ relatív hullámszám szerint ábrázoljuk, melyet hagyományosan $\mathrm{cm}^{-1}$ mértékegységben adunk meg. A beeső fény hullámszámát zérusnak véve a relatív hullámszámot az alábbi összefüggés határozza meg [50, 29]:

$$
\Delta \bar{v}=\left(\frac{1}{\lambda_{f}}-\frac{1}{\lambda_{s}}\right) .
$$


A Raman-szórás során a fény rugalmatlanul szóródik a közeg elemi gerjesztésein. A rugalmatlan fényszórás olyan folyamat, melynek során a $h v_{f}$ energiájú beeső foton energiaátadással abszorbeálódik a közegben, és egy $h v_{s}$ energiájú szórt foton keletkezik. Az elemi gerjesztés molekuláknál általában valamilyen rezgési átmenetet jelent, míg kristályokban a többféle lehetséges gerjesztés közül általában a rácsrezgések (fononok) vesznek részt a Raman-szórásban [51].

A $v_{f}$ frekvenciájú monokromatikus beeső fény hatására a közeg atomjaira $E=$ $\alpha E_{0} \cos \left(2 \pi v_{f} t\right)$ időben változó elektromos tér hat, ami $P$ dipólusmomentumot indukál $[52,31]$ :

$$
P=\varepsilon_{0} \chi_{i j} E=\varepsilon_{0} \chi_{i j} E_{0} \cos \left(2 \pi v_{f} t\right)
$$

ahol $\varepsilon_{0}$ a dielektromos állandó vákuumban, $\widehat{\chi_{\imath \jmath}}$ pedig a szuszceptibilitás, ami tenzormennyiség és a közeg jellemzője. A kettő szorzata pedig nem más, mint az anyag polarizálhatósága: $\alpha_{i j}=\varepsilon_{0} \chi_{i j}$. Mint látni fogjuk, a polarizálhatóság nagyon fontos mennyiség az anyagok Ramanaktivitásának szempontjából $[53,54]$.

A polarizálhatóság felírható a molekula $q$ rezgési normálmódusához tartozó $Q_{q}$ normálkoordináták és a $Q=0$ egyensúlyi helyzetre végzett sorfejtés segítségével is:

$$
\alpha_{i j} \approx \alpha_{0}+\sum_{q}\left(\frac{\delta \alpha_{i j}}{\delta Q_{q}}\right)_{Q=0} \cdot Q_{q}+\frac{1}{2} \sum_{q}\left(\frac{\delta^{2} \alpha_{i j}}{\delta Q_{q}{ }^{2}}\right)_{Q=0} \cdot Q_{q}{ }^{2}
$$

ahol $\alpha_{0}$ az egyensúlyi helyzethez tartozó polarizálhatóság. A rezgési normálkoordináta tehát így fejezhetö ki:

$$
Q_{q}=Q_{0} \sin \left(2 \pi v_{q} t\right)
$$

ahol $v_{q}$ a rezgés frekvenciája.

A (8) beillesztésével a (7)-be, és a magasabb rendü tagok elhagyásával:

$$
\alpha_{i j}=\alpha_{0}+\sum_{q}\left(\frac{\delta \alpha_{i j}}{\delta Q_{q}}\right)_{Q=0} \cdot Q_{0} \sin \left(2 \pi v_{q} t\right)
$$


A fenti összefüggéseket felhasználva újra felírhatjuk a $P$ értékét az idő függvényében:

$$
\begin{gathered}
P=\left(\alpha_{0}+\sum_{q}\left(\frac{\delta \alpha_{i j}}{\delta Q_{q}}\right)_{Q=0} \cdot Q_{0} \sin \left(2 \pi v_{q} t\right)\right) \cdot E_{0} \sin \left(2 \pi v_{f} t\right)= \\
=\alpha_{0} E_{0} \sin \left(2 \pi v_{f} t\right)+\sum_{q}\left(\frac{\delta \alpha_{i j}}{\delta Q_{q}}\right)_{Q=0} \cdot Q_{0} E_{0} \cdot \sin \left(2 \pi v_{q} t\right) \cdot \sin \left(2 \pi v_{f} t\right)= \\
=\underbrace{\alpha_{0} E_{0} \sin \left(2 \pi v_{f} t\right)}_{\text {Rayleigh }}+ \\
+\underbrace{\left.\sum_{q}\left(\frac{\delta \alpha_{i j}}{\delta Q_{q}}\right)_{\underline{Q=0}}^{v_{f}-v_{q}}\right) t-\cos 2 \pi(\underbrace{v_{f}+v_{q}}_{\text {anti-Stokes }}) t}_{\text {Raman }}) .
\end{gathered}
$$

Egy adott frekvenciával rezgő dipólus ugyanolyan frekvenciával rendelkező elektromágneses sugárzást bocsát ki. A (10) egyenlet azt mutatja, hogy a molekula dipólusmomentuma három különböző frekvenciájú összetevőt tartalmaz. Az első komponens frekvenciája megegyezik a gerjesztő elektromos terével - az ehhez kapcsolódó folyamat a rugalmas vagy Rayleigh-szórás. A másik két tag esetében a $\left(v_{f}-v_{\boldsymbol{q}}\right)$ és a $\left(v_{f}+v_{\boldsymbol{q}}\right)$ frekvencia eltér a gerjesztő elektromos tértől, azaz rugalmatlan szórás történik - ezek rendre a Stokes és az anti-Stokes Raman-szórási folyamatoknak felelnek meg. A három komponenst a szilícium szórási spektrumában a 6 . ábra szemlélteti.

A (10) egyenletböl következik, hogy a Raman-szórás megfigyelésének feltétele az alábbi Raman-szórási tenzor 0-tól való különbözősége [31]:

$$
\widehat{R_{q}}=\left(\frac{\delta \alpha_{i j}}{\delta Q_{q}}\right)_{Q=0} \neq 0
$$

A fenti összefüggés jelenti a Raman-szórásra vonatkozó kiválasztási szabályt, azaz azt a feltételrendszert, ami az egyes kölcsönhatások létrejöttéhez szükséges. Tekintsük meg részletesebben a kiválasztási szabályt. 
Foton energia $(\mathrm{eV})$

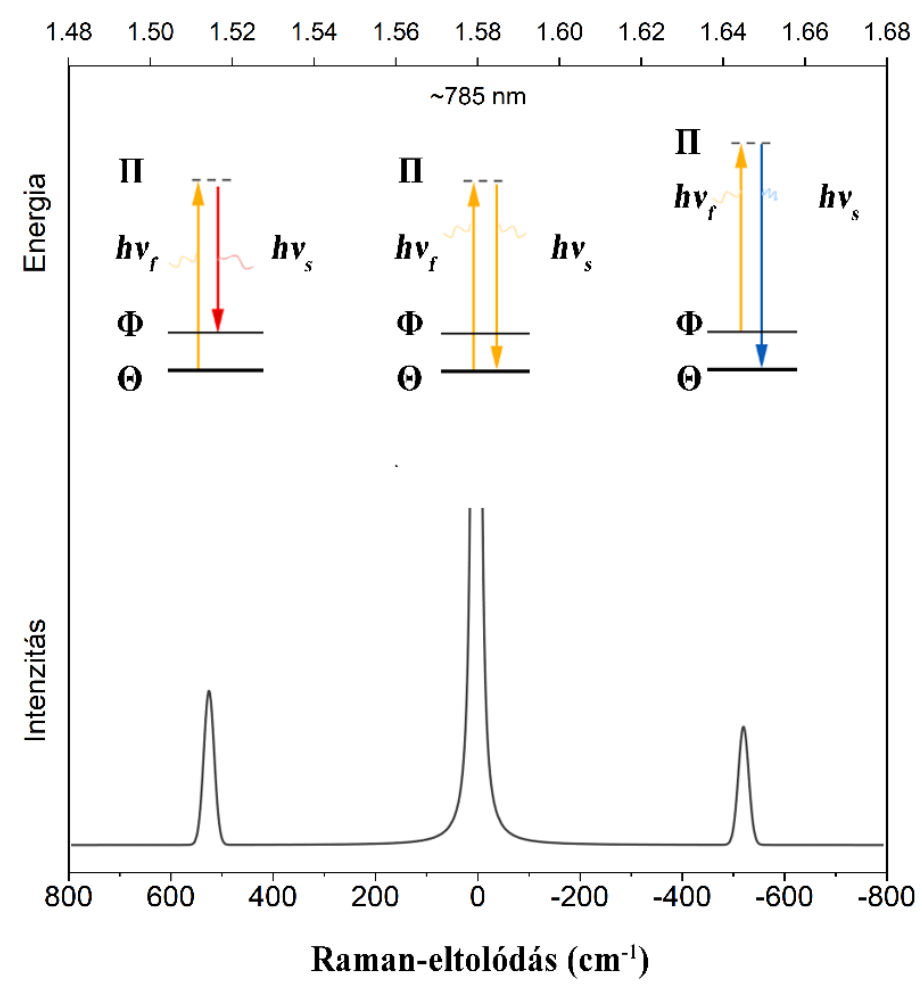

6. ábra: A kristályos szilícium Raman-spektruma 785 nm-es gerjesztési fotonenergia mellett. Középen, 0 hullámszámnál a Rayleigh-szórás, $520 \mathrm{~cm}^{-1}$-nél a Stokes, $-520 \mathrm{~cm}^{-1}$-nél pedig az anti-Stokes Raman-szórási csúcsok láthatók.

A (6) egyenletben 3 vektormennyiség látható, melyek mátrixalakban is felírhatók:

$$
\left(\begin{array}{l}
P_{x} \\
P_{y} \\
P_{z}
\end{array}\right)=\varepsilon_{0}\left(\begin{array}{lll}
\chi_{x x} & \chi_{x y} & \chi_{x z} \\
\chi_{y x} & \chi_{y y} & \chi_{y z} \\
\chi_{z x} & \chi_{z y} & \chi_{z z}
\end{array}\right)\left(\begin{array}{l}
E_{x} \\
E_{y} \\
E_{z}
\end{array}\right)
$$

A kifejezésben szereplő $3 \times 3$ másodrendű mátrix az $\alpha_{i j}$ polarizálhatósági tenzor. A hagyományos (nem rezonáns) Raman-folyamat során ez a tenzor szimmetrikus, tehát $\alpha_{i j}=\alpha_{j i}$. Amennyiben ezek az elemek a rezgés során változnak, a rezgési módus Raman-aktívvá válik, amit grafikusan így ábrázolhatunk: 


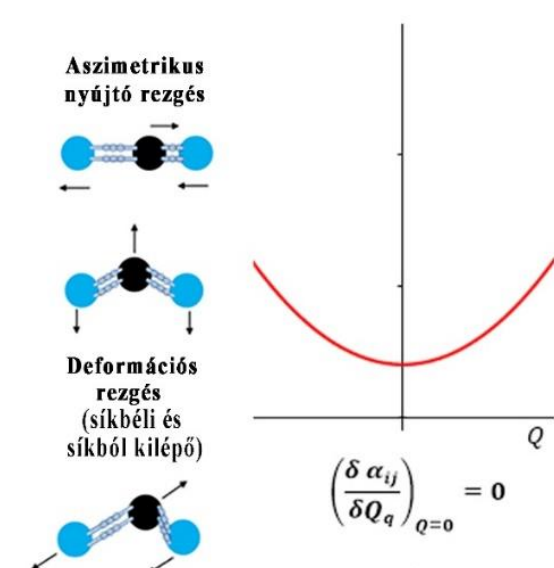

Raman-inaktív

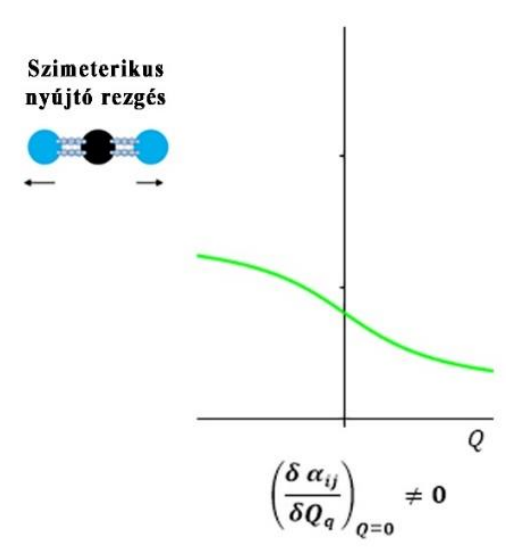

Raman-aktív

7. ábra: A Raman-szórás kiválasztási szabályának grafikus ábrázolása: a polarizálhatóság változása a $\mathrm{CO}_{2}$ Raman-inaktív és -aktív normálmódusainak példáján.

Az indukált dipólusmomentum segítségével tehát bemutattuk, hogy az átmenet Ramanaktivitásának feltétele a polarizálhatóság megváltozása.

Mechanizmusát tekintve a Raman-szórás egy háromlépcsős folyamat [55], melynek elemei kristályos anyagokra és fononokra az alábbiak szerint fogalmazhatók meg (8. ábra):

\section{STOKES -FOLYAMAT}

1. a $h v_{f}$ energiájú, $k_{f}$ hullámvektorral rendelkező beeső foton egy $e^{-}-e^{+}$elektron-lyuk párt gerjeszt: az elektron $\Theta$ alapállapotból П köztes állapotba kerül;

2. az elektron-lyuk pár egy $h v_{q}$ energiával és $q$ hullámvektorral rendelkező fonont kibocsátva, valamint $h v_{s}=h\left(v_{f}-v_{q}\right)$ energiájú, $k_{s}$ hullámvektorral rendelkező szórt fotont kisugározva rekombinálódik: az elektron П köztes állapotból $\Phi$ végállapotba kerül.

\section{ANTI-STOKES -FOLYAMAT}

1. a $h v_{f}$ energiájú, $k_{f}$ hullámvektorral rendelkező beeső foton egy $e^{-}-e^{+}$elektron-lyuk párt gerjeszt miközben egy $h v_{q}$ energiával és $q$ hullámvektorral rendelkező fonon elnyelődik: az elektron $\Theta$ alapállapotból П köztes állapotba kerül;

2. az elektron-lyuk pár egy $h v_{s}=h\left(v_{f}+v_{q}\right)$ energiájú, $k_{s}$ hullámvektorral rendelkező szórt fotont kisugározva rekombinálódik: az elektron $\Pi$ köztes állapotból $\Phi$ végállapotba kerül. 


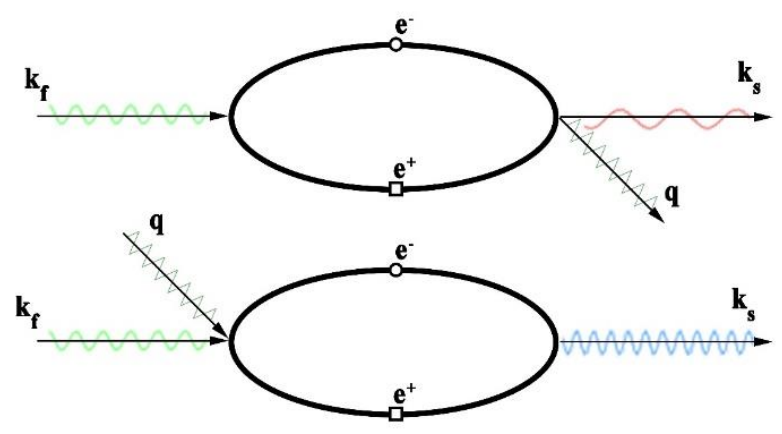

8. ábra: Raman-szórás mechanizmusa a Stokes-(felsö) és anti-Stokes-folyamat (alsó) esetében.

A Raman-szórásra is érvényesek a megmaradási törvények $[48,56]$ :

$$
h v_{s}=h v_{f} \pm h v_{q}, k_{f}=k_{s} \pm q
$$

Itt $h v_{f}$ a beeső, $h v_{s}$ a szórt foton energiája. A (13) alapján $q$-nak a fotonok $k_{s}$ és $k_{f}$ hullámvektora közötti különbséget kell kompenzálnia [57].

Kvantummechanikai olvasatban a fény-anyag kölcsönhatás során a sugárzási mezőt a $\mathcal{H}_{R}$ Hamilton-operátorral határozhatjuk meg legpontosabban. A vizsgálni kívánt anyagrendszert pedig (szilárdtest, molekula, atom, oldat stb.) a $\mathcal{H}_{A}$ Hamilton-operátor. A fényagyag kölcsönhatást pedig a $\mathcal{H}_{A R}$ operátorral írhatjuk le [49].

Nem minden foton szenved rugalmatlan szórást, több millióból csupán néhány. Az összefüggést, amely meghatározza a folyamat valószínűségét, differenciális hatáskeresztmetszetnek hívjuk, melyet az időfüggő perturbációs elmélet segítségével mutatunk be, terjedelemi miatt csak a Stokes-folyamat esetére [58]:

$$
d \sigma\left(k_{f}, \sigma ; \omega_{s}, \widehat{\theta}, \rho\right)=\left(\frac{d \Omega}{4 \pi^{2} \hbar^{4} c^{4}}\right) \sum_{\Phi}\left|K_{2 f, 10}\right|^{2} \delta\left(\hbar \omega_{s}+W_{\Phi}-\hbar \omega_{f}\right)
$$

ahol $\sigma, \rho$ rendre a beeső és a szórt foton polarizációja; $d \Omega$ térszög $\hat{\theta}$ irányban; $W_{\Phi}$ anyagrendszer végállapotának energiája; $K_{2 f, 10}$ a kezdő és a végállapotokat összekapcsoló $\boldsymbol{H}_{\boldsymbol{A R}}$ operátor magasabb rendủ átmeneti mátrixeleme, melynek négyzete arányos az $I_{R S}$ Raman-szórási intenzitással:

$$
I_{R S} \sim\left|K_{2 f, 10}\right|^{2}
$$


A (14) és (15) alapján elmondható, hogy a differenciális Raman-szórási hatáskeresztmetszetet és az intenzitást is a $K_{2 f, 10}$ átmeneti mátrixelem tulajdonságai határozzák meg. Ennek alakja:

$$
\begin{aligned}
K_{2 f, 10}=\sum_{i}\{ & \frac{\left\langle\omega_{s} \Phi\left|\mathcal{H}_{A R}\right| \Theta \Pi\right\rangle\left\langle\Theta \Pi\left|\mathcal{H}_{A R}\right| \omega_{f} \Theta\right\rangle}{h \omega_{f}-W_{\Pi}} \\
& \left.+\frac{\left\langle\omega_{s} \Phi\left|\mathcal{H}_{A R}\right| \omega_{s} \omega_{f} \Pi\right\rangle\left\langle\omega_{s} \omega_{f} \Pi\left|\mathcal{H}_{A R}\right| \omega_{f} \Theta\right\rangle}{-h \omega_{s}-W_{\Pi}}\right\},
\end{aligned}
$$

ahol $\Theta, \Pi, \Phi$ az anyagrendszer alap-, köztes-, illetve végállapota.

Az anyagrendszer $\left\{W_{\Pi}\right\}$ spektruma általában nem ismert. Abban az esetben, ha a gerjesztő foton energiája megközelítőleg megegyezik, egy az anyagra jellemző $W_{\Pi}$ energiaszinttel a (16) egyenlet nevezője közelít a nullához, rezonáns gerjesztés jöhet létre, melynek eredményeképp több nagyságrenddel megnövekedhet a Raman-szórási hatáskeresztmetszet.

\subsection{A felületerősített Raman-szórás}

A felületerősített Raman-szórást először 1974-ben Fleischmann és társai fedezték fel [59], akik váratlanul nagy Raman-jelről számoltak be az érdesített ezüstelektródán adszorbeált piridin mérésekor. Jeanmaire és van Duyne [60], valamint Albrecht és Creighton [61] megerősítették Fleischmannék megfigyeléseit, és saját kísérleteik alapján azt feltételezték, hogy a jelenséget a fémfelületen megjelenő erős elektrokémiai eredetű elektromágneses mezők vagy molekula-fém komplexek kialakulása okozza. Moskovits [62, 63] elgondolása szerint a Ramanjel megnövekedése a nanoszerkezetü fémfelülethez köthető, és az elektronok kollektív oszcillációjának optikai gerjesztése áll mögötte. Az ezt követő kutatások azt mutatták, hogy a SERS-nek két oka lehet, melyek elektromágneses [32, 64] és kémiai eredetre vezethetők vissza [65]. A SERS rendelkezik a hagyományos Raman-szórás előnyös tulajdonságaival, mint a molekulák azonosításának lehetősége a rezgési Raman-spektrum jelentette ujjlenyomat alapján, a roncsolásmentesség, a minimális mintaelőkészítés, a különböző alkotórészek egyidejü detektálása (multiplexálás). További előnyként említhető a biológiai anyagok szelektív vizsgálatának lehetősége, mivel a víz SERS-spektruma meglehetősen gyenge [66], valamint a nagy érzékenység, ami bizonyos esetekben akár egy molekula detektálását is lehetővé teszi [67].

A szakirodalom kétféle erősítési mechanizmussal magyarázza a felületerősített Ramanszórás kialakulását [33]. A kémiai erősítés során a molekula és a fémfelület között kémiai kötés jön létre. Ennek következtében töltésátadás történik a molekula és a fémfelület között, és új 
elektronállapotok keletkeznek [8]. Mindez egyrészt megnöveli a polarizálhatóságot, másrészt az új elektronállapotok közremüködésével rezonáns Raman-szórás is kialakulhat [58, 68]. Mindez együttesen 2-4 nagyságrendnyi SERS-erősítést eredményez. A doktori munkám keretében vizsgált SERS-felületekre ez az erősítési mechanizmus nem volt jellemző, ezért ezt részletesebben nem tárgyalom. Az alábbi források viszont alapos betekintést nyújtanak a kémiai erősítés mechanizmusába [69 - 72].

A másik, akár 4-8 nagyságrend erősítést is eredményező SERS-erősítési mechanizmus az elektromágneses erősítés [73]. Ennek lényege, hogy a külső elektromágneses tér a fémek felületén található szabad elektronok kollektív oszcillációját okozza. Ezeket az oszcillációkat felületi plazmonoknak nevezik [74]. A felületi plazmonok rezonanciafrekvenciával rendelkeznek, és amennyiben a külső tér frekvenciája ezzel megegyezik, a kölcsönhatás révén jelentősen felerösödik az elektromágneses tér intenzitása [75]. A Raman-szórás esetében a fény és a fémfelület, valamint az ezt körülvevő közeg jellemzőitől függően a gerjesztő, a szórt vagy mindkét fény elektromágneses terének erősítésére sor kerülhet [76]. SERS-erősítés létrejöhet dielektrikumok és félvezetők közremüködésével is, azonban ilyenkor jóval kisebb az erősítés mértéke és mechanizmusa is összetettebb [77].

A plazmonikus felületerősítés hátterének megértéséhez célszerü röviden áttekinteni a fémek optikai tulajdonságait. A SERS szempontjából fontos fémek - arany és ezüst - és hullámhossztartományok - vörös és közeli infravörös - esetében erre kellöen pontos a Drude-féle megközelítés [78].

A tömbi anyagok optikai tulajdonságait az $\varepsilon\left(\omega_{f}\right)$ frekvenciafüggő (vagy az ezzel ekvivalens $\varepsilon\left(\lambda_{f}\right)$ hullámhosszfüggő) dielektromos függvény határozza meg. A dielektromos függvényt a törésmutatóval az $n\left(\omega_{f}\right)=\sqrt{\varepsilon\left(\omega_{f}\right)}$ összefüggés kapcsolja össze. Az $\varepsilon\left(\omega_{f}\right)$ a legtöbb anyag esetében komplex mennyiség [79].

A Drude-modell a fémek ionrácsában mozgó delokalizált elektronokat ideális gáznak (vagy, mivel töltött részecskékről van szó, plazmának) tekinti, és a dielektromos függvényre az alábbi összefüggést adja meg [32]:

$$
\varepsilon\left(\omega_{f}\right)=\varepsilon_{\infty}\left(1-\frac{\omega_{p}^{2}}{\omega_{f}^{2}-i \tau_{0} \omega_{f}}\right),
$$

ahol $\varepsilon_{\infty}$ a végtelen nagy frekvenciához tartozó dielektromos állandó, $\tau_{0}$ az elektronoknak az ionokkal és szennyezőkkel való ütközések gyakorisága. Az egyenletben szereplő 


$$
\begin{gathered}
\omega_{p}=\sqrt{\frac{s e^{2}}{m \varepsilon_{0} \varepsilon_{\infty}}} \\
\lambda_{p}=\frac{2 \pi c}{\sqrt{\frac{s e^{2}}{m \varepsilon_{0} \varepsilon_{\infty}}}}
\end{gathered}
$$

a szabadelektron-plazma töltéssürüség-változásának a frekvenciája (és hullámhossza), azaz a plazmonfrekvencia. Az egyenletben $s$ az egységnyi térfogatban található szabadelektronok száma, $m$ pedig azok tömege, $\varepsilon_{0}$ a vákuumbéli dielektromos állandó.

A fenti egyenlet valós és képzetes részeire az alábbi összefüggés adódik [32]:

$$
\begin{gathered}
\operatorname{Re}\left[\varepsilon\left(\omega_{f}\right)\right]=\varepsilon_{\infty}\left(1-\frac{\omega_{p}^{2}}{\omega_{f}^{2}-\tau_{0}^{2}}\right) \\
\operatorname{Im}\left[\varepsilon\left(\omega_{f}\right)\right]=\frac{\varepsilon_{\infty} \omega_{p}^{2} \tau_{0}}{\omega_{f}\left(\omega_{f}^{2}-\tau_{0}^{2}\right)} .
\end{gathered}
$$

A $\tau_{0} \ll<\omega_{f}$ összefüggést figyelembe véve a plazmonfrekvencia a $\operatorname{Re}\left(\varepsilon\left(\omega_{f}\right)\right) \approx 0$ esetben határozható meg. A fenti összefüggésekböl látható az is, hogy $\omega_{f}<\omega_{p}$ esetén $\operatorname{Re}\left[\varepsilon\left(\omega_{f}\right)\right]<0$. Továbbá, amennyiben $\omega_{f}$ nem túl kicsi, ebben a tartományban az $\operatorname{Im}\left[\varepsilon\left(\omega_{f}\right)\right]$ értéke kicsi. Ezen két feltétel - a dielektromos függvény valós része negatív (és abszolút értéke kellően nagy), a képzetes pedig kicsi - teljesülése esetén az anyagban plazmonrezonancia léphet fel.

A 9. ábra különböző fémek dielektromos függvényeinek valós és képzetes részét mutatja. Látható, hogy a valós rész 400-500 nm fölött mindegyik esetben negatív és folyamatosan csökken a hullámhossz növekedésével. Leggyorsabban az alumínium csökken, ezt követi az ezüst, az arany és a réz hármasa. A képzetes rész viszont pozitív és növekvő tendenciát mutat, bár az ezüst, az arany és a réz esetében az értéke egy nagyságrenddel kisebb, mint a többi fémé. Az ezüst a minimumát $350 \mathrm{~nm}$ körül éri el, és az ottani néhány tizednyi értékről $1200 \mathrm{~nm}$-re kb. 5-re nő. Az arany és a réz esetében a minimum 1 körüli értékkel 650 nm-nél található, majd az ezüsthöz nagyon hasonlóan változik. A fenti összefüggések alapján láthatóan ez a három fém teljesíti leginkább a plazmonrezonancia kialakulásának feltételeit, ami jól egybecseng azzal, hogy a szakirodalom e három fémet tartja a felületerősített Raman-szórásra leginkább alkalmasnak [80]. 

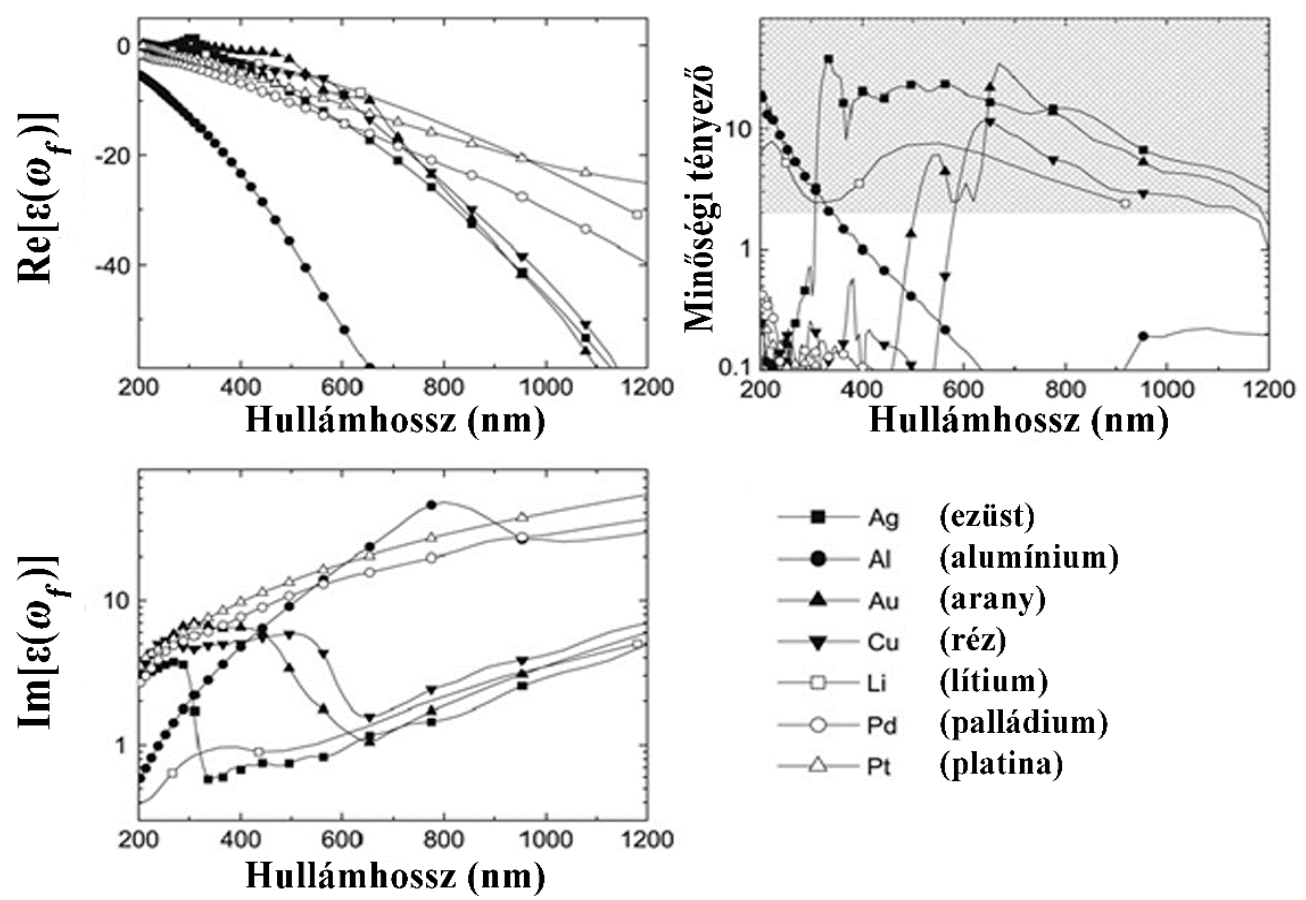

9. ábra: Különbözö fémek $\varepsilon(\lambda)$ dielektromos függvényei

valós (balra fent) és képzetes (balra lent) részének hullámhosszfüggése, valamint minőségi tényezője (a definíciót lásd: (22) egyenlet) [32, 81].

Mint már fentebb említettük, a plazmonrezonancia a fémben található vezetési elektronoknak az elektromágneses tér által gerjesztett oszcillációját jelenti, melyek a fémek felületéhez közel erős tereket eredményez. Ezek alapján a jelenséget két csoportba sorolhatjuk: a felületi valamint a lokalizált plazmonrezonanciára.

Felületi plazmonrezonanciának nevezzük a felületi töltéssürüség olyan oszcillációját, mely hatására a fémfelület és dielektrikum határán a határfelülethez közel erős, de egyben erősen csillapított tér alakul ki (10. ábra (A)), melynek terjedését a $k_{p}$ hullámvektorral jellemezhetjük.
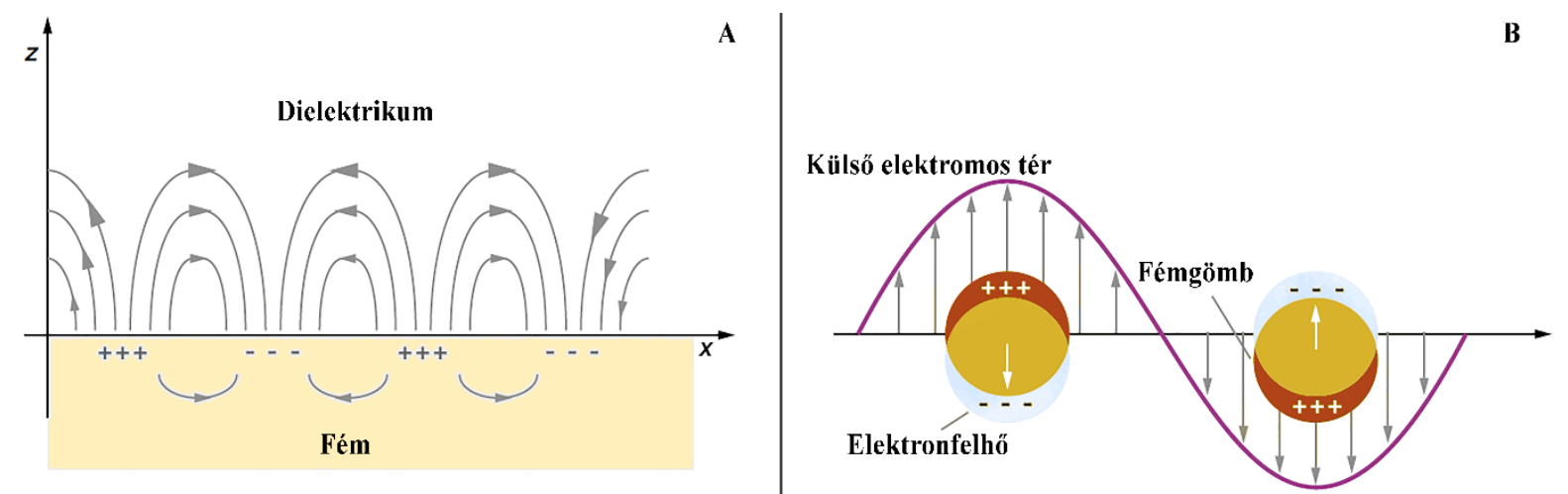

10. ábra: A felületi plazmonrezonancia (A), valamint a lokális plazmonrezonancia (B) mechanizmusai [82]. 
A sík és végtelen felület esetén a külső elektromágneses mező a felület közelében lévő nagyon vékony rétegben (néhány vagy néhány tíz $\mathrm{nm}$ ) gerjeszti az elektronokat. Az $\varepsilon\left(\omega_{f}\right)$, dielektromos függvénnyel leírható fémfelület és $\varepsilon_{M}\left(\omega_{f}\right)$ dielektromos függvénnyel rendelkező szigetelő közeg között felületi elektromágneses hullám alakulhat ki. Ez a hullám egy longitudinális töltéssürüség-hullám (ellentétben a transzverzális fényhullámokkal). A töltéshullámot polaritonhullámnak nevezzük, amely a felszíni plazmonhullám által előidézett elektromágneses hullámhoz kapcsolható. Ez az oka annak, hogy a felületi plazmonrezonanciát néha felszíni plazmon-polaritonnak is hívják. Ennek terjedését a következő diszperziós összefüggés jellemzi:

$$
k_{x}=\frac{\omega_{f}}{c} \sqrt{\frac{\varepsilon\left(\omega_{f}\right) \varepsilon_{M}\left(\omega_{f}\right)}{\varepsilon\left(\omega_{f}\right)+\varepsilon_{M}\left(\omega_{f}\right)}}
$$

Itt a négyzetgyök alatti érték nagyobb, mint a fémeknél, ezért a plazmonhullám hullámvektora nagyobb, mint a szabad térben haladó hullámé. Következésképpen, a felületi plazmonok csak speciális feltételek esetén alakulnak ki. Erre a legelterjedtebb módszer az úgynevezett Kretschmann-konfigurációjú prizma alkalmazása [83].

A lokális plazmonrezonancia kialakulásának egyszerü példája a külső elektromágneses térbe helyezett, $\varepsilon_{M}\left(\omega_{f}\right)$ dielektromos állandóval rendelkező közegben található, a hullámhossznál jóval kisebb méretü, $\varepsilon\left(\omega_{f}\right)$ dielektromos függvénnyel rendelkező fémgömb (10. ábra (B)). Ennek belsejében az $E_{0}$ külső tér által gerjesztett elektromos tér $E_{B}$ nagyságát a következő összefüggés határozza meg [84]:

$$
E_{B}=\frac{3 \varepsilon_{M}\left(\omega_{f}\right)}{\varepsilon\left(\omega_{f}\right)-2 \varepsilon_{M}\left(\omega_{f}\right)} E_{0}
$$

Látható, hogy amennyiben a nevező értéke a nullához közelítene, a külső tér által gerjesztett belső $E_{B}$ térerősség jelentősen megnőne, és egyfajta rezonancia lépne fel. A nevező nullához tartásának feltétele: $\varepsilon\left(\omega_{f}\right)=-2 \varepsilon_{M}\left(\omega_{f}\right)$. Amint azt a 9. ábra mutatja, ez a feltétel fémek esetében könnyen teljesíthető, és meghatározott hullámhosszakon lokalizált felületi plazmonrezonancia lép fel, ami a külső tér abszorpciójának megnövekedésével jár. Levegőben található $25 \mathrm{~nm}$-es ezüst nanogömb esetében ez például kb. $345 \mathrm{~nm}$-es hullámhosszon teljesül (lásd a 11. ábra). 


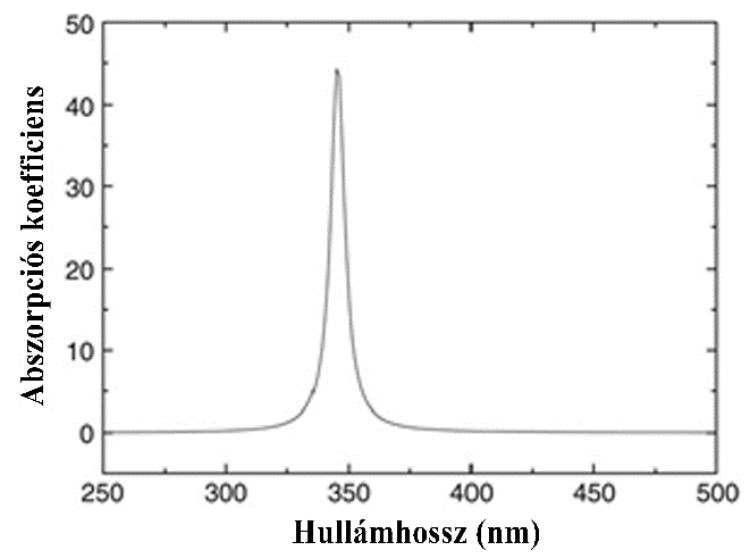

11. ábra: Levegőbe helyezett 25 nm-es ezüst nanogömb abszorpciós együtthatójának hullámhosszfüggése [32].

A rezonanciára megfogalmazott követelmény alapján elmondható, hogy annak teljesülése és a lokális felületi plazmonrezonancia kialakulása, több tényező függvénye: befolyásolja a közeg dielektromos állandója, a fém fajtája, alakja és mérete, több részecske vagy strukturált egység esetén pedig a közöttük fellépő csatolás is jelentős szerepet játszhat. A dielektromos függvény képzetes része szintén fontos paraméter, mivel az optikai abszorpciót jellemzi.

Meg kell említenünk a csatolt plazmonrezonancia jelenségét, amely akkor következik be, amikor két vagy több plazmonikus részecske vagy struktúra között a távolság összemérhető azok átmérőjével. Az egyes részecskék plazmonrezonanciája csatolódhat, és a közös rezonanciaspektrumuk a magasabb hullámhossztartomány felé tolódik el. A spektrum vöröseltolódásának nagysága a részecskék közötti távolságától, valamint a klasztermérettől függ [85, 86]. A csatolt plazmonrezonancia a részecskék közötti elektromos mező több nagyságrenddel való megnövekedésének is forrása lehet. A jelenség tudatos felhasználása a plazmonikus struktúra finomhangolásának egyik effektív módszere.

A lokális felületi plazmonrezonancia erősségének jellemzésére vezették be a minőségi tényezőt:

$$
Q=\frac{\omega_{f}\left(\frac{d\left\{\operatorname{Re}\left[\varepsilon\left(\omega_{f}\right)\right]\right\}}{d \omega_{f}}\right)}{2\left(\operatorname{Im}\left[\varepsilon\left(\omega_{f}\right)\right]\right)^{2}}
$$


Ennek hullámhosszfüggését különböző fémeknél a 9. ábra mutatja. Az ábra besatírozott részéröl leolvasható, hogy a látható és közeli infravörös hullámhossztartományban három fém jöhet szóba a felületerősített Raman-szórás (és más plazmonikus jelenségek) anyagaként: az ezüst, az arany és a réz. A kísérleti tapasztalatok azt mutatják, hogy az ezüst hajlamos a fotooxidációra, ahogy a réz felülete is könnyen oxidálódik, és az arany a legstabilabb. Nemesfém volta ellenére az arany felülete viszonylag egyszerüen funkcionalizálható, így nem véletlenül lett a SERS-anyagok közül a legelterjedtebb. Az elektromágneses tér felületi plazmonrezonancia általi erősítésének jellemzésére vezették be a lokális térintenzitás-erősítési tényezőt (LTIEF), ami azt mutatja, mennyire változik meg az adott elektromágneses tér intenzitása a plazmonikus fémfelület jelenlétében ahhoz képest, amikor az nincs a közegben. Attól függően, hogy az LTIEF értéke nagyobb vagy kisebb egynél, az adott optikai jelenség során a folyamat erősítése vagy gyengítése lép fel. A LTIEF hullámhosszfüggő (vagy frekvenciafüggő) mennyiség, és mivel lokalizált mennyiség, tér adott $\boldsymbol{r}$ pontjában az alábbi összefüggéssel adható meg:

$$
\operatorname{LTIEF}(r, \omega)=\frac{|\vec{E}(r, \omega)|^{2}}{\left|\overrightarrow{E_{0}}(r, \omega)\right|^{2}}
$$

A fény frekvenciájától és a felület tulajdonságaitól függően a plazmonikus felület egyes részei inaktívak maradnak, míg más részeken az elektromos térerősség extrém mértékben megnő. Ezeket a nagy erősítéssel rendelkező területeket informálisan forró pontoknak nevezik a SERS-irodalomban [87 - 89]. Számos kutatás foglalkozik a különböző struktúrák SERSerősítésének vizsgálatával. Kimutatták, hogy a forró pontokban az LTIEF több nagyságrendnyi növekedése rendszerint a plazmonrezonancia erős térbeli lokalizációjával jár [33].

\subsection{A SERS-erősítés értékének elméleti és kísérleti meghatározása}

A SERS-erősítés mértékének meghatározása napjainkban is intenzív viták tárgya. Míg az elméleti megközelítésben ennek definiálása viszonylag egyszerü, a gyakorlati meghatározás a SERS-t befolyásoló tényezők széles köre miatt már sokkal nehezebben egységesíthető. A SERS-erősítés mértékét befolyásolja a gerjesztő fényforrás hullámhossza, polarizációja és beesési szöge; a szórt fény gyüjtésének geometriája és térszöge; a SERS-hordozó jellemzői: anyaga, geometriája, morfológiája; a SERS-hordozóval határos közeg törésmutatója; a kísérlethez használt minta jellemzői: koncentrációja és borítottsága a SERS-felületen, a SERSfelülettől való tényleges távolsága; a SERS-felület és a minta közötti esetleges kölcsönhatások. 
Egy SERS-felület esetében a plazmonrezonancia hullámhossz-tartománya, sokszor jóval kisebb, mint a mért vegyület Raman-sávjainak hullámhossz-tartománya. Mivel a SERSerősítést a gerjesztő fényforrás hullámhosszára hangolják, előfordulhat, hogy a szórt fény esetében az erősítés csak bizonyos Raman-sávokra terjed ki [90].

A korábban bevezetett LTIEF-formalizmusban a SERS-erősítési tényező felírható a beeső és a szórt fény LTIEF-jének szorzataként [32, 64, 91], azaz a teljes elméleti erősítési faktor gerjesztő forrás $\omega_{f}$ és a szórt fotonok $\omega_{s}$ frekvenciáján elérhető erősítések szorzatával egyenlő:

$$
\text { SERS EF }=\operatorname{LTIEF}\left(\omega_{f}\right) \times \operatorname{LTIEF}\left(\omega_{s}\right) .
$$

Ez az egyenlet több egyszerüsítést is tartalmaz, nem veszi figyelembe például a beeső és a szórt terek polarizációinak eltéréseit. Ha feltételezzük, hogy a Raman-sávok frekvenciája nem tér el jelentősen a gerjesztő forrás frekvenciájától (ami nagy Raman-eltolódásoknál nem teljesül [92, 93, 76]), a két LTIEF-tag azonosnak tekinthető, és a (24) felhasználásával megkapjuk a SERS-erősítési tényező leírására használt legegyszerűbb modellt, az úgynevezett $|\mathrm{E}|{ }^{4}$ közelítést:

$$
S E R S E F \sim L T I E F^{2}\left(\omega_{f}\right)=E(r)^{4} / E_{0}(r)^{4}
$$

Bár (25) számos egyszerüsítést tartalmaz, sokszor meglepően pontos becslést ad a SERS-erősítésről. A SERS-erősítési tényezők kísérleti meghatározásánál a különböző kísérletek eredményeit összegezve fontos követelményként határozták meg, hogy mindig a valódi erősítést kell meghatározni, azaz ugyanazon minta normál Raman-szórását kell összehasonlítani a megváltozott körülmények során kapott szórással. Ezen követelmény mellőzése okozta az óriási SERS-erősítések $\left(10^{15}\right)$ megjelenését a szakirodalomban [76].

A SERS-erősítés jellemzésére 3 fő kvantitatív mennyiséget vezettek be: ezek az EMEF -egymolekula-erősítési tényező; a NEF - normalizált erősítési tényező; valamint az $\mathrm{AEF}$ - analitikai erősítési tényező.

Ezen mennyiségek használata függ a SERS-kísérlet jellemzőitől. A nagyon kis koncentrációjú minták vizsgálatakor - egymolekulás méréseknél - használt EMEF az alábbi egyenlet szerint határozható meg:

$$
E M E F=\frac{I_{S E R S}^{M}}{I_{R S}^{M}},
$$

ahol $I_{S E R S}^{M}$ a vizsgált molekula SERS-intenzitása, és $I_{R S}^{M}$ pedig ugyanazon minta esetében a molekula normál Raman-intenzitása. 
A legszélesebb körben használt NEF - normalizált SERS-erösítési tényezőt a következő egyenlet definiálja:

$$
N E F=\frac{N_{R S} \cdot I_{S E R S}}{N_{S E R S} \cdot I_{R S}},
$$

ahol $N_{\text {SERS }}$ a SERS-folyamatban résztvevő molekulák száma, ami rendszerint a felületre abszorbeálódott molekulák számával egyenlő, $N_{R S}$ a hagyományos Raman-folyamatban résztvevő molekulák száma, ami a gerjesztett térfogatban lévő molekulák számával egyenlö. A megközelítés egyik gyengéje, hogy a legtöbb folyadékban végzett tömbi mérés során a tömbi térfogatban jelen lévő molekulák normál Raman-jele is hozzáadódik a felületen adszorbeáltak SERS-jeléhez.

Abban az esetben, ha vizsgált mintaként olyan oldatot használunk, ahol a felületen abszorbeálódott molekulák száma nagyságrendileg összemérhető a normál Raman-szórásban résztvevő molekulák számával, egy egyszerüsítést eszközölhetünk. Vegyünk egy $C_{R S}$ koncentrációjú oldatot, amely gerjesztés hatására $I_{R S}$ Raman-jelet eredményez. Azonos kísérleti, és ugyanazon előkészítési körülmények között ugyanaz az anyag $C_{\text {SERS koncentráció }}$ mellett a SERS-hordozón ISERS intenzitással sugároz. Az analitikai erősítési tényezőt (AEF) az alábbi módon definiálhatjuk:

$$
A E F=\frac{C_{R S} \cdot I_{S E R S}}{C_{S E R S} \cdot I_{R S}^{M}} .
$$

Bár a fenti definíciók jól meghatározzák a SERS-erősítés meghatározásának módját, a tényleges mérések során különösen a koncentrációkat nehéz pontosan meghatározni. Éppen ezért sokszor célszerübb összehasonlító méréseket végezni, melyek célja nem az abszolút SERS-erősítési tényező, hanem a különböző minták azonos módon mért SERS-erősítései összehasonlításának meghatározása.

\subsection{Az időtartománybeli véges differenciák módszere}

A SERS-jelenség közvetlen modellezése meglehetősen bonyolult, kihívásokkal teli (mint a legtöbb nemlineáris folyamatnál általában). A SERS-felületek jellemzésére gyakran használnak numerikus módszereket. Az egyik legelterjedtebb ilyen módszer az időtartománybeli véges differenciák (Finite Difference Tme Domain, FDTD) módszere, melyet Kane Yee dolgozott ki 1966-ban [35], segítségével meghatározható a vizsgált modell elektromágneses téreloszlása. A SERS EF a legtöbb esetben a korábban bemutatott (25) képlettel definiálják, ahol $\mathrm{E}$ a helyi maximális elektromos mező, és $\mathrm{E}_{0}$ a bemeneti forrás 
elektromos mezőjének amplitúdója [94], így a módszer alkalmas a felületerősítés elméleti meghatározására.

Az eljárást széles körben használják a Maxwell-egyenletek összetett geometriákon való megoldására az elektromágnesesség és a fotonika területén. A vizsgálni kívánt térfogatot a geometriának megfelelően, egy úgynevezett térháló segítségével primitív cellákra (Yeecellákra) kell osztani. Nyilvánvaló, hogy egy kisebb háló használata a tér felosztásához pontosabb képet ad a vizsgált objektumról, de jelentősen megnöveli a modellezéshez szükséges erőforrásokat is.

A módszer a térkomponenseknek a diszkrét térbeli és időbeli rácscellákon való megoldásán alapszik, ahol az elektromos komponens a Yee-cella élein, a mágneses pedig a cella oldalain van elhelyezve (12. ábra). Ezen felül az FDTD időtartománybeli technika is, tehát $\vec{E}(\mathrm{t})$ és $\vec{H}(\mathrm{t})$ értékét is megadja. Az FDTD-számítások során a kapott eredmények automatikusan interpolálódnak az egyes rácspontokra [95].

Az FDTD nem mágneses anyagokban oldja meg a Maxwell-egyenleteket:

$$
\begin{gathered}
\frac{\delta D}{\delta t}=\nabla \times H \\
D(\omega)=\varepsilon_{0} \varepsilon_{r}(\omega) \times E(\omega) \\
\frac{\delta H}{\delta t}=-\frac{1}{\mu_{0}} \nabla \times E
\end{gathered}
$$

ahol $\vec{H}, \vec{E}$ és $\vec{D}$ a mágneses, elektromos és eltolási mezők, $\varepsilon$ és $\mu_{0}$ a komplex relatív dielektromos állandó és a mágneses permeabilitási együttható.

Három dimenzióban a Maxwell-egyenletek hat elektromágneses mezőkomponenst tartalmaznak. Ha feltételezzük, hogy a szerkezet végtelen a $z$-irányban, és a mezök függetlenek a $z$-től, a Maxwell-egyenletek két független egyenletcsoportra bonthatók, amelyek megoldhatók csak az xy-síkban, ami megadja a transzverzális elektromos (TE) és a transzverzális mágneses egyenleteket (TM). Ezt követően az $E_{x}, E_{y}$ és $H_{z}$ komponensekkel megoldhatók a TEegyenletek, $H_{x}, H_{y}$ és $E_{z}$ segítségével pedig a TM-egyenletek. 
Primitív cella

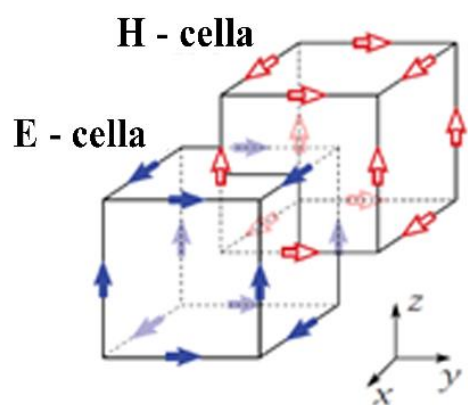

Elektromos mező

Mágneses mező

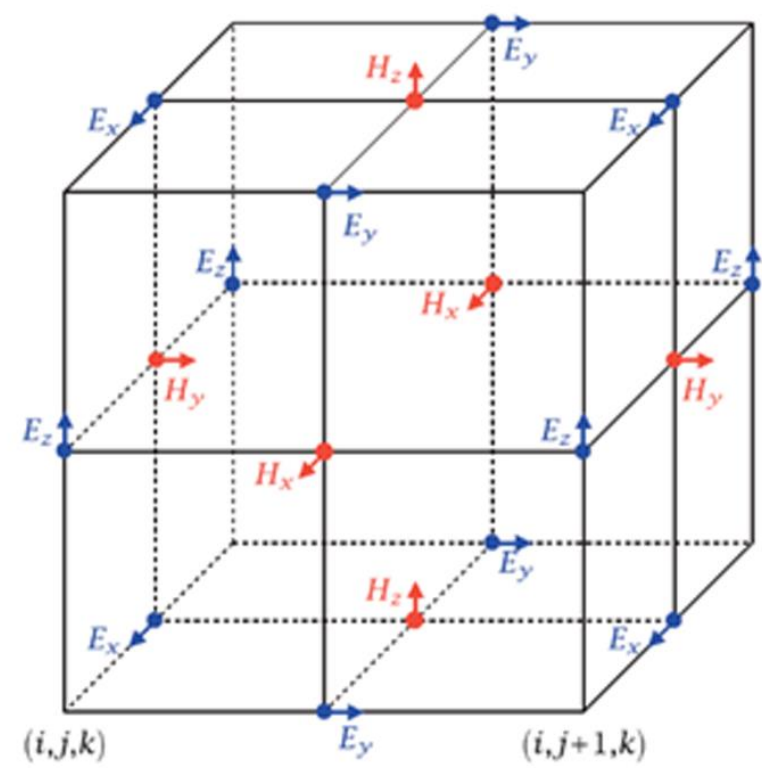

12. ábra: Az FDTD módszer által használt primitív cella - az elektromos komponens a cella élein, a mágneses pedig a cella oldalain van elhelyezve [96]

$$
\begin{gathered}
\frac{\delta E_{z}}{\delta y}-\frac{\delta E_{y}}{\delta z}=-\mu_{0} \frac{\delta H_{x}}{\delta t} \\
\frac{\delta E_{x}}{\delta z}-\frac{\delta E_{z}}{\delta x}=-\mu_{0} \frac{\delta H_{y}}{\delta t} \\
\frac{\delta E_{y}}{\delta x}-\frac{\delta E_{x}}{\delta y}=-\mu_{0} \frac{\delta H_{z}}{\delta t} \\
\frac{\delta H_{z}}{\delta y}-\frac{\delta H_{y}}{\delta z}=-\mu_{0} \frac{\delta E_{x}}{\delta t} \\
\frac{\delta H_{x}}{\delta z}-\frac{\delta H_{z}}{\delta x}=-\mu_{0} \frac{\delta E_{y}}{\delta t} \\
\frac{\delta H_{y}}{\delta x}-\frac{\delta H_{x}}{\delta y}=-\mu_{0} \frac{\delta E_{z}}{\delta t}
\end{gathered}
$$

Ha az $f(x, y, z, t)$ függvény az elektromos vagy mágneses mezöt írja le a koordinátarendszerben, az a középső differencia közelítéssel időben és térben is diszkretizálható:

$$
\begin{aligned}
& \left.\frac{\delta f(x, y, z, t)}{\delta x}\right|_{x=i \Delta x} \approx \frac{f^{n}(i+0.5, j, k)-f^{n}(i-0.5, j, k)}{\Delta x} \\
& \left.\frac{\delta f(x, y, z, t)}{\delta y}\right|_{y=j \Delta y} \approx \frac{f^{n}(i, j+0.5, k)-f^{n}(i, j-0.5, k)}{\Delta y} \\
& \left.\frac{\delta f(x, y, z, t)}{\delta z}\right|_{z=k \Delta z} \approx \frac{f^{n}(i, j, k+0.5)-f^{n}(i, j, k-0.5)}{\Delta z}
\end{aligned}
$$




$$
\left.\frac{\delta f(x, y, z, t)}{\delta t}\right|_{t=n \Delta t} \approx \frac{f^{n+0.5}(i, j, k)-f^{n-0.5}(i, j, k)}{\Delta t} .
$$

Így a tér minden pontjában meghatározhatók az elektromos és a mágneses mezők. SERSerősítés modellezésekor az alábbi paramétereket kell megadni [36]:

- A modellezni kívánt fizikai struktúra - a SERS-hordozó nanorészecske vagy felület geometriájának és méreteinek meghatározása.

- A modellezett térrész és a határfeltételek - a modellezett térfogatnak tartalmaznia kell a SERS-hordozót. Periodikus szerkezeteknél megfelelő határfeltételeket kell megadni.

- A Yee-cella mérete - ennek jóval kisebbnek kell lennie, mint a legkisebb modellezett hullámhossz. Ez a gyakorlatban 1/10 $\lambda_{\min }$ vagy kisebb méretet jelent, de fontos szempont a SERS-hordozó mérete is (ami sokszor 10-100 nm), amivel a Yee-cella méretének legalább összemérhetőnek kell lennie. Az aktív geometria nagy része tíz-száz nanométer tartományban van. Minél kisebb a Yee-cellaméret, annál jobb a számítási eredmény, de annál nagyobb a számítási erőforrásigény is, ezért meg kell találni az optimális egyensúlyt.

- Fényforrás - a beeső fény általában $z$-irányban terjedő síkhullám, $x$-irányú polarizációval.

- A vizsgálni kívánt adatok rögzítésére szolgáló monitorok - azok a síkok, amelyekben vizsgálni kívánjuk a térerősség eloszlását.

- Spektrális válaszfüggvény - a hullámhossztartomány, amelyben a SERS-struktúra válaszfüggvényét (reflexiós spektrumát) modellezni kell. 


\section{ANYAGOK ÉS MÓDSZEREK}

\subsection{Mintakészítés}

Az általam vizsgált SERS-felületek előállítása mikromechanikai technológiák alkalmazásával történt. Ezekkel a mikro- és nanotechnológiában, mikrofluidikában is használt módszerekkel készített mikro-elektromechanikai eszközök (MEMS - microelectromechanical systems), évröl évre egyre nagyobb teret nyernek biológiai és orvosi alkalmazásokban is [97 - 101]. A széleskörüen használt módszerrel precízen kontrollálható a mikroszkopikus felületi struktúrák mérete, alakja és elrendezése, akár 3D szerkezetek kialakítása is megoldható.

A mikromechanikai és mikroelektronikai technológiák alapja a fotolitográfia, melynek mechanizmusát a 13. ábra szemlélteti.

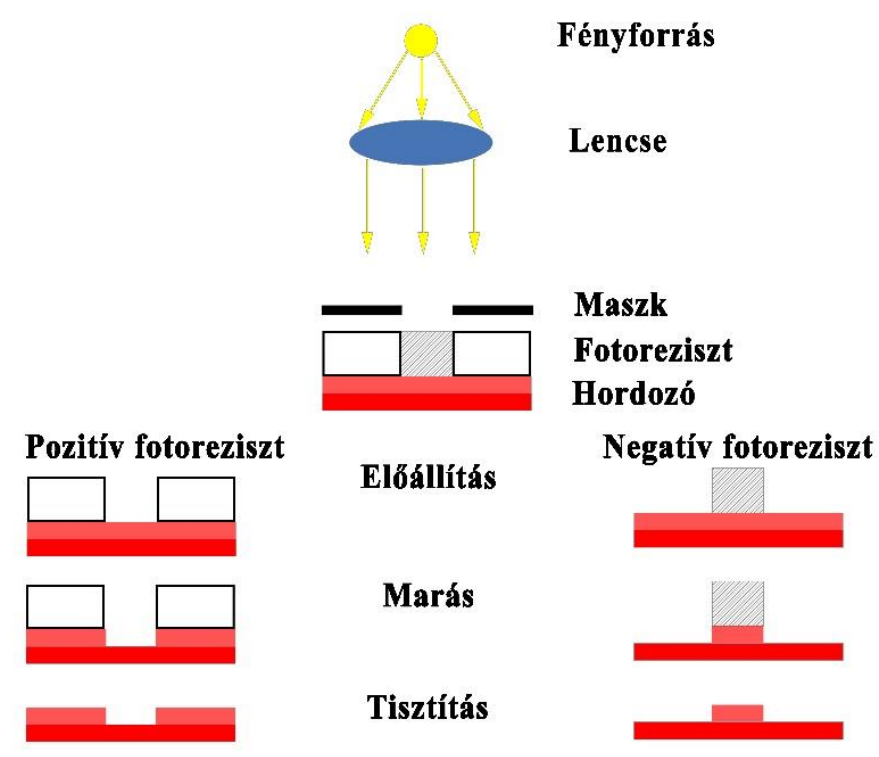

13. ábra: A MEMS szerkezetek elöállitásához használt (pozitív és negativ) fotolitográfia föbb lépései.

A fotolitográfia célja a tervezett felületi struktúráknak megfelelő mintázatú laterális felületi védőréteg létrehozása, ami a felület bizonyos részeit elszigeteli, míg másokat elérhetővé tesz a következő technológiai (jellemzően marási) eljárások számára. A maszkolás általában a felületre felvitt fényérzékeny réteg (fotoreziszt) strukturált megvilágításával történik. A maszkoláshoz pozitív és negatív fotoreziszt is használható: előbbinél a megvilágítatlan, utóbbinál pedig a megvilágított részek maradnak a hordozó felületén. A maszk létrehozása után 
következik a marási lépés, azaz a felületi réteg maszkolatlan részeinek eltávolítása. Az utolsó fázis a tisztítás, amikor a hordozóról eltávolítják a maradék fotorezisztet is [102, 103].

A maszk és mintakészítést az MTA EK Müszaki Fizikai és Anyagtudományi Intézetének MEMS laborjában végeztük. A litográfiás maszk készítése Heidelberg DWL66 maszkgenerátor segítségével történt. Maszkoló rétegként $100-500 \mathrm{~nm}$ vastag $\mathrm{SiO}_{2}$ réteget választottunk le APCVD (atmospheric pressure CVD, atmoszférikus kémiai gőzfázisú leválasztás) technológiával a Si hordozó felületére. A maszkoló oxidréteg szelektív eltávolításához megfelelően strukturált fotoreziszt réteget alakítottunk ki fotolitográfiával, Karl Süss MA 6 maszkillesztő-berendezés segítségével. A szilícium-oxidot hidrogén-fluorid tartalmú marószerrel távolítottuk el a kívánt területekről.

A SERS felületek 3D morfológiájának alakításában fontos szerepet játszik a szilícium marása. A lehetséges, száraz és nedves eljárás közül jelen esetben speciális nedves kémiai marási eljárásokat alkalmaztunk, kihasználva annak anizotrop marási tulajdonságait. A marási rendszereket sebességük irányfüggése alapján két alapvető csoportba oszthatjuk.

Az izotrop nedves marás olyan kémiai reakciókon alapuló folyamat, amelynek sebességeloszlása nem rendelkezik irányfüggéssel (14. ábra). Az izotrop marás esetében a marási sebesség nem, vagy csak minimális mértékben függ a kristálytani orientációtól, és a hordozóban kialakuló mélyedés ennek megfelelően félgömb (tűlyuk-szerü ablakból kiindulva) [104].

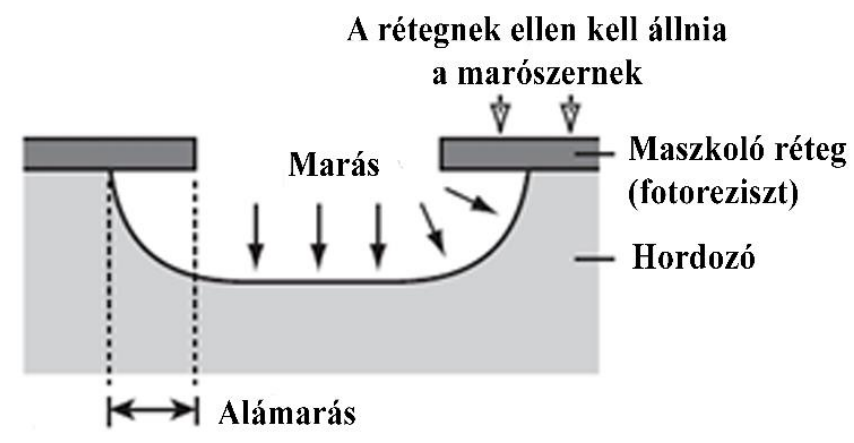

14. ábra: Nedves izotrop marás sematikus ábrázolása [103].

Néhány kristályos anyag azonban lehetővé teszi az ún. irányított anizotrop marás felhasználását. A szilícium egykristály, nagyon effektív anizotrop marást tesz lehetővé alkáli marási rendszerek alkalmazásával, ami mögött a különböző kristálysíkok közötti Si-Si kötések energiájának különbözősége áll [105, 106]: 


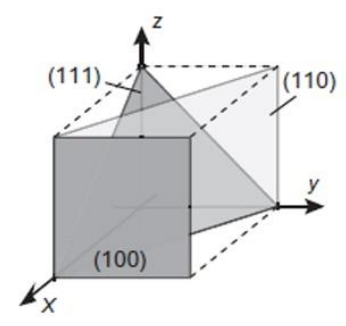

$$
E_{\sigma}^{S i-S i}(111) \gg E_{\sigma}^{S i-S i}(100) ;>E_{\sigma}^{S i-S i}(110) .
$$

15. ábra: A Si kristálysíkjai a megfelelö Miller-indexekkel, valamint a kötési energiák közötti összefüggés [103, 107].

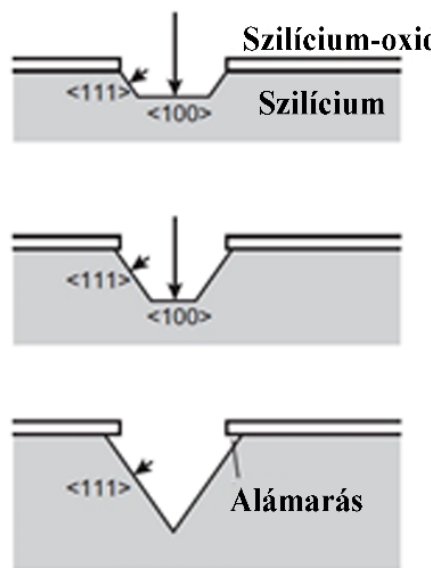

(A) (100) kristálytani

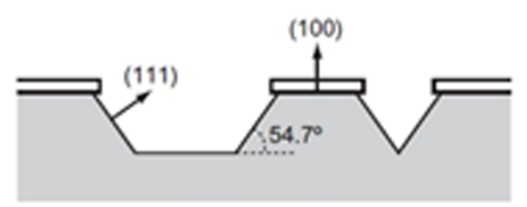

(B) (100) kristálytani

orientáció

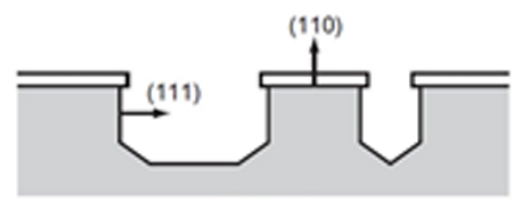

(C) (110) kristálytani orientáció

16. ábra: A Si hordozó anizotrop nedves marása (oldalnézet). (A) A marás 1100$\rangle$ irányban sokkal gyorsabb >150, mint 〈111〉 irányban. (B) Az (100) és (111) felületek 54,7-os szöget zárnak be. (C) Függöleges marás egy (110) orientációjú hordozóban [103].

Ez az anizotrópia leggyakrabban trapéz keresztmetszetü üreget eredményez. A 16. ábra (A) és (B) egy tipikus anizotrop marási folyamatot mutat (100) kristálytani orientációjú hordozón. A marási folyamatot $\langle 100\rangle$ irányban, mind a négy oldalán a (111) felület „határolja be”. A marási folyamat során a (100) felület zsugorodik, és a négy (111) felület a fordított piramisszerkezet csúcsánál találkozik. Figyelembe véve a (100 ) felület és a (111) felület közötti 54,7º-os szöget, nagyjából megbecsülhető a kimart üreg alakja. A 16. ábra (C) pedig egy (110) kristálytani orientációjú hordozón történő marást mutat be a fenti folyamatoknak megfelelően. Számos tanulmányt készítettek az anizotrop szilíciummarás általános eseteinek elemzésére [105, 108]. A marás során fontos a protokollok pontos betartása, nehogy a minta túlmarása vagy épp ellenkezőleg, a „kinyílásának” elmaradása következzen be [109]. 
A SERS-hordozók kialakításakor $\mathrm{SiO}_{2}$ marása pufferelt $\mathrm{HF}$ oldatban történt, melyben a $\mathrm{NH}_{4} \mathrm{~F}$, mint puffer, állandóan tartja az oldat pH értékét, és ezzel a HF koncentrációt.

$$
\mathrm{SiO}_{2}+4 \mathrm{HF}+2 \mathrm{NH}_{4} \mathrm{~F} \rightarrow\left(\mathrm{NH}_{4}\right)_{2} \mathrm{SiF}_{6}+\mathrm{H}_{2} \mathrm{O}
$$

$\mathrm{Az}$ Si izotrop marására a $\mathrm{HF} / \mathrm{HNO}_{3}$ rendszert használatával történt, melynek marási mechanizmusa a következő [110 - 112] :

(1) $\mathrm{NO}_{2}$ képzödése

$$
\mathrm{HNO}_{2}+\mathrm{HNO}_{3} \rightarrow 2 \mathrm{NO}_{2}+\mathrm{H}_{2} \mathrm{O}
$$

(2) $\mathrm{Si} \mathrm{NO}_{2}$ általi oxidációja

$$
2 \mathrm{NO}_{2}+\mathrm{Si} \rightarrow \mathrm{Si}^{2+}+2 \mathrm{NO}_{2}^{-}
$$

(3) $\mathrm{SiO}_{2}$ képzödés

$$
\mathrm{Si}^{2+}+2(\mathrm{OH})^{-} \rightarrow \mathrm{SiO}_{2}+\mathrm{H}_{2}
$$

(4) $\mathrm{SiO}_{2}$ marása

$$
\mathrm{SiO}_{2}+6 \mathrm{HF} \rightarrow \mathrm{H}_{2} \mathrm{SiF}_{6}+2 \mathrm{H}_{2} \mathrm{O}
$$

A szilícium anizotrop lúgos marása pedig a következő KOH eljárás szerint történt [112, 113]:

(1) Oxidáció

$$
4 \mathrm{H}_{2} \mathrm{O}+4 \mathrm{e}^{-} \rightarrow 4 \mathrm{OH}^{-}+2 \mathrm{H}_{2}
$$

(2) Redukció

$$
4 \mathrm{H}_{2} \mathrm{O}+4 \mathrm{e}^{-} \rightarrow 4 \mathrm{OH}^{-}+2 \mathrm{H}_{2}
$$

(3) Oldódás

$$
\mathrm{Si}(\mathrm{OH})_{4}+2 \mathrm{OH}^{-} \rightarrow \mathrm{SiO}_{2}(\mathrm{OH})_{2}{ }^{2-}+2 \mathrm{H}_{2} \mathrm{O}
$$

Bruttó reakció

$$
\mathrm{Si}+2 \mathrm{OH}^{-}+2 \mathrm{H}_{2} \mathrm{O} \rightarrow \mathrm{SiO}_{2}(\mathrm{OH})_{2}{ }^{2-}+2 \mathrm{H}_{2}
$$

A technológia lehetőséget ad továbbá a fent bemutatott eljárások ötvözésére is, amely lekerekített élü üregek előállítását is lehetővé teszi (17. ábra).
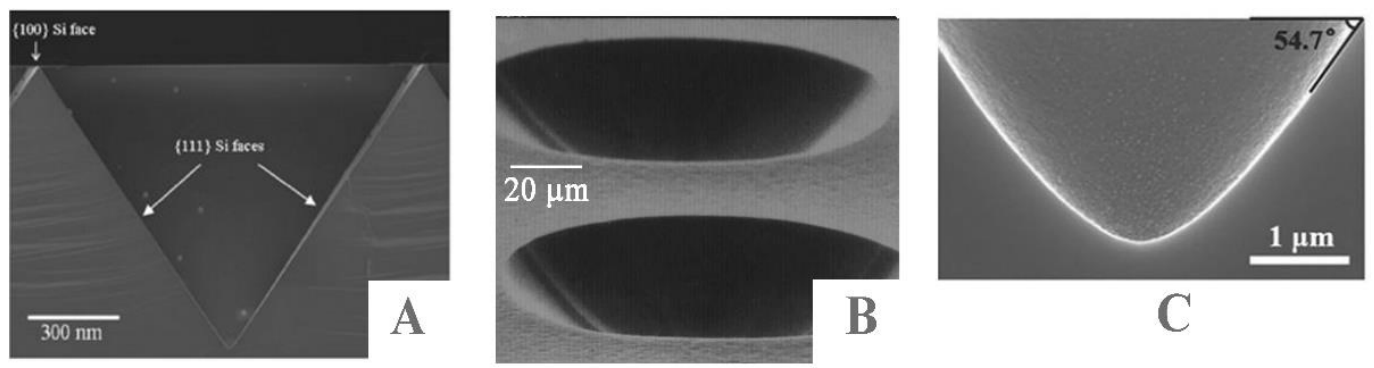

17. ábra: SEM felvételek anizotrop [114] (A), izotrop (B) [115] marásokra és ezek együttes (kevert marás) alkalmazására (C) [116]. 
A perforált SERS szerkezetek elöállítása szintén anizotrop marással történt, de a kiindulási anyag szigetelöre növesztett epitaxiális szilícium réteg volt (SOI - Silicon on insulator). A kívánt vastagságú, (100) orientációjú szilícium réteg $1 \mu \mathrm{m}$ vastagságú $\mathrm{SiO}_{2}$ szigetelőn található. A szilíciumréteg strukturálása ebben az esetben előoldalról, a hordozó tömbi szilícium megmunkálása pedig hátoldalról történhet. A perforált (átfolyásos) SERShordozóknál előbb előoldalról teljesen átmartuk a szilíciumréteget, majd hátoldalról kiindulva eltávolítottuk a tömbi szilíciumot, majd a szigetelő $\mathrm{SiO}_{2}$ réteget (lásd: 18. ábra), ami marásmegállító rétegként is funkcionált. A nagyobb méretü perforált struktúrák esetében 1, 2, 4 és $6 \mu \mathrm{m}$ vastag epitaxiális eszköz-réteggel rendelkező SOI szeletekből (szállító: Siegertwafer $\mathrm{GmbH}$ ) indultunk ki.

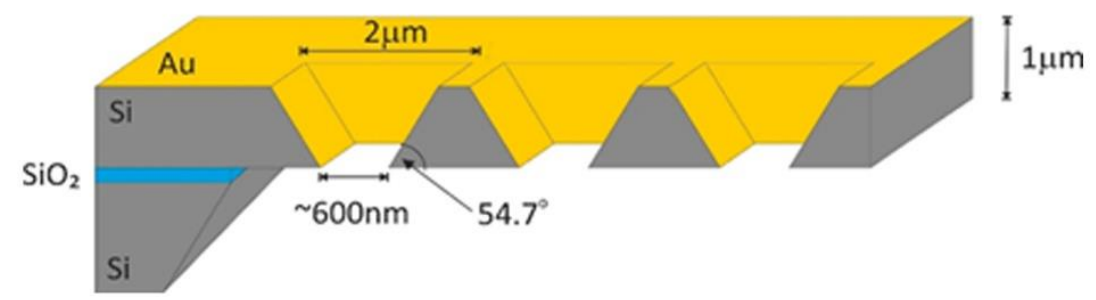

18. ábra: A részecske- és sejtcsapdázásra alkalmas perforált szerkezetek vázlatos geometriája SOI szeletböl kiindulva.

A 3D mikromechanikai technológiákkal előállított hordozókra az 5 nm-es titán adhéziós réteg után egy 100-150 nm vastag aranyréteg került elektronsugaras vákuumgőzöléssel, AJA Orion vákuumporlasztó/gőzölő (AJA International Inc.) készülékben egy vákuumciklusban.

Az aranygömböket tartalmazó inverz piramis SERS-hordozók elöállításához a Corpuscular Inc. (www.microspheres-nanospheres.com) cégtől beszerzett arany nanogömb szuszpenziókat használtam. A négy szuszpenzióban a nanoszemcsék átmérője rendre 50, 100, 200 és $250 \mathrm{~nm}$ volt. A mintakészítés során a szuszpenziót rácseppentettem a SERS-hordozó felületére, majd desztillált vízzel lemostam a felületet, így csak az üregekben csapdázódott arany nanogömbök maradtak a hordozón. A nanorészecskék csapdázását pásztázó elektronmikroszkóppal (SEM) ellenőriztük, de a nagyobb méretü nanogömbök esetében ezt optikai mikroszkóppal is észlelni lehetett (lásd: 19. ábra). 


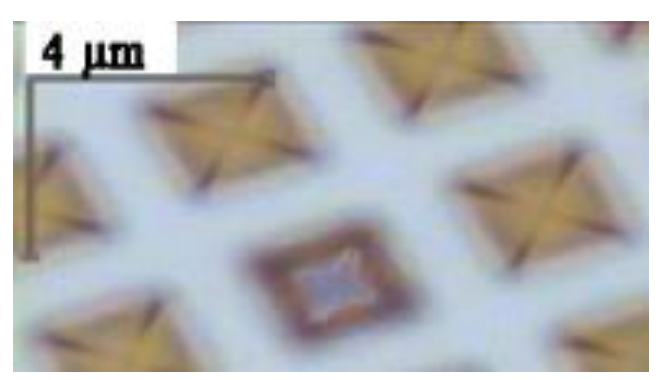

19. ábra: Optikai mikroszkóppal készített felvétel egy inverz piramisban csapdázott részecskéröl.

Az átfolyásos SERS-hordozók tesztelésére kétféle fluoreszcens polisztirol mikrogömböt használtunk. Ezeket a Sigma Aldrich (SA minta) és a Spherotech (ST minta) cégektől szereztük be. A mikrogömbök fö paramétereit az 1. táblázat mutatja.

1. táblázat: Az átfolyásos hordozó tesztelésére használt fluoreszcens mikrogömbök jellemzöi.

\begin{tabular}{|l|c|c|c|c|c|}
\hline Név & Gyártó & $\begin{array}{c}\text { Átmérő, } \\
\boldsymbol{\mu m}\end{array}$ & Anyag & $\begin{array}{c}\text { Gerj. / Em. } \\
\text { hullámhossz, } \mathbf{n m}\end{array}$ & Felületkezelés \\
\hline SA & Sigma Aldrich & $2,0 \pm 0,2$ & Polisztirol /latex & $470 / 505$ & Karboxilozás \\
\hline ST & Spherotech & $1,97 \pm 0,05$ & Polisztirol & $395 / 445$ & - \\
\hline
\end{tabular}

\subsection{Morfológiai jellemzés}

A SERS-hordozók morfológiáját pásztázó elektronmikroszkópiával és fehérfényü interferometriával vizsgáltam. A SEM-mérések egy Zeiss LEO 1540 XB Crossbeam és egy Jeol JSM-25 berendezés használatával készültek, amelyek akár 2 nanométeres felbontásra is képesek. A SEM-vizsgálatok az MTA EK Müszaki Fizikai és Anyagtudományi Intézetében készültek. Mivel a vizsgált SERS-felületeken aranyréteg volt, elektrosztatikus feltöltődéstől nem kellett tartani.

A SERS-hordozók felületének jellemzésére fehérfényü interferometriás felületelemző készüléket is használtam. Az ilyen jellegü berendezés nem széleskörüen elterjedt ezért, röviden bemutatom a készülék müködését. Ez egy többfunkciós, a felület mikrostruktúráját és topográfiáját függőleges (mélységi) szkennelő mérésekkel meghatározni és azokat háromdimenzióban ábrázolni képes berendezés, amellyel a vizsgált felület különböző szempontok szerinti elemzésére is lehetőség van. 


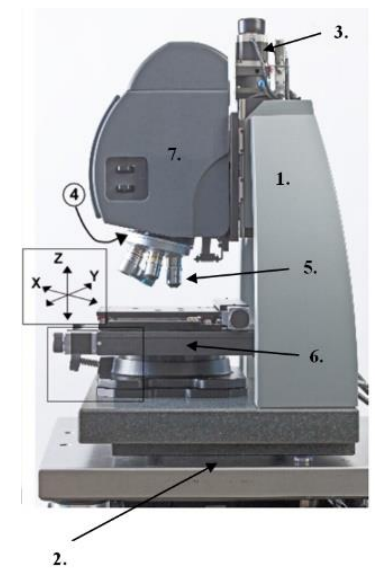

20. ábra: Zygo NewView ${ }^{\mathrm{TM}} 7100$ felületelemzö készülék és annak föbb részegységei:

1 mikroszkópállvány; 2. rezgésmentes asztal; 3. motorizált fókuszvezérlés; 4. forgatható

objektívtartó; 5. 1x, 10x, 50x nagyitású objektivek beépitett Michelson (1x) vagy Mirauinterferométerrel (10x, 50x); 6. motorizáltan mozgatható méröasztal; 7. detektor. [117]

A fehérfényü interferenciás felületelemzést egy Zygo NewView ${ }^{\mathrm{TM}} 7100$ készülékkel végeztem (20. ábra). A berendezésben a fehérfényü LED-fényforrás (középhullámhossza 580 $\mathrm{nm}$, spektrális szélessége $140 \mathrm{~nm}$ ) fénye az interferométert is tartalmazó objektívben osztódik ketté: az egyik fénysugár a mérendő felületre jut, és onnan verődik vissza a detektorba, míg a másik az interferométer referenciaágának végében található tükörről teszi ugyanezt. Amikor a rendszer a mérendő felületre van fókuszálva, a két optikai úthossz megegyezik és a két hullámfront között interferenciajelenség lép fel (lásd: 21. ábra). Mivel a fehérfényü forrás miatt egyszerre több hullámhossz interferál, a detektoron egy csíkrendszer jelenik meg. A precíz fókuszálás nagyon fontos, mert a fehérfény használata miatt a koherenciahossza igen rövid, 3 mikrométer alatti. A mérendő felületről visszaverődő hullámfront a felület egyenetlenségeinek hatására valamennyire torzul, így az interferenciás csíkrendszer a felület topológiájára vonatkozó információkat is tartalmazni fog. A felület jellemzése során a berendezés függőleges irányú szkennelést hajt végre, amit piezoelektromos motor vezérel. Eközben a detektor felületének képpontjai regisztrálják az interferometriás csíkrendszer változásából adódó fényintenzitás-változásokat, és ezeket a szoftver felületi térképekké konvertálja. 


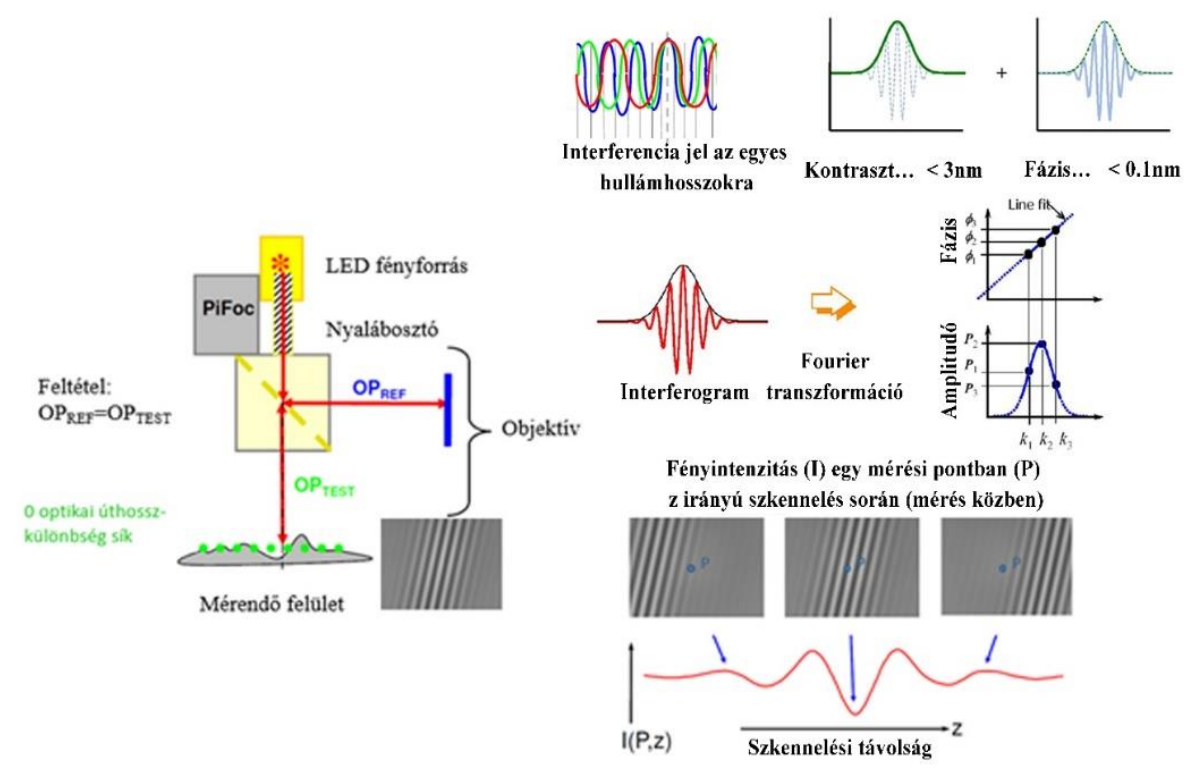

21. ábra: A fehérfényü interferometriás felületelemzö müködési elve.

A mérés időtartama a szkennelési távolságtól (10 $\mu \mathrm{m}-1 \mathrm{~mm})$ függően a néhány másodperctől a néhány perces időtartamig változhat. A mérés végén a szoftver megjeleníti a háromdimenziós felületi térképet, a felület legfőbb paramétereivel együtt. Az interferometriás mérési eljárásnak köszönhetően az a berendezés függőleges irányú felbontása 0,1 nanométer. Oldalirányban ez függ a különböző objektívek nagyításától és a detektor képpontjainak számától, néhány száz nm nanométer lehet.

A mérési adatok feldolgozásakor a berendezés beépített szoftvere mellett az OriginLab Origin 2019 programcsomagot használtam. Ennek beépített Akima Spline illesztését alkalmazva, a beépített szoftvernél pontosabban sikerült ábrázolni a hordozók valós geometriáját [118].

\subsection{Raman-spektroszkópiai vizsgálatok}

A Raman- és SERS-mérésekhez két Raman-spektrométert használtam: egy Leica DM/LM mikroszkóppal egybeépített Renishaw 1000 Raman-rendszert, valamint egy LeicaDM2700 mikroszkóppal egybeépített Renishaw inVia Raman-berendezést (22. ábra). Müködési elvét és felépítését tekintve a két berendezés nagyon hasonló, utóbbi lényegében az előbbi továbbfejlesztett változata, amelybe a technológia fejlődésének köszönhetően motorizált tükörvezérlés és nagyobb érzékenységű és felbontású detektorok kerültek. 

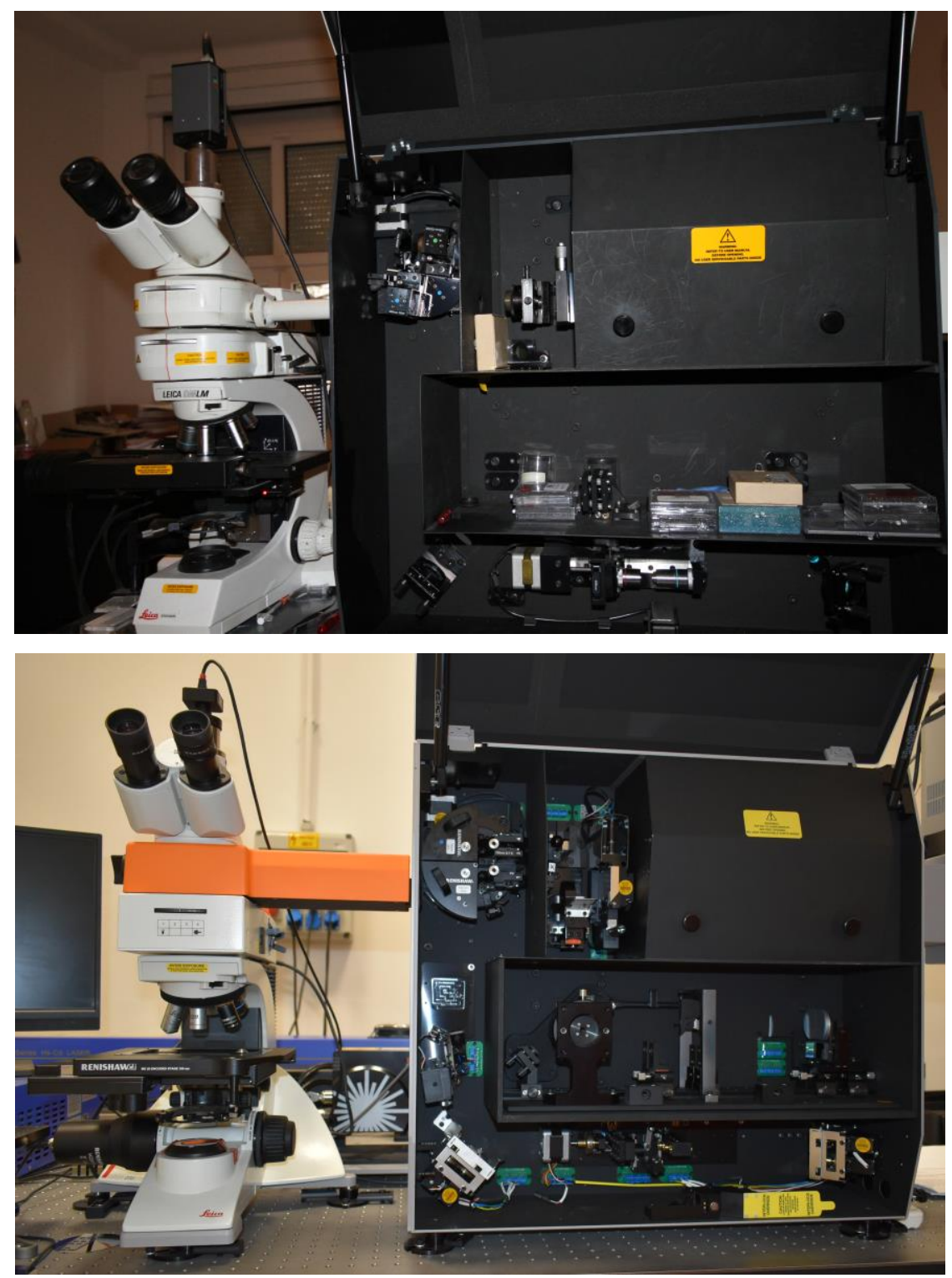

22. ábra: A Renishaw 1000 (fent) és a Renishaw inVia (lent) mikro-Raman-spektrométerek.

A müszerek vázlatos rajzát a Renishaw 1000 mikro-Raman-spektrométer példáján, az egyes részegységek megjelölésével a 23. ábra mutatja. A gerjesztő lézerek a hátoldalon jutnak a készülékbe. Áthaladnak az $A$ szürkeszürőtartón, amely különböző optikai sűrüségü szürkeszürőket tartalmaz a lézerintenzitás csökkentésére. A lézernyaláb ezt követően a $B$ tükrön át egy nyalábtágítóba jut, amely a jobb fókuszálhatóság érdekében megnöveli a nyaláb átméröjét. Ezt követően az E-F tükrök, valamint a gerjesztő lézer hullámhosszán tükörként viselkedő $G$ holografikus szürő a mikroszkópba juttatják a nyalábot, amelynek $U$ tárgyasztalán helyezhetö el a minta. 


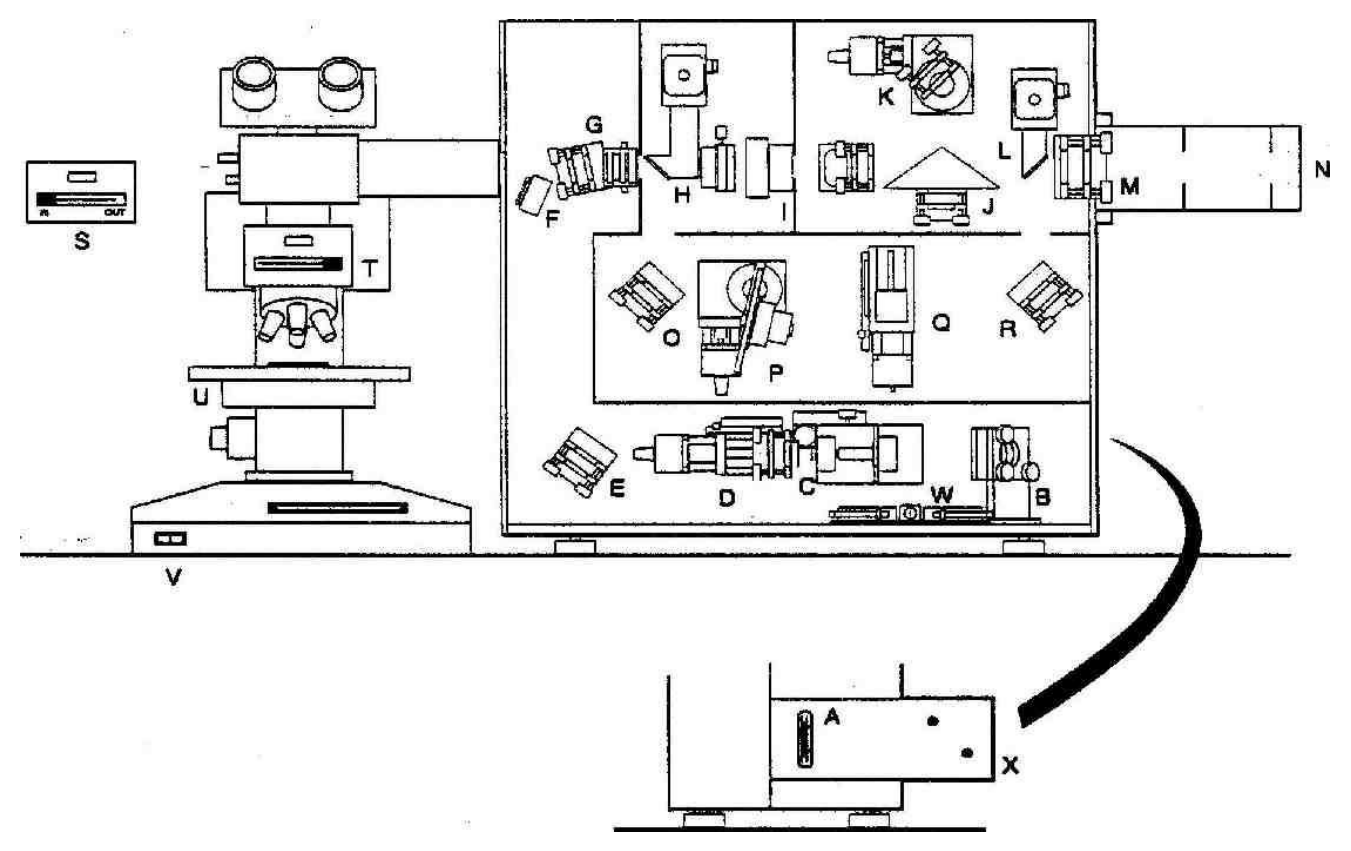

23. ábra: A Renishaw 1000 mikro-Raman-spektrométer felépitése.

A készülék a Raman-spektrumot visszaszórási geometriában méri: az objektíven át a mikroszkópba, majd a készülékbe visszajutó fény a $G$ interferenciás szürőn áthaladva jut a detektoregységbe. A $G$ holografikus szürő speciális jellemzőinek köszönhetően a lézerénél nagyobb hullámhosszakon már átereszti a fényt (így a berendezések a Stokes Raman-szórás mérésére alkalmasak, míg az anti-Stokes folyamatára nem). A detektoregységben a visszaszórt fényt a $H$ lencsén és az $I$ résen való áthaladása után a $J$ tükör juttatja az optikai rácsra. Onnan a spektrálisan felbontott fény az $N$ jelü CCD-detektorba kerül. A mérés helyének megkeresését és dokumentálását egy, a mikroszkóphoz csatlakoztatott kamera segíti, amelynek képe a mérőszoftverben is megjeleníthető, valamint tárolható. A minta mozgatása az objektív alatt a motorizált XYZ-tárgyasztallal történik.

Az optikai rács helyzete a különböző lézerek használatakor más-más pozícióba állhat be, illetve valamennyire a lézerek emissziós hullámhossza is módosulhat, ezért a spektrométert minden mérési sorozat megkezdése előtt kalibráltam a szilícium $520 \mathrm{~cm}^{-1}$ Raman-eltolódásnál található ismert Raman-sávjára.

A Renishaw 1000 és a Renishaw inVia készülékek paramétereit a 2. táblázat foglalja össze. Bár a készülékekhez több gerjesztő fényforrás is elérhető, Raman-méréseimet általában a $785 \mathrm{~nm}$-es gerjesztéssel végeztem. 
2. táblázat: A méréshez használt Raman-eszközök föbb paramétereinek összehasonlitása.

\begin{tabular}{|c|c|c|}
\hline Jellemzö & Renishaw 1000 & Renishaw inVia \\
\hline Gerjesztö fényforrás, nm & 785 és 488 & 532,633 és 785 \\
\hline Detektor & $576 \times 20$ képpontos CCD & 1024×256 képpontos CCD \\
\hline Mikroszkóp objektívek & $5 \mathrm{x}, 20 \mathrm{x}, 50 \mathrm{x}, 100 \mathrm{x}$ & $5 \mathrm{x}, 20 \mathrm{x}, 50 \mathrm{x}, 100 \mathrm{x}$ \\
\hline $\begin{array}{c}\text { Automatikus mintamozgatás } \\
\text { felbontása, } \mu \mathrm{m}\end{array}$ & $\mathrm{XY}$ irányban 0,2 & $\begin{array}{c}\text { XY irányban } 0,1 \\
\text { Z irányban } 0,02\end{array}$ \\
\hline Optikai rács, $1 / \mathrm{mm}$ & 1200 & $1200,1800,2400,3000$ \\
\hline $\begin{array}{c}\text { Maximális elérhető spektrális } \\
\text { felbontás, } \mathrm{cm}^{-1}\end{array}$ & 1,5 & $0,3 *$ \\
\hline
\end{tabular}

*A dolgozatban szereplő mérések esetében $0,7 \mathrm{~cm}^{-1}$

A spektrumok megjelenítését a készülékekhez kötött számítógépeken futó Renishaw WIRE szoftver megfelelő verziói végzik, ahol lehetőség van az expozíciós idő, a lézerteljesítmény, az integrálási idő, mérési tartomány beállítására.

\subsection{A felületerősítés meghatározása}

A SERS-mérések során a felületerősített Raman-szórás mértékének meghatározásához modellanyagként benzofenont használtam. Ezt a vegyületet - több más mellett - a szakirodalomban széles körben használják erre a célra [119 - 121]. A benzofenon szerkezetét és Raman-spektrumát a 24. ábra mutatja.

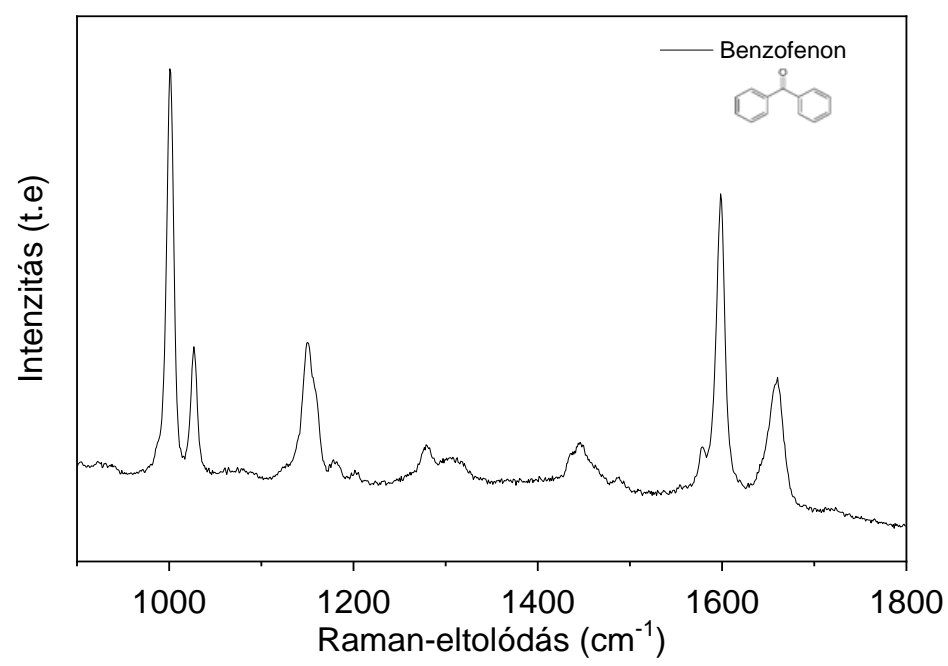

24. ábra: A benzofenon szerkezete és 785 nm-es gerjesztéssel mért Raman-spektruma. 
A molekulának 66 normál rezgési módusa van. A Raman-spektrumban látható fontosabb sávokat és azok hozzárendelését a 3. táblázat tartalmazza [122 - 124].

3. táblázat: A benzofenon karakterisztikus Ramán-sávjainak poziciója és hozzárendelésük.

\begin{tabular}{|c|c|}
\hline Raman-csúcs pozíciója, $\mathbf{c m}^{-\mathbf{1}}$ & Rezgés \\
\hline 1000 & $v C C C$ \\
\hline 1031 & $\delta C C C+\delta C C C$ \\
\hline 1150 & $\delta C H$ \\
\hline 1283 & $\delta C H+\delta C C$ \\
\hline 1600 & $v C C$ \\
\hline 1650 & $v C=C$ \\
\hline
\end{tabular}

Az erősítési tényező meghatározásához benzofenon $1 \mathrm{mM}$-os etanolos oldatát használtam. A jobb összehasonlítás érdekében mindig nagyobb mennyiségű oldatot készítettem, amit tíznél is több minta jellemzésére is fel tudtam használni. A Raman-mérésekhez az oldatot a SERSfelületre cseppentettem, majd a megszáradása után kezdtem el a spektrumok rögzítését. Referenciaként mindig a sík aranyrétegre cseppentett oldaton mért spektrumot használtam. A gyakorlatban ez azt jelentette, hogy a SERS-hordozó strukturált része mellett az aranyozott sík szilíciumfelületre is cseppentettem oldatot, és ennek a spektrumát használtam referenciaként a SERS-erősítés meghatározásához. A cseppentést Eppendorf-pipetta segítségével végeztem, hogy a felületre juttatott mennyiség mindig azonos legyen. A gerjesztő folt átmérője a mintán a mikroszkóphoz tartozó 100X nagyítású objektív (NA-értéke 0,9) használatakor, 785 nm-es gerjesztés mellett $1 \mu \mathrm{m}$ volt. A Raman-berendezés segítségével lehetőség volt a struktúrákról kapott optikai mikroszkópos felvétel és a lézerfolt elhelyezkedésének együttes megjelenítésére, így a gerjesztő nyalábot mindig az inverz struktúra közepére tudtam beállítani. A lézer teljesítményét a beépített szürkeszürők segítségével csökkentettem, hogy a SERS-spektrumok esetében ne telítődjön a detektor. A mintára érkező teljesítmény a normál Raman (referenciamérés) esetében is ugyanez volt, ahogy az integrálási idő is az egyes méréseknél.

\subsection{Modellezés}

Ebben a részben röviden összefoglaltam a modellezési eljárást és a paraméterek beállításait. Az elektromos térerősségnek egy síkhullámmal való kölcsönhatás eredményeként 
kapott eloszlását különböző SERS-felületek - beleértve a perforált és a csapdázott arany nanogömböket tartalmazó szerkezeteket is - a Lumerical FDTD Solutions v.8.15.736 szoftverrel modelleztem. Mivel az általam vizsgált SERS-felületeket üregek mátrixa alkotja, ennek modellezésére a felülettel párhuzamos irányokban periodikus határfeltételeket használtam. Merőleges irányban, a különböző anyagok alkotta rétegek közötti határokon az impedanciák illesztéséhez tökéletesen illeszkedő réteg (PML) határfeltételeket alkalmaztam. A modell felépítését az alábbiakban a 2,2×2,2 $\mu \mathrm{m}$ inverz piramis példáján szeretném bemutatni. Ebben az esetben kiindulásként a fotolitográfiával előállított SERS-felület SEM- képeiből származó méretadatokat használtam. Ezek alapján alkottam meg az inverz piramis geometriáját, hordozó anyagaként a szilíciumot beállítva. Az így kapott felületre újabb, immár aranyból készült réteget illesztettem, melynek vastagságát $150 \mathrm{~nm}$-esre állítottam be. Mivel a SEM-képekből az üregek egymástól való távolsága is meghatározható volt, ezeknek megfelelően határoztam meg a cella méreteit és a periodikus határfeltételeket (25. ábra).

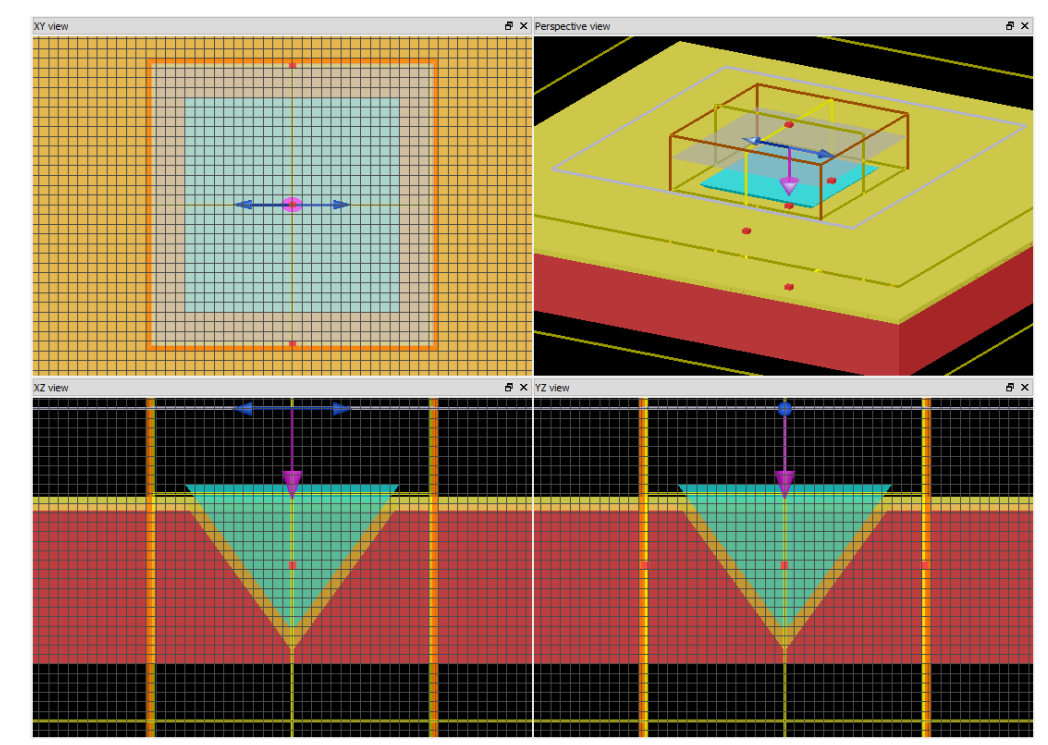

25. ábra: A 2,2×2,2 um alapú inverz piramis alkotta SERS-hordozó FDTD-szimulációhoz épitett modellje.

A modellben használt alapanyagok - a hordozó esetében a szilícium és az aranyréteg optikai paramétereinek és állandóinak megadásához a [81, 125] forrásokból származó, a szoftver által tárolt paramétereket használtam. 
A térerősség ábrázolásához a mintában három monitorsíkot helyeztem el: kettőt a cella szimmetriatengelyei mentén, valamint egyet a felülettel párhuzamosan. További 2 monitor került elhelyezésre, melyek a geometriának megfelelően a visszavert és az átjutó térerősség rögzítésére szolgáltak (26. ábra).

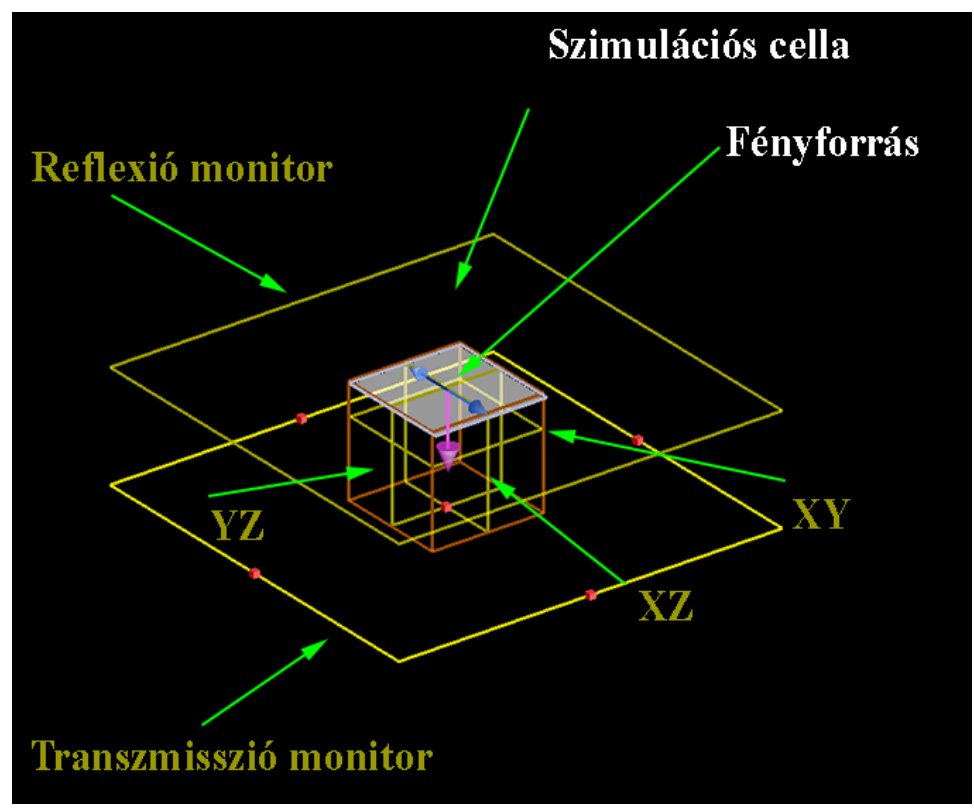

26. ábra: A térerösség-eloszlás mérésére használt monitorsíkok elhelyezkedése.

A modellnél alkalmazott paramétereket több szempontból is validáltam. A PML-feltételek beállításakor fontos paraméter a rétegek száma, amit a számítási teljesítmény optimalizálása érdekében célszerü a modellezés eredményeit még nem befolyásoló legkisebb értékre állítani. A szimulációs cellában elhelyezett időmonitor segítségével megvizsgáltam, mennyi idő alatt cseng le az elektromágneses tér. Ez a modell esetében már 100 fs után megtörténik. Megvizsgáltam azt is, hogy a szimulációs térfogat méretének Z-irányban történő csökkentése mennyire van hatással a modellezés eredményeire - ez a paraméter szintén a számítási kapacitás optimalizálása szempontjából fontos. A térháló illesztése a szoftverben található algoritmus szerint történt, 3-as pontossággal.

\section{EREDMÉNYEK}

Ez a fejezet a kutatómunkám során elért eredményeket tartalmazza. Az első rész különböző morfológiájú periodikus SERS-felületek erősítési jellemzőit mutatja be. Ezt követi a mikroszkopikus objektumok csapdázására alkalmas hordozó fejlesztésének és SERSkarakterisztikáinak ismertetése. Az utolsó rész az aranyfelületű inverz gúlákba helyezett arany nanögömbökön megfigyelhető óriás SERS-erősítéssel foglalkozik. 


\subsection{Különböző morfológiájú SERS-felületek összehasonlító vizsgálata}

A mikroméretű objektumok csapdázására alkalmas üregek különböző geometriákkal rendelkezhetnek. Keresztmetszetük lehet négyzet, téglalap, kör stb. alakú. Mikrogömbök felületének SERS-mérésére a megfelelő méretű, félgömb alakú üreg biztosítja a legnagyobb érintkező felületet, és ugyanez igaz a sejtekre is. A jó SERS-felületeknél viszont fontos paraméter a görbület és annak változása, ezért alkalmaznak például nanoérdességgel és/vagy éles élekkel rendelkező felületeket. A két követelmény közötti optimum megtalálása érdekében célszerü megvizsgálni, mennyire változtatja meg a SERS-erősítési jellemzőket a hordozó méreteinek és különösen a morfológiájának módosítása. Ennek céljából a fotolitográfia és az izotrop/anizotrop marás nyújtotta mintakészítési lehetőségeket felhasználva SERS-hordozókat készítettünk, amelyeken kísérleti SERS-méréseket és modellszámításokat is végeztem.

Az általam vizsgált SERS-hordozók 3 hüvelykes Si-szeleten készültek, egy-egy SERS-chip mérete $10 \times 10 \mathrm{~mm}$ volt, amiből 32 fért el egy szeleten. Egy chipen 2, egyenként $1500 \times 1500 \mu \mathrm{m}^{2}$ területủ aktív tartomány volt, amelyeken 250000 inverz periodikus mintázat volt elhelyezve.

A mintakészítés során 1 mikronos és 2 mikronos alapéllel rendelkező négyzetek mátrixából terveztünk fotolitográfiás maszkot szilíciumhordozóra, majd azokat izotrop, anizotrop és kevert marásnak vetettük alá. A 27. ábra az így készült és már arannyal bevont minták SEM-képeit mutatja. Jól látható, hogy mindegyik esetben sikerült kialakítani az inverz struktúrát, ugyanakkor az izotrop marást is tartalmazó kezeléseknél nem sikerült megőrizni a maszkban megadott méreteket.

Az alábbiakban a $\mathrm{K}$ betüvel jelölt minták tisztán anizotrop marással készültek; a $\mathrm{P}$ betü a tisztán izotrop marsással előállított mintákat jelöli; míg a KP kóddal jelölt minták az anizotrop és izotrop marások együttes alkalmazásával készültek. A betük utáni szám pedig a litográfiás maszk méretére utal.

Az anizotrop marással készült K1 és K2 mintáknál az inverz piramisok jól meghatározott élekkel rendelkeznek. A K2 minta esetében az egyes üregek azonos méretűek (az alap mérete $\sim 2,2 \mu \mathrm{m}$ ), míg a K1 esetében eltérések figyelhetők meg, az egyik piramis alapéle $\sim 0,9-1,1 \mu \mathrm{m}$ között változik. Mindez jól mutatja az álalunk alkalmazott fotolitográfiás technika korlátait (a K1 minta esetében tapasztalt marási hibákat lásd később).

Az izotrop marással elöállított P1 és P2 mintáknál a kezelés mindkét mintánál a szilíciumfelület síkjában kerek üregeket eredményezett. Az üregek alapjának átmérője a P1 és a P2 minta esetében is jelentősen meghaladja az eredeti maszkét, X, Y és az átlók irányában 
rendre $\sim 2,1 \mu \mathrm{m}$ és $\sim 2,9 \mu \mathrm{m}$. A SEM-képeken az üregek belsejében a várakozásoknak megfelelően nem figyelhetők meg éles élek.

A kevert marással készült KP1 és KP2 minták morfológiáján az izotrop és az anizotrop marás jellegzetességei is felismerhetők. A felület síkjában az üregek alapjának az alakja a KP1 minta esetében a sarkokban kerekített négyzet alakú. Itt is megfigyelhető, hogy az egyes üregek nem teljesen azonos méretűek, az alapél mérete $\sim 2,1 \mu \mathrm{m}$ és $\sim 2,3 \mu \mathrm{m}$ között változik. Az alapél mérete jelentősen megnőtt a KP2 minta esetében is, a szomszédos üregek teljesen összenőttek. Az üregek belsejében felismerhetők a piramis élei, de a K1, K2 mintákhoz hasonló éles belső élek nem láthatók.
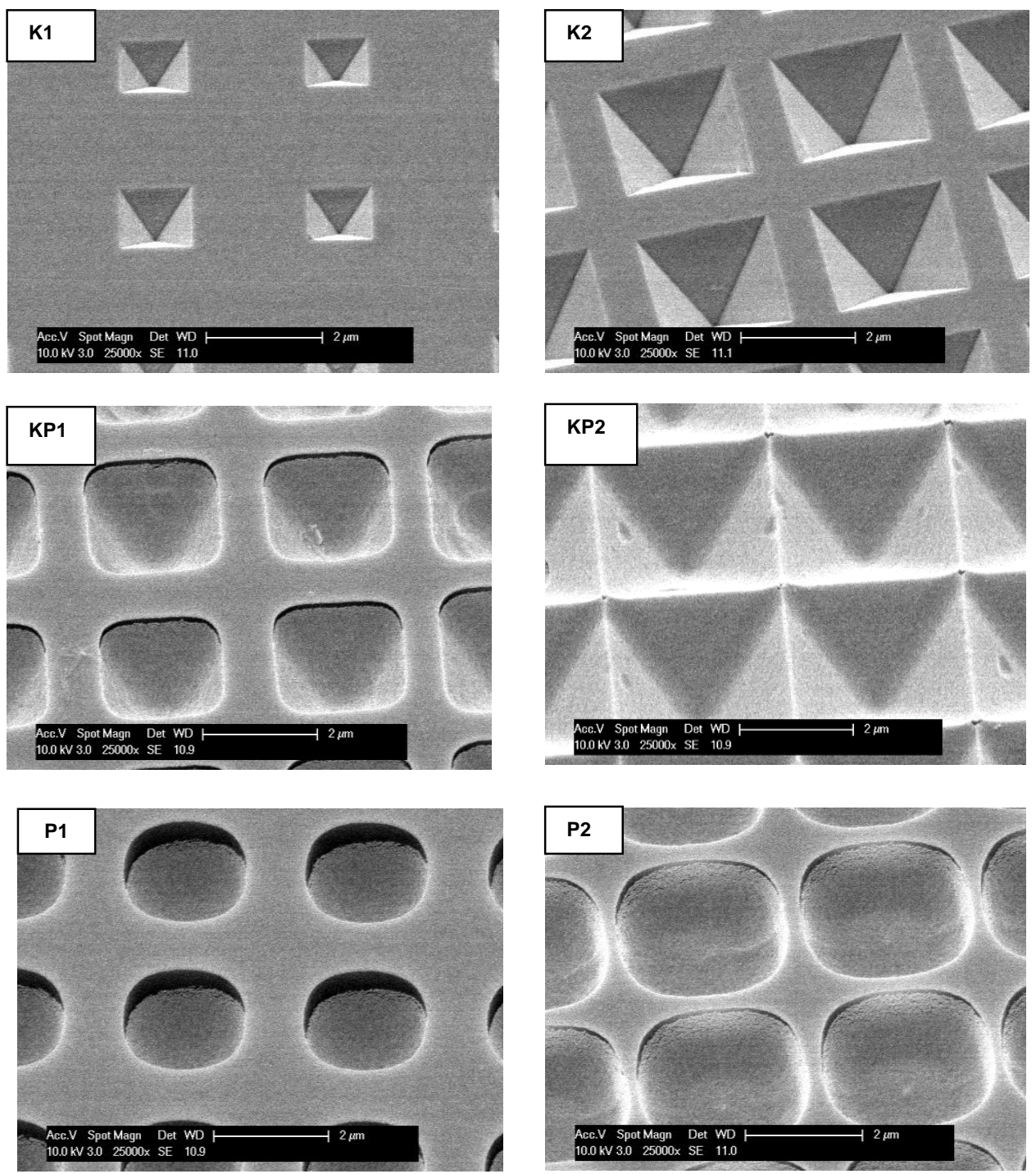

27. ábra: $1 \mu \mathrm{m}$ (bal oldali oszlop) és $2 \mu \mathrm{m}$ (jobb oldali oszlop) fotolitográfiás maszkokkal készült, izotrop (K1 és K2) izotrop+anizotrop (KP1 és KP2) és anizotrop (P1 és P2) marással szilíciumban kialakitott struktúrák SEM-képei. 
Érdemes néhány szót ejteni az $1 \mu \mathrm{m}$ mintáknál tapasztalt marási hibákról. Amint az az alábbi ábrán látható, a maszkban található egyes üregeknél marási hibák jelennek meg, és nem alakul ki üreg a SERS-felületen, aminek oka lehet, hogy a maszk elöhívása nem volt megfelelö, vagy a kémiai folyamat nem indult meg, és a hordozó hibás.

A 28. ábra a K1, KP1 és P1 mintákról készült SEM felvételeket hivatott bemutatni egy olyan területen, ahol jól megfigyelhetőek olyan helyek, ahol nem sikerült a marás, valamint
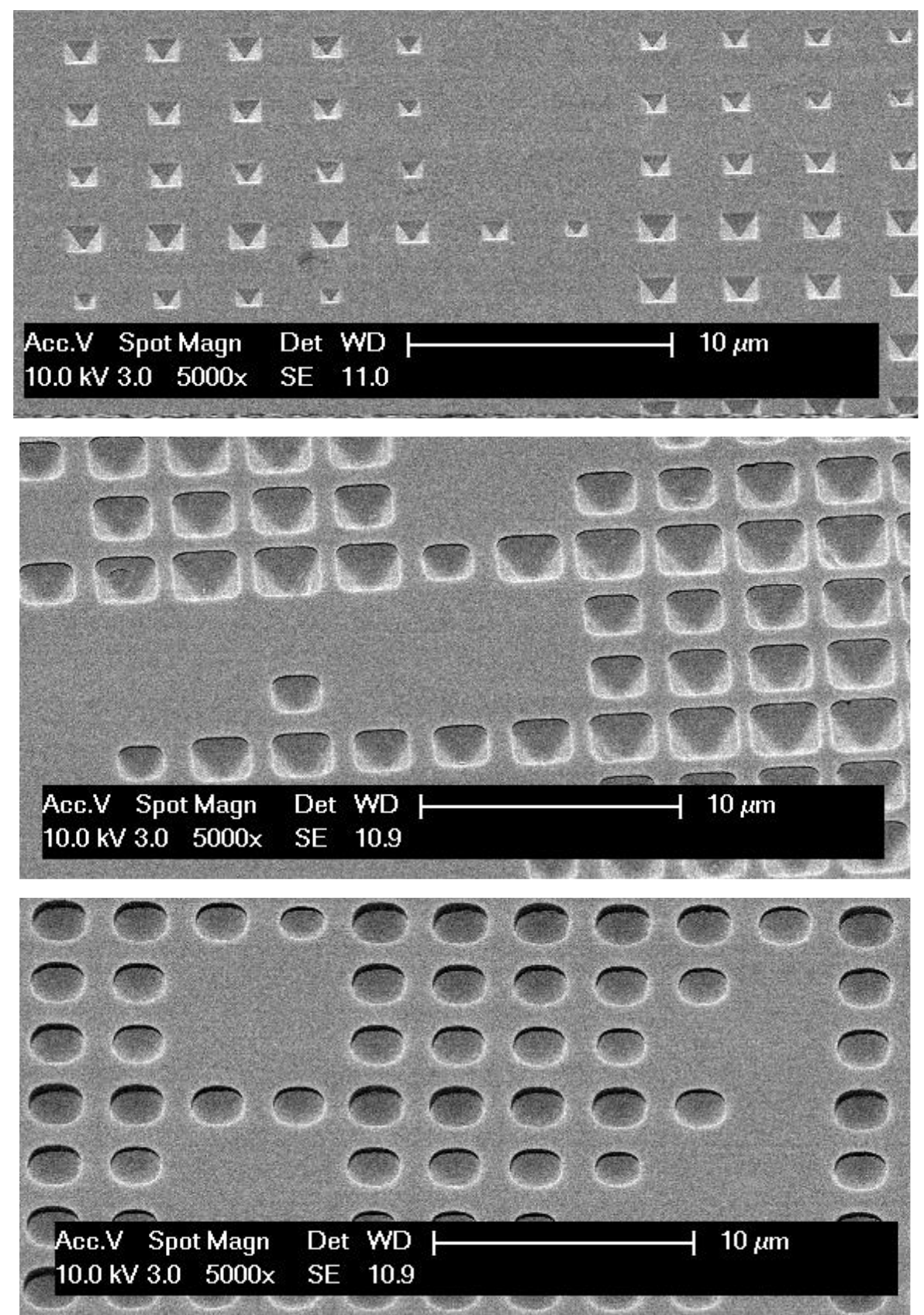

28. ábra: A K1, KP1 és P1 mintáról készült SEM felvétel $5000 X$ nagyitás mellett. A felületen elöforduló marási hibák és a struktúrák méretbeli szórása is látható. 
az egyes mintáknál tapasztalható méretbeli eltérés. A K2, KP2, P2 minták esetében nem volt megfigyelhető az egyes méretek jelentős szórása.

A SERS-hordozók üregeinek morfológiáját fehérfényü interferometriával vizsgáltam. Bár a módszer mikrométer körüli laterális felbontása nem sokkal több, mint az üregek laterális mérete, a szoftver beállításainak finomhangolásával sikerült értékelhető adatokat kapni a mintákról, melyek különösen az üregek belsejére vonatkozóan voltak hasznosak (a hordozó felületéről a SEM-képek részletes információkat adtak). A 29. és 30. ábrákon az egyes SERShordozókról a fehérfényü interferométerrel készített optikai intenzitástérkép, az interferogramokból meghatározott háromdimenziós felületi topológia, valamint a néhány szomszédos üreg középpontján áthaladó felületi profil láthatók.

A 29. ábra intenzitástérképein az $1 \times 1 \mu \mathrm{m}$ alapéllel rendelkező négyzetek alkotta maszkkal készült mindegyik minta felületén periodikus struktúrák figyelhetők meg. Ezek a felületi topológiát mutató képeken is felismerhetők, itt azonban a berendezés laterális felbontásának korlátai miatt mütermékek is előfordulnak (különösen a KP1 mintánál). A K1, KP1 és P1 minták felületi profiljai összhangban vannak az üregek felületére vonatkozóan a SEM-képek alapján levont következtetésekkel. A K1 minta esetében az üregek mélysége 0,70,9 $\mu \mathrm{m}$ között változik, nagy a szórás az inverz piramisok méreteinél, ami jól összecseng az alapélek méreteinek a SEM-képeken megfigyelhető eltéréseivel. A kevert marással készült KP1 minta esetében az üregek mélysége 1,7-1,9 $\mu \mathrm{m}$ között változik (a SEM-képek alapján az alapélek mérete is jóval nagyobb volt, mint a K1 mintáé). Mindegyik üregnél egy törés figyelhető meg a profilokban 0,4-0,5 $\mu$ m mélységben. Az addig ívelt profil jellege megváltozik. Végül a P1 mintánál az üregek mélysége 1,0-1,1 $\mu \mathrm{m}$, és annak profilja jól mutatja az izotrop marás miatti félgömbszerü alakot. 


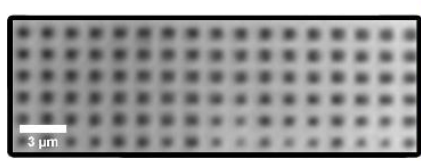

Fehérfény intenzitástérkép

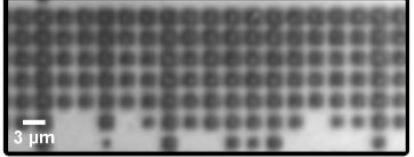

Fehérfény intenzitástérkép

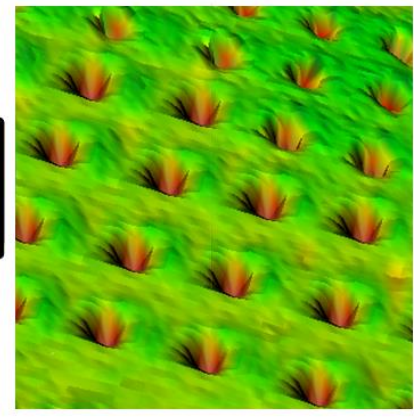

3D nézet

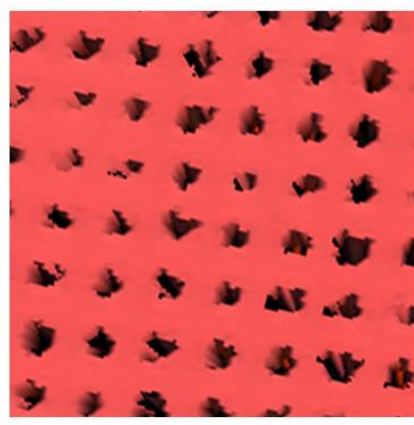

3D nézet

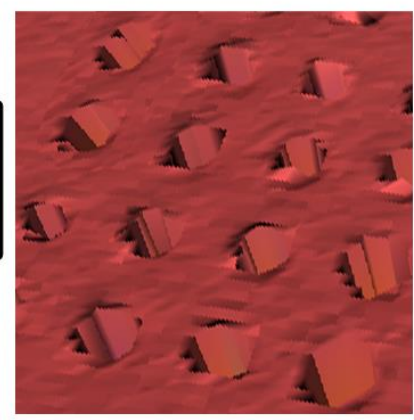

3D nézet
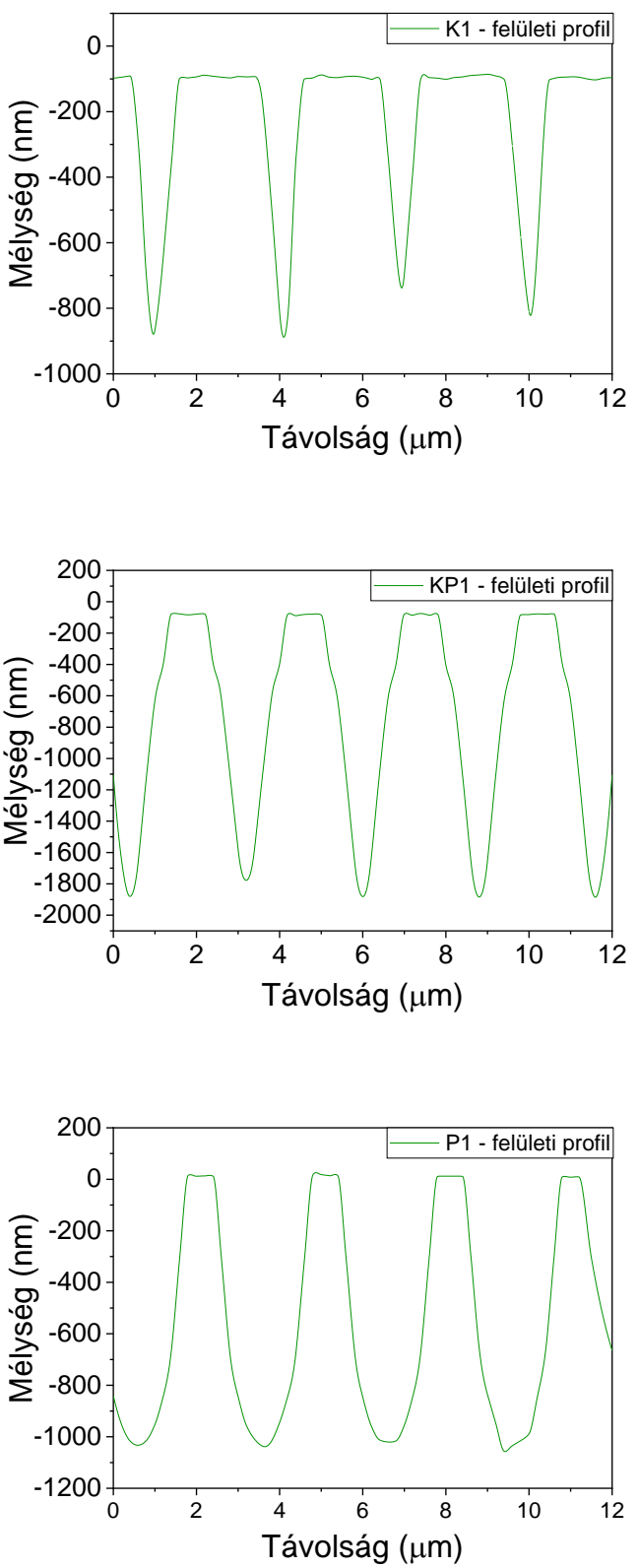

29. ábra: A K1, KP1 és P1 minták fehérfényü interferométerrel készitett intenzitástérképe, az interferogramokból meghatározott háromdimenziós felületi topológia, valamint a néhány szomszédos üreg középpontján áthaladó felületi profil.

A K2, KP2 és P2 mintákon végzett hasonló mérések eredményeit a 30. ábra mutatja. A K1 mintánál az üregek mélysége 1,5 $\mu \mathrm{m}$ körüli, az érték szórása jóval kisebb, mint a K2 minta esetében. A kevert marással készült KP2 mintánál a profil jól mutatja a marásnak a SEM-képen is látott eredményét, azaz az üregek közötti „hézagok” szinte teljes eltűnését. Ebben az esetben a mélység 2,0-2,1 $\mu \mathrm{m}$ körüli, és a KP1 mintához hasonlóan és a profilban itt is megfigyelhetök 
szabálytalanságok, mintha az izotrop és az anizotrop marás is intenzívebb lett volna az üregek bizonyos részein. A P2 mintánál a mélység 1,2 $\mu \mathrm{m}$ körüli, az üregek alakja hasonló a P1 mintáéhoz.
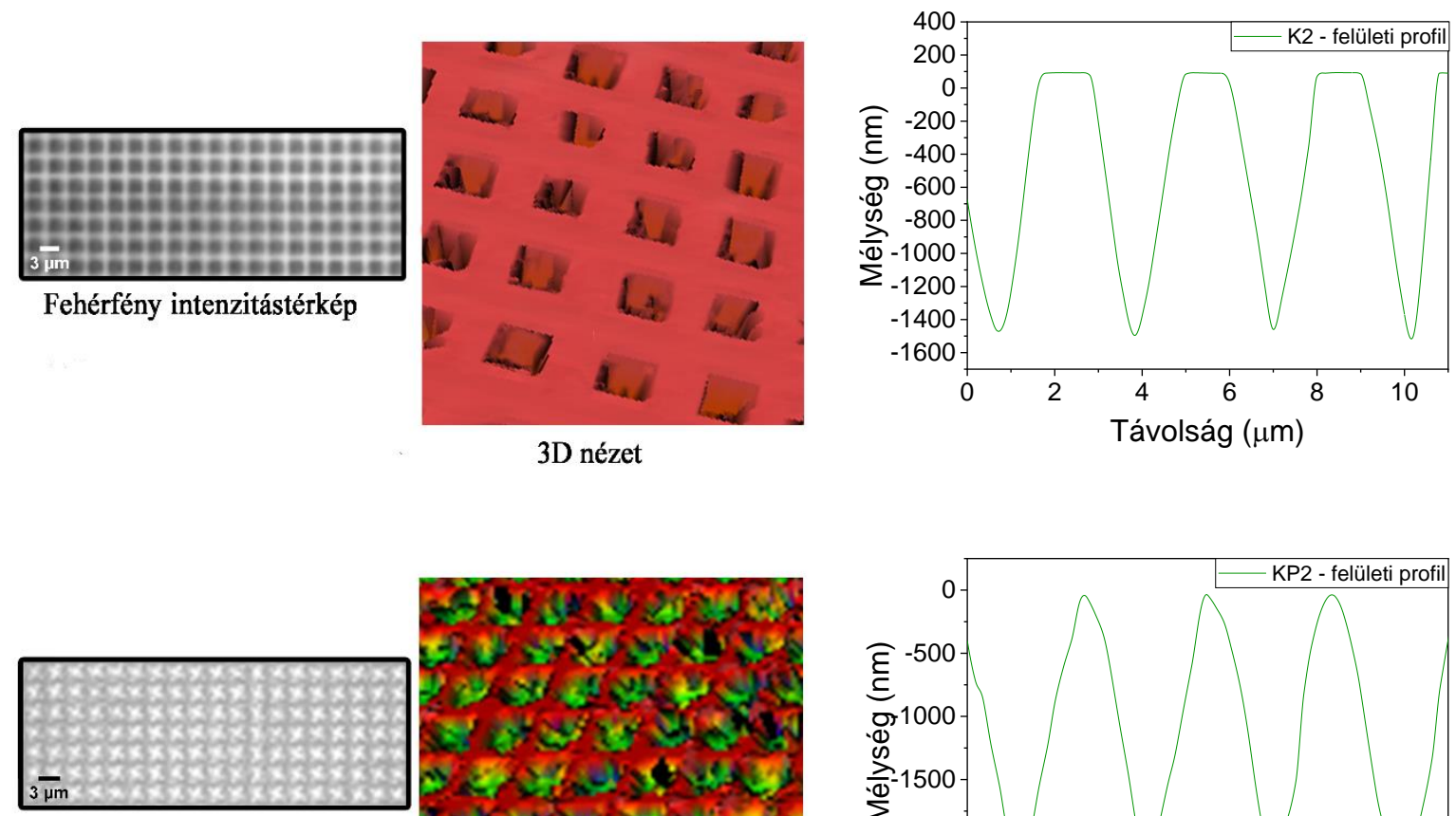

Fehérfény intenzitástérkép
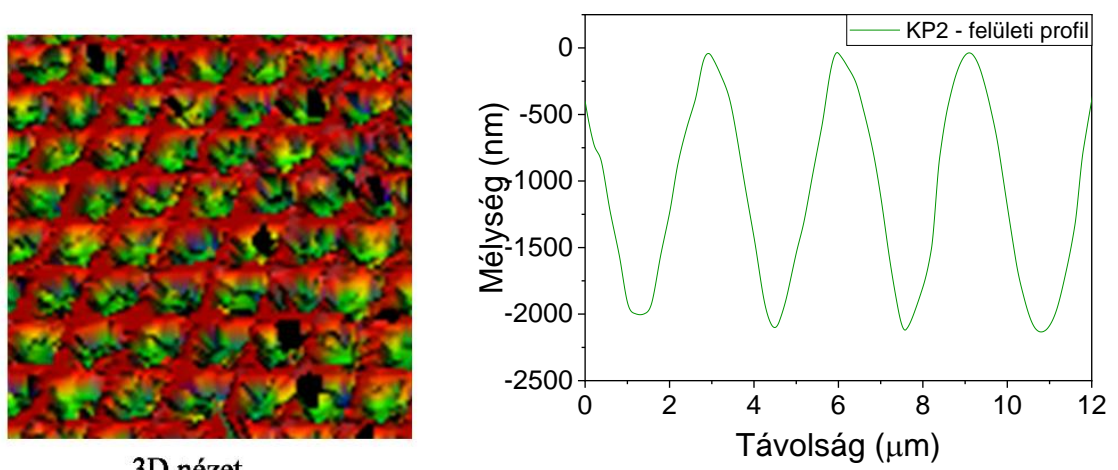

3D nézet

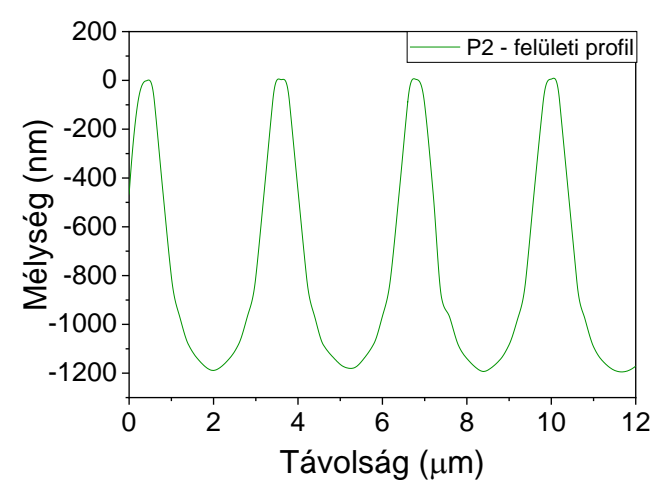

3D nézet

30. ábra: A K2, KP2 és P2 minták fehérfényü interferométerrel készitett intenzitástérképe, az interferogramokból meghatározott háromdimenziós felületi topológia, valamint a néhány szomszédos üreg középpontján áthaladó felületi profil. 
A benzofenon modellanyag K1 mintán mért normál Raman- SERS spektrumát a 31. ábra mutatja. A molekula karakterisztikus Raman-sávjai mindkét spektrumban megfigyelhetők, viszont a normál Raman spektrum (a hordozó azon részén, ahol nem lett kialakítva inverz struktúra) esetében jobb jel/zaj aránnyal és látható az is, hogy a SERSspektrumban a sávok intenzitása jóval nagyobb, mint a normál Raman-spektrumban.
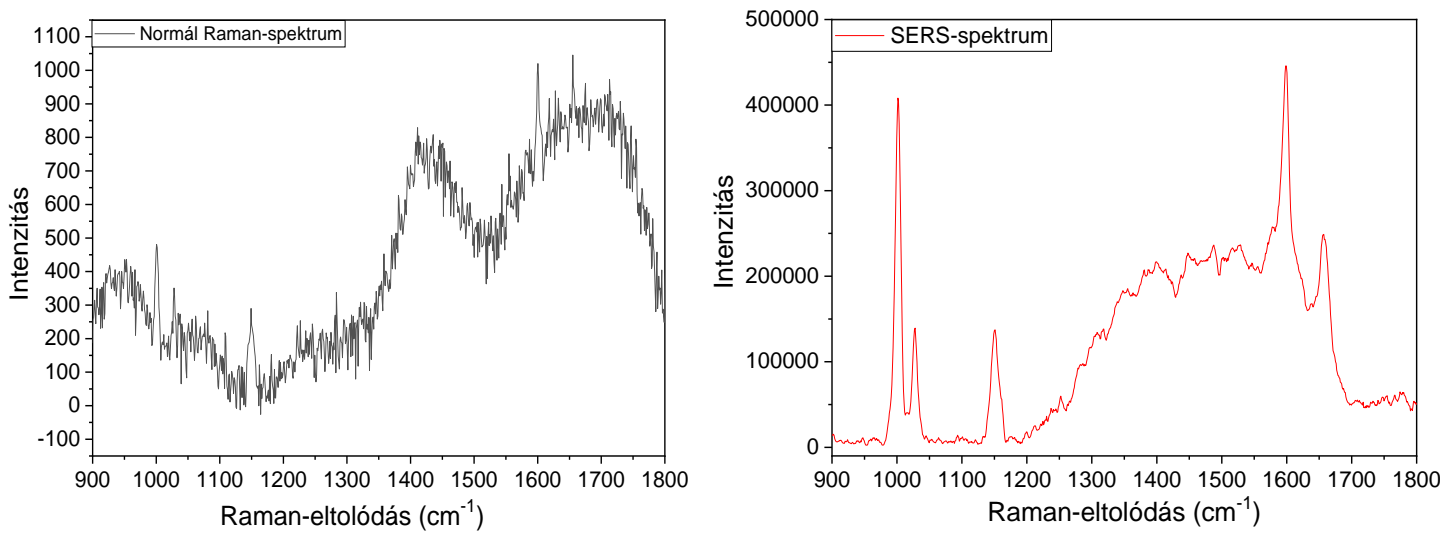

31. ábra: A K1 mintán 785 nm-es gerjesztéssel mért normál Raman-és SERS-spektrum.

A SERS-erősítési tényezőt az $1000 \mathrm{~cm}^{-1}$ körüli csúcsra határoztam meg. Az egyes mintákra kapott értékeket a 32. ábra mutatja.

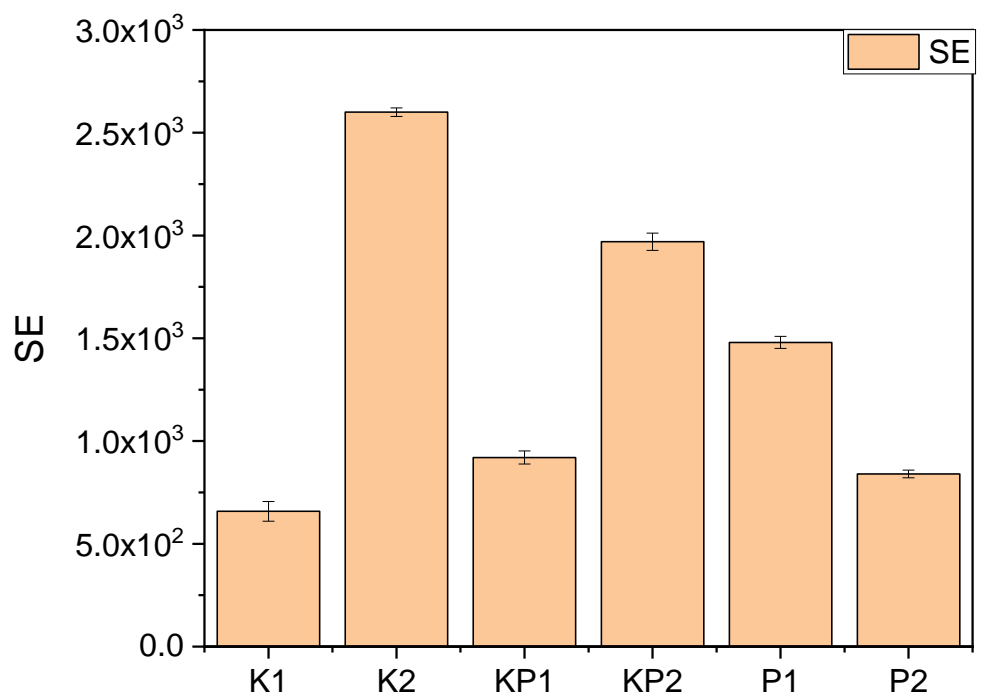

32. ábra: Az anizotrop, kevert és izotrop marással készített minták SERS-erösitési tényezöi.

Az ábrán szereplő értékek a korábban bemutatott SERS-erősítési tényezők közül a NEF normál erősítési tényezőnek felelnek meg, hiszen a normál Raman- és a SERS-spektrum rögzítése is ugyanazzal az oldattal történt. Van ugyanakkor egy tényező, ami jelentősen befolyásolja a kapott adatokat, és amit nem lehet számszerüsíteni: ez a felületi geometria hatása. 
A referenciaspektrum rögzítése arannyal bevont sík szilíciumfelületen történt, a SERS-mérés pedig arannyal bevont szilícium üregekben. A SERS-erősítés pontos meghatározásához azonos felületi borítottságot kellene elérni, az üregekben viszont biztosan nagyobb a benzofenon mennyisége, mint a síkfelületen. Bár az arany oldat általi nedvesítése a két esetben azonos, a száradási folyamat más.

Az oldatok síkfelületen szétterülő cseppjeinek párolgása kétféle mechanizmus szerint történhet [126], amit számos tényező, például a nedvesítés vagy a hőmérséklet is befolyásol. Konstans sugár esetén a csepp átmérője a felületen nem változik, hanem csak a vastagsága csökken. A beszáradás után az oldott anyag jellegzetes gyürü alakban rakódik le a felületen. Konstans nedvesítési szög esetén a csepp átmérője és vastagsága úgy csökken a párolgás során, hogy a kontaktszög nem változik. Ekkor a csepp „összezsugorodik” és a beszáradás után az oldott anyag kis területen rakódik le.

Saját kísérleteim során azt tapasztaltam, hogy a benzofenon etanolos oldata az aranyfelületen konstans nedvesítési szög mechanizmus szerint párolog, azaz az oldott anyag egy kisebb területen szárad be végül. Könnyen belátható, hogy emiatt az üregekben az anyag jóval vastagabb rétege alakul ki, mint a síkfelületen (lényegében ugyanez történik a másik párolgási mechanizmus esetén is). Bár SERS-erősítés ennek a beszáradt rétegnek csak az aranyfelület közelében található nagyon vékony rétegén történik, normál Raman-szórás révén az üregben található többi benzofenon is hozzájárul a mért SERS- (pontosabban SERS+Raman) intenzitáshoz. Emiatt az ábrán megadott $S E$ SERS-erősítési tényezők az

$$
S E=\frac{I_{S E R S}+I_{R S C}}{I_{R S S}}
$$

intenzitásarányt tükrözik, ahol $I_{S E R S}$ a SERS-intenzitás, $I_{R S C}$ az üregben, $I_{R S S}$ pedig a síkfelületen mért normál Raman-intenzitás. Az $I_{R S C}$ csökkenti a SERS-erősítés mértékét és eredményezi a bemutatott, relatíve kis értékeket. Mivel ennek értéke nem ismert és nehezen meghatározható, a továbbiakban a fenti $S E$-értéket, mint relatív felületerősítési tényezőt használtam a minták összehasonlító jellemzésére.

A 32. ábrán látható, hogy az $1 \mu \mathrm{m}$ alappal készült K1 minta rendelkezik a legkisebb SEértékkel. Ezt követi a P2, KP1 és P1 minta. A legnagyobb SERS-erősítést a KP2 és K2 mintáknál mértem. 
A $2 \times 2 \mu \mathrm{m}$ minták esetében a jól meghatározott élekkel rendelkező K2 minta a legjobb, míg az inverz ellipszoid alakú üregekkel rendelkező P2 minta a legrosszabb, a kerekített élü KP2 pedig a kettő között helyezkedik el. Ez azt mutatja, hogy a felületi görbület változása kedvez a SERS-erősítésnek. Ezt erősíti az is, hogy a K2-nél jóval nagyobb méretü, tehát nagyobb felülettel rendelkező KP2 minta SE-értéke kisebb, mint a K2-é.

Ugyanez a tendencia nem jelentkezik az $1 \mu \mathrm{m}$ mintáknál, de ott a K1-nél eleve nem volt megfelelő minőségű a marás, a P1 mérete pedig jóval nagyobb a K1-nél.

Az üregek alkotta minták SERS-erősítési mechanizmusának alaposabb megértése érdekében a SEM-képekről és fehérfényü interferometriás adatokból kapott méretekkel reprodukáltam a hordozók felületét, és azokon FDTD-szimulációval meghatároztam a térerősség eloszlását.

A 33. ábrán láthatóak az így kapott térerősség-eloszlások. Az ábrázolt monitorsíkok az üregek X- és Y-irányú szimmetriasíkjaiban (az ábrákon rendre XZ- és YZ-monitorok), valamint a hordozó felülete fölött $25 \mathrm{~nm}$ távolságban (az ábrákon XY-monitor) helyezkedtek el. Megjegyzendö, hogy mindegyik ábrához relatív intenzitásskála tartozik, amelyen a sötétvörös színhez az adott eloszlási térkép legnagyobb, a sötétkék színhez pedig a legkisebb értéke tartozik.

A 33. ábra az $1 \mu \mathrm{m}$ alappal készített minták méretei alapján felépített geometriák intenzitáseloszlását mutatja. Az anizotrop marással kapott, inverz piramis alakú szerkezet esetében az intenzitás maximuma az üreg X-irányú szimmetriasíkja mentén, azaz a beeső nyaláb polarizációjával párhuzamosan elnyújtva oszlik el.

A legnagyobb értéke az üreg középső részére koncentrálódik. Az intenzitáseloszlás az inverz ellipszoid alakú P1 minta esetében is elnyújtott a polarizációs tengely mentén, és a maximuma szintén az üreg közepére lokalizálódik. 


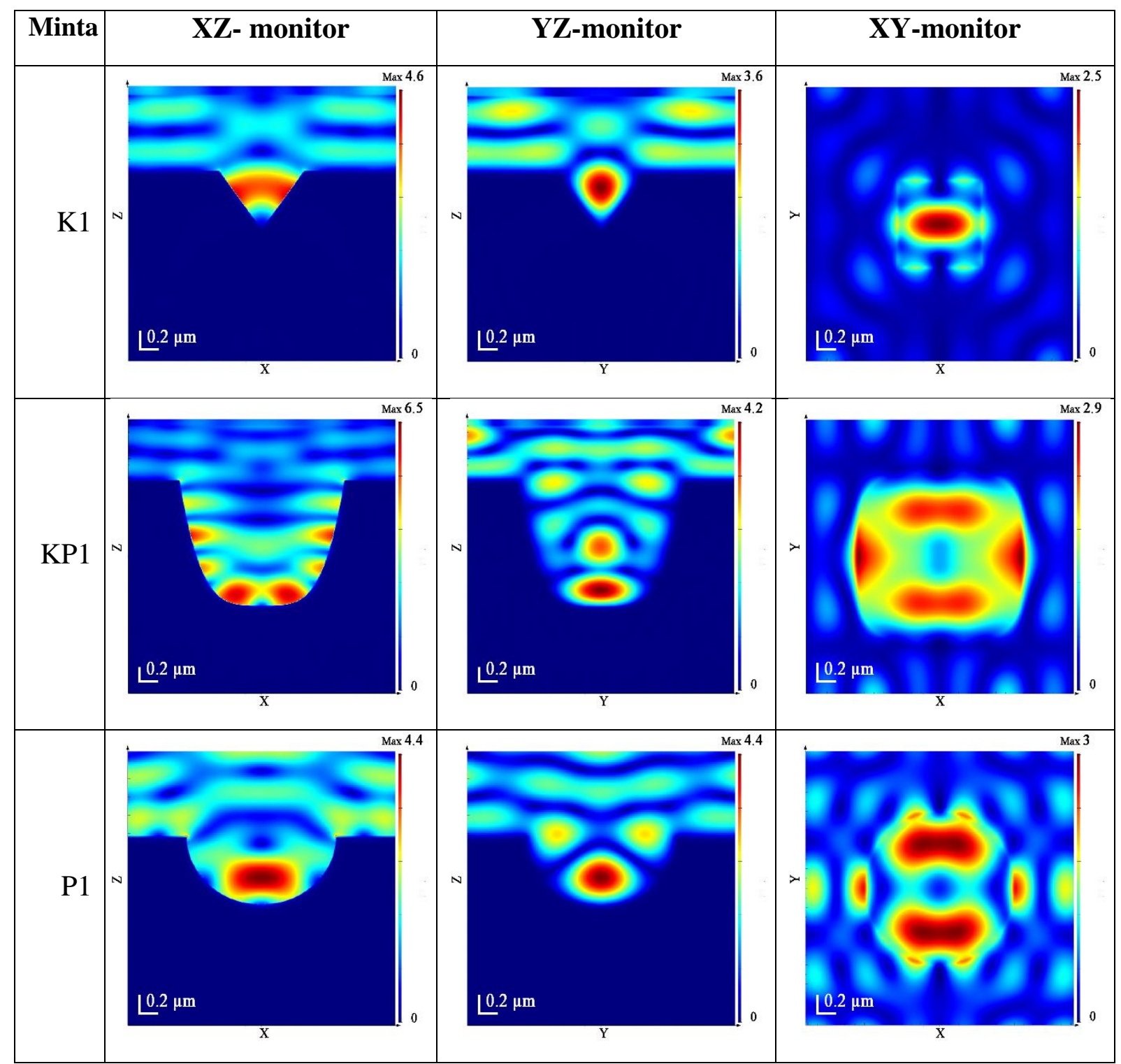

33. ábra: Az elektromágneses tér intenzitáseloszlása a K1, KPl és P1 minták méretei alapján készült modellgeometriák polikromatikus elektromágneses síkhullámmal való kölcsönhatása során.

A KP1 minta jóval összetettebb intenzitáseloszlási képet mutat. A legmagasabb intenzitás az üreg alsó részén összpontosul, de hotspotok figyelhetők meg az oldalakon is, melyek közül az X-irányban átellenesek az intenzívebbek.

A $2 \times 2 \mu \mathrm{m}$ mintákon kapott intenzitáseloszlásokat a 34. ábra mutatja. Az intenzitás-eloszlási képek - többek között a nagyobb geometriai méretek miatt - jóval összetettebbek. 


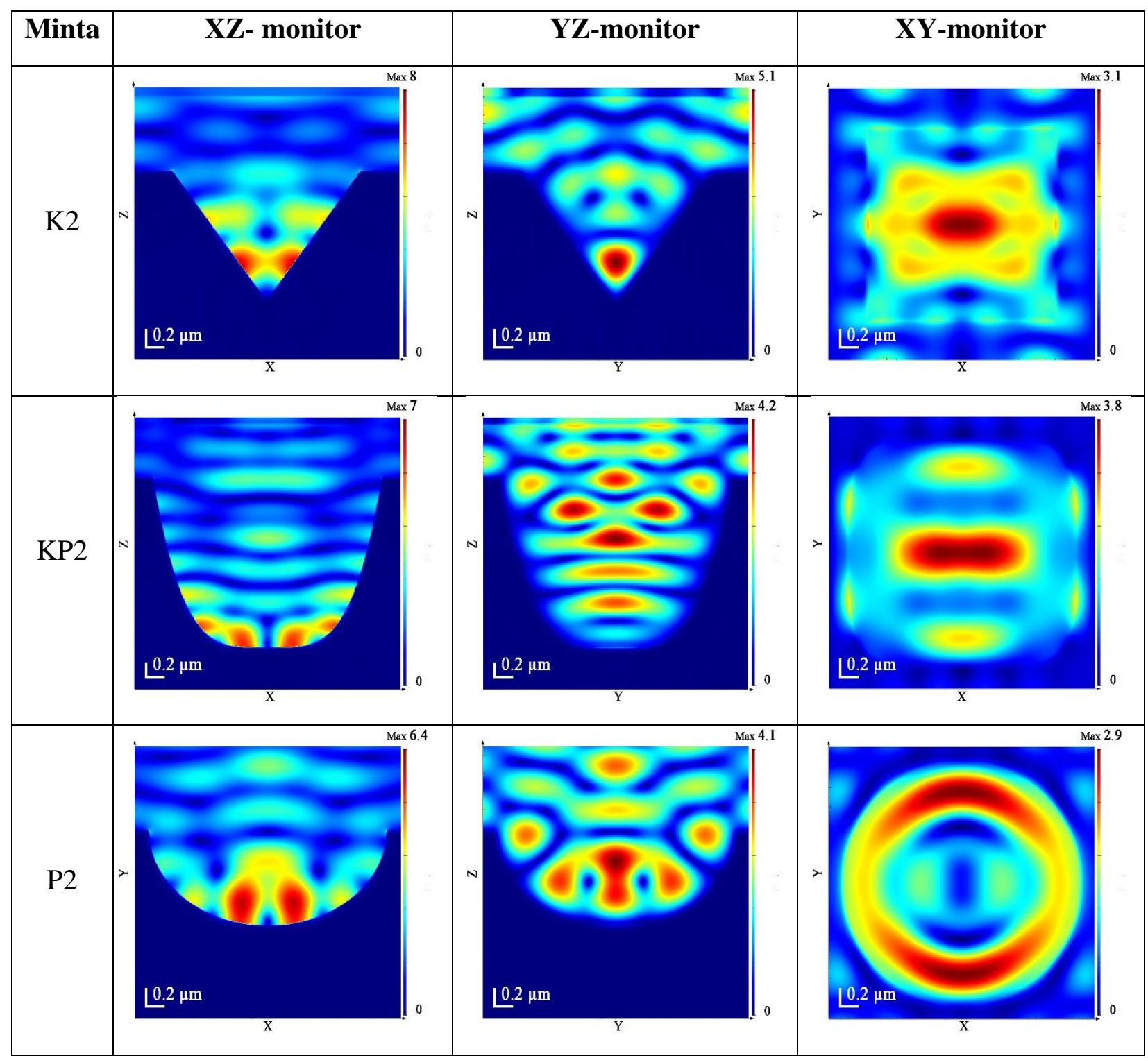

34. ábra: Az elektromágneses tér intenzitáseloszlása a K2, KP2 és P2 minták méretei alapján készült modellgeometriák polikromatikus elektromágneses síkhullámmal való kölcsönhatása során.

A K2 mintánál a maximum itt is a polarizációval párhuzamos irányban nyúlik el, és maximuma az üreg alsó részére összpontosul. Az üreg mélység szerinti felső kétharmadában jóval kisebb intenzitások figyelhetők meg. Különösen érdekesek a P2 minta eredményei, ahol az XY-monitornál gyürü alakú eloszlás figyelhető meg. Emellett itt is az üreg alsó részében figyelhetők meg maximumok. A KP2 mintánál a hotspotok eloszlása összetett, igazán nagy értékek az XY-monitor síkjában, az üreg középső részén figyelhetők meg. 
A különböző modelleken kapott maximális számított erősítési tényezőket a 35. ábra mutatja. Látható, hogy a legnagyobb érték a K2 mintához tartozik, ezt követi a KP2, majd a KP1 minta. Legkisebb értékekkel a K1 és P1 minták rendelkeznek.

A K2 és KP2 mintákra kapott legmagasabb értékek jó összhangban vannak a kísérletileg mért adatokkal (lásd: 32. és 35. ábra), akárcsak a K1 mintára kapott minimális értékek. Hasonló módon, a $2 \mu \mathrm{m}$ mintáknál is teljesül a K2 > KP2 > P2 összefüggés, míg az $1 \times 1 \mu \mathrm{m}$ mintákra nem.

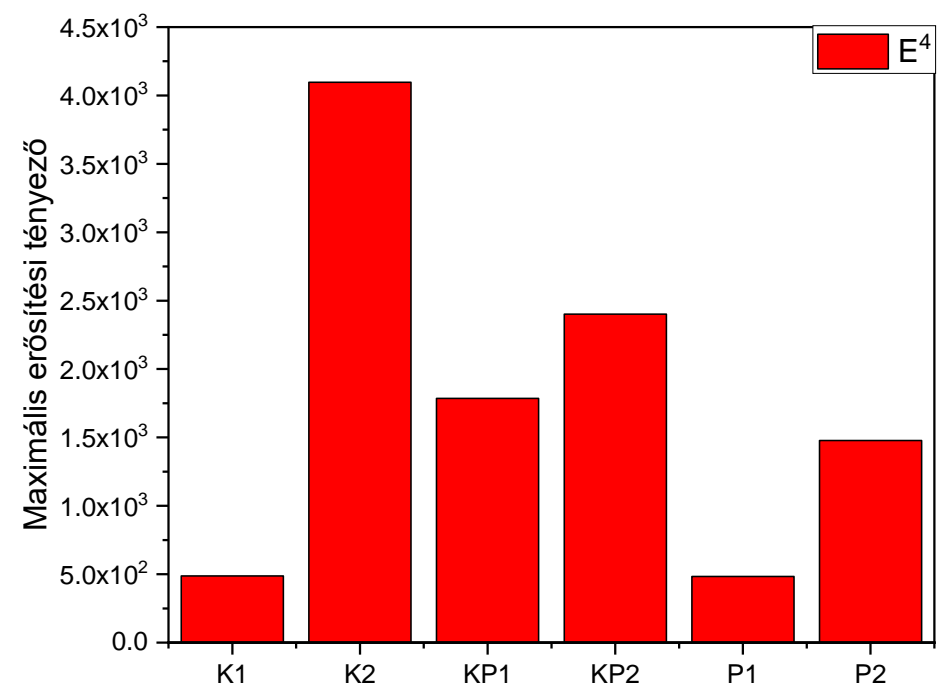

35. ábra: Az FDTD- szimulációkból az egyes modellekre kapott maximális erösítési faktorok.

A modellezéssel kapott és a mért eredmények összevetése szempontjából nem mindegy, hogy kisebb térerősség oszlik meg egy nagyobb, vagy nagyobb térerősség koncentrálódik egy kisebb térfogatban, mivel a normál Raman- és a SERS-intenzitás szempontjából is fontos a gerjesztett molekulák száma. Ugyanakkor, bár az inverz üregekben kiülepedett anyag mennyiségét nem vizsgáltam direkt módon, a mérésekhez használt oldat koncentrációja kicsi volt, és a mérések során az optikai mikroszkóp alatt nem tapasztaltam az üregek feltöltődését. Ennek figyelembevételével viszont elmondható, hogy csak az üregek alját és oldalfalának egy részét borította a mérendő anyag. A modellezés alapján ide lokalizálódnak a legintenzívebb hotspotok is, ami erősíti a térerősség maximumának és a SERS-erősítésnek a korrelációját. Emellett a szakirodalomban is elfogadott a SERS-erősítésért felelős hotspotokat a maximális térerősség alapján meghatározni, és az elektromos térerősség alapján számított |E4| erősítési tényezővel összevetni a kísérletileg mért SERS-erősítést [127 - 129].

A téreloszlás elemzése és az erősítési faktor számítása mellett a szimuláció lehetővé tette a reflexiós spektrum meghatározását is. A SERS-hordozók plazmonikus jellemzői reflexiós 
spektrumokra gyakorolt hatásának tanulmányozásához sík aranyfelület reflexióját is modelleztem, majd azt használtam referenciaként a SERS-hordozók reflexiójának meghatározásához. A 36. és 37. ábrák az $1 \times 1$ és $2 \times 2 \mu \mathrm{m}$ mintákra kapott adatokat mutatják. Az ábrákat nézve a legszembetűnőbb dolog a reflexiós görbék fluktuálása a hullámhosszal. A sík aranyfelület reflexiós görbéje ebben a hullámhossz-tartományban lassan, de folytonosan csökkenve változik (lásd a betétet a 36. ábrán), és abban semmilyen fluktuáció nem figyelhető meg. A reflexió változásainak oka a struktúrák plazmonjellemzőivel hozható összefüggésbe.

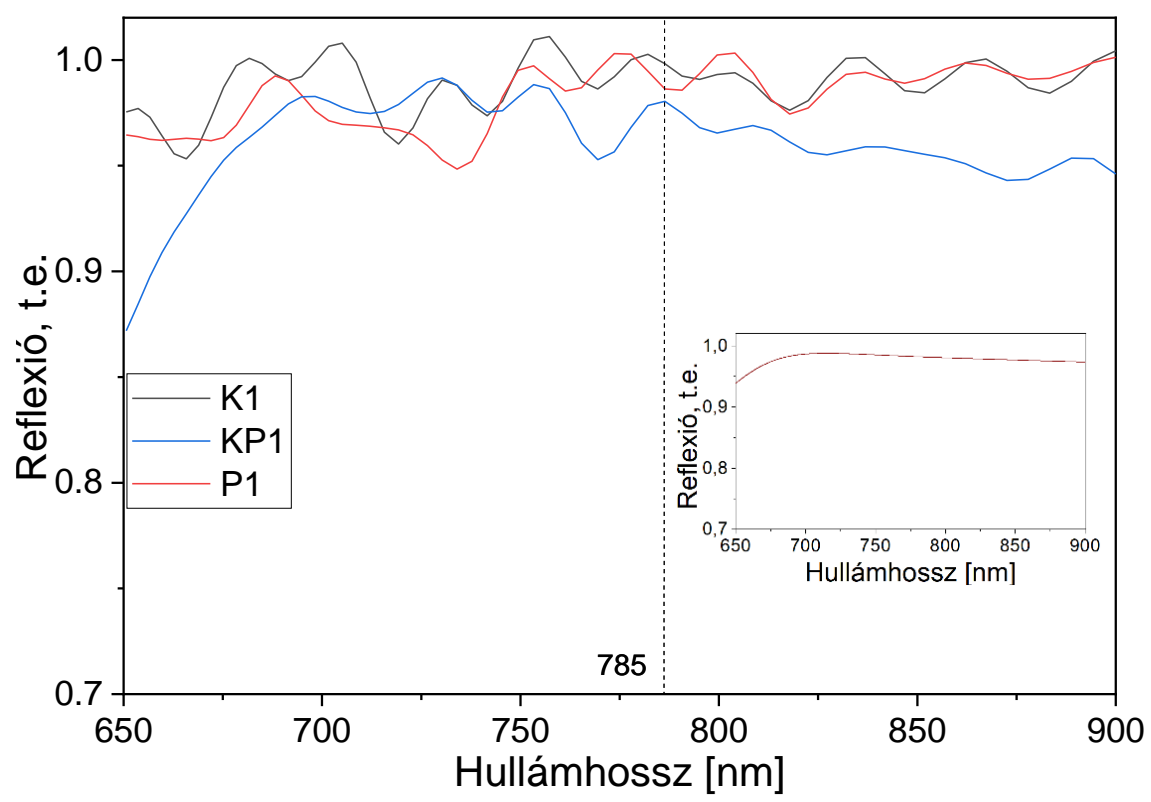

36. ábra: A K1, KPl és Pl minták modellezett reflexiós spektruma. A betét a sík aranyfelület reflexióját mutatja.

A reflexiós görbék összehasonlítása azt mutatja, hogy egyrészt a felületek több kisebb plazmonrezonancia-hullámhosszal rendelkeznek (plazmonrezonancia esetén megnő az abszorpció, a reflexió értelemszerüen csökken).

Látható az is, hogy az $1 \times 1 \mu \mathrm{m}$ mintáknál a reflexió változása kisebb mértékü, mint a $2 \times 2 \mu \mathrm{m}$ mintákban. A hat minta közül a legnagyobb reflexiócsökkenést a KP2 minta mutatja, ezt követi a K2. Bár a sorrend más (a KP2 jobb, mint a K2, mivel összességében ennek az üregnek a legnagyobb a térfogata), ez jól összecseng a mért és számított SERS-erősítésekkel. A reflexiós minimumok 15-20 nm-es tartományokra terjednek ki, ami azt jelzi, hogy a felületek SERS-erősítése erősen hullámszámfüggő lesz. 


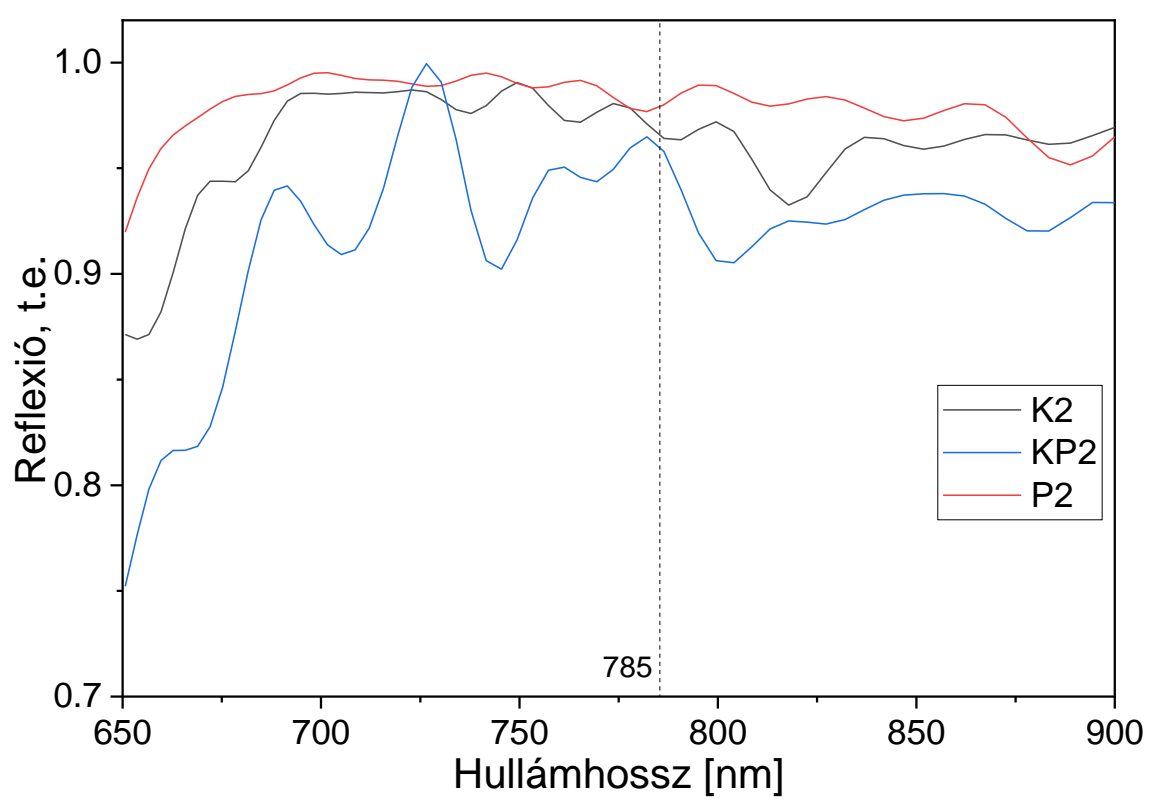

37. ábra: A K2, KP2 és P2 minták modellezett reflexiós spektruma.

Emellett a különböző minták reflexiós minimumai nem azonos hullámhosszaknál jelentkeznek, így könnyen előfordulhat, hogy bizonyos hullámszámtartományba eső Ramancsúcsokat egy általánosan rosszabb plazmonikus jellemzőkkel bíró minta fog jobban erősíteni.

Összességében elmondható, hogy a fotolitográfiával, izotrop és anizotrop marással, valamint ezek kombinálásával szilíciumban előállított periodikus inverz struktúrák közül az éles élekkel rendelkező $2 \times 2 \mu \mathrm{m}$ szerkezet mutatta a legjobb SERS-erősítést, amitől nem maradt el jelentősen a lekerített élű üregekkel rendelkező minta. Az FDTD-modellezéssel kapott téreloszlások elemzése alapján elmondható, hogy a SERS szempontjából legjobban teljesítő mintákban a térerősség maximuma az üreg alsó részére koncentrálódott. A modellezés azt is megmutatta, hogy a hordozók SERS-erősítése hullámszámfüggő.

\subsection{Mikroszkopikus objektumok csapdázására és SERS-vizsgálatára alkalmas perforált hordozók előállítása és jellemzése}

Az előző fejezetben vizsgált minták csak korlátozottan alkalmasak mikroobjektumok csapdázására és SERS-vizsgálatára. Különösen az előbbi müködik alacsony hatékonysággal, mivel az alulról zárt üregekbe kis hatékonysággal juttathatók be a vizsgálni kívánt objektumok, azok rögzítése pedig még nehezebb feladat. Erre megoldást jelenthet egy átfolyásos SERShordozó, melynél a méretek jó megválasztásával elérhető, hogy a csapdázni kívánt objektumok bejussanak az üregekbe, kijutni viszont már ne tudjanak onnan. A hordozó két oldalán 
alkalmazott nyomáskülönbséggel a minta például egy mikrofluidikai rendszerrel „átszívható” a hordozón, de annak a perforáció méreténél nagyobb komponensei fennakadnak az üregekben, és azokon elvégezhető a SERS-mérés. Munkám során két ilyen hordozót is terveztem és jellemeztem, amelyeket polimer mikrogömbök és vörösvértestek csapdázására és SERSspektrumainak rögzítésére használtam. Az alábbiakban az ezekkel kapcsolatos eredményeket mutatom be.

\subsubsection{SERS-hordozó mikrogömbök csapdázására és jellemzésére}

Az általunk megtervezett átfolyásos SERS-hordozó sematikus képét a 38. ábra mutatja. Az elóállítási módszer ebben az esetben is litográfia, a hordozó viszont nem szilíciumlapka, hanem egy szilícium-szigetelő (SOI) szendvicsszerkezet. Az üregek kialakítása az előző fejezetben is használt anizotrop marási eljárással történik, itt is precízen kell kontrollálni a marás időtartamát. Amikor a reakció a felületről átér a szigetelőig, az üreg mélysége már nem tud tovább növekedni. Oldalirányban viszont folytatódik a marás (nemcsak az üreg alján, de annak teljes vastagságában), és a szigetelő egyre nagyobb felületéről tünik el a szilícium. A kémiai reakció időtartamával befolyásolható, hogy a szigetelő felületének mekkora területe váljon szabaddá. A következő lépésben, egy másik marószer alkalmazásával szelektíven eltávolítható a szigetelőréteg, és megmarad a vékony, perforált szilíciumréteg vagy szilíciummembrán. Az előállítás utolsó lépése a SERS-aktivitáshoz szükséges aranyréteg leválasztása az így kapott struktúrára.

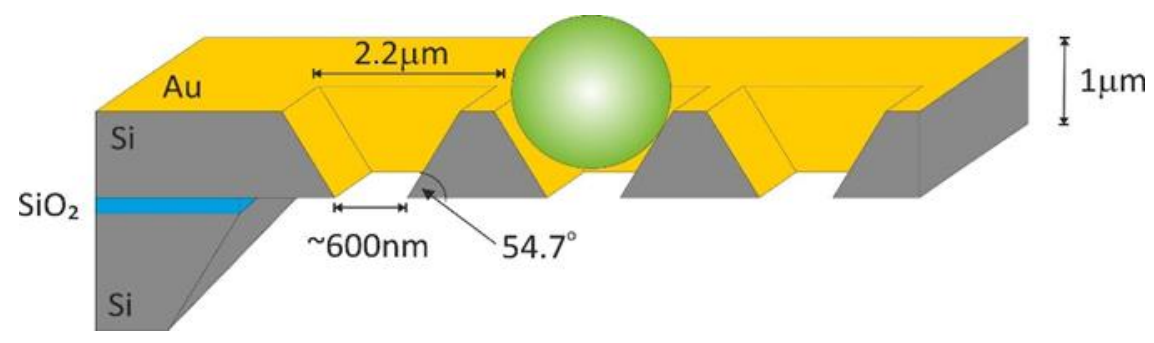

38. ábra: Az átfolyásos SERS-hordozó vázlatos geometriája egy csapdázott mikrogömbbel.

Egy ilyen perforált hordozó csapdázási képességeit a geometriai méretek határozzák meg. Az anizotrop marás jellegzetessége, hogy az üreg oldala $54,7^{\circ}$-os szöget zár be a lapka felületével. Ezen változtatni nehezen lehet, mint ahogy a SOI-struktúra szilíciumrétegének 1 $\mu \mathrm{m}$ vastagságán sem. A kettő együttesen meghatározza, milyen lesz a nyílások méretének aránya a SOI felszínén és az alján. Ezt a (43) képlet adja meg:

$$
A_{B}=A_{S}-2 \cdot d \cdot \operatorname{tg}\left(90^{\circ}-\alpha\right)
$$


ahol $A_{S}$ és $A_{B}$ a nyílás mérete a felület tetején és alján, $d$ a SOI-réteg vastagsága, $\alpha$ pedig a felület és az üreg oldala által bezárt szög $\left(54,7^{\circ}\right)$. $1 \mu \mathrm{m}$ vastagság esetén, maszkként egy $2 \times 2$ $\mu \mathrm{m}$ alapéllel rendelkező négyzetet használva az alsó, négyzet alakú nyílás alapjának méretére $0,6 \mu \mathrm{m}$ (38. ábra:).

A 39. ábra a fenti méretekkel készült és arannyal már bevont SERS-hordozó SEM-képeit mutatja. Jól megfigyelhető a periodikus, rendezett struktúra. Az alámarás miatt a felületen a négyzet alakú nyílás 2,2 × 2,2 $\mu$ m (ami a 150 nm-es aranybevonat nélkül 2,5 × 2,5 $\mu \mathrm{m}$ méretű szilíciumszerkezetnek felel meg). A felületen, a sarkokban az aranyréteg miatt lekerekítések figyelhetők meg. Az anizotrop marásnak köszönhetően az üregek sík oldalfelületeit éles élek határolják. Az alsó nyílás mérete $0,5 \times 0,5 \mu \mathrm{m}$, kisebb, mint a számítás alapján elvárt $0,8 \times 0,8 \mu \mathrm{m}$, aminek oka feltételezhetően az aranyréteg nagyobb vastagsága az üreg alján. A cellatávolság (a felület periodicitása) 3 mikrométer.
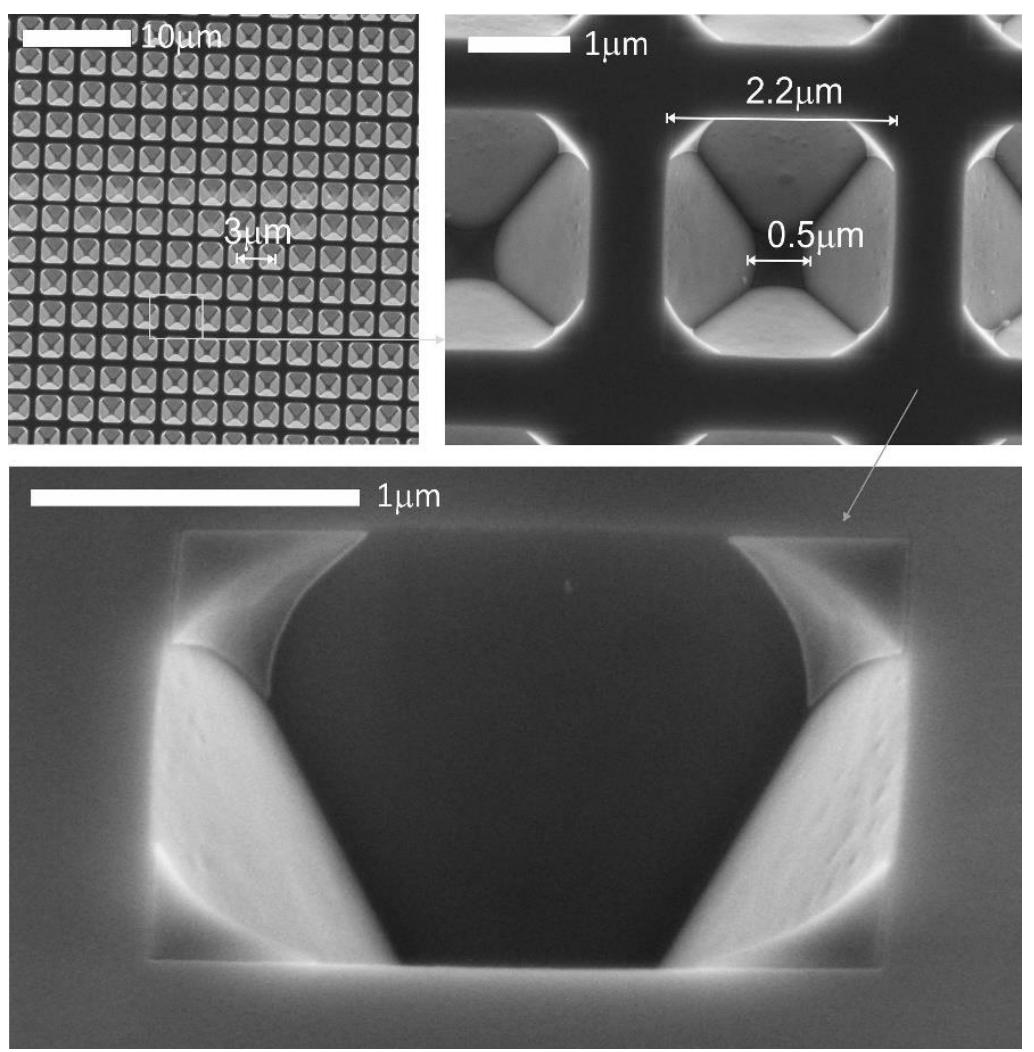

39. ábra: A periodikus perforált SERS-hordozóról készült különböző nagyitású SEM-képek az üregek méreteivel.

Az így előállított minta méretadatait felhasználva ennél a struktúránál is modelleztem az elektromos téreloszlást a polikromatikus síkhullámmal való kölcsönhatás során, valamint az elméleti erősítési faktort. A geometriai méreteket leszámítva a számolási paraméterek azonosak voltak az előző fejezetben bemutatott modelleknél használtakkal. A 40. ábra a térerősség 
eloszlását mutatja az XZ-, YZ- és XY monitorok síkjában. Megjegyzendő, hogy mindegyik ábrához relatív intenzitásskála tartozik, amelyen a sötétvörös színhez az adott eloszlási térkép legnagyobb, a sötétkék színhez pedig a legkisebb értéke tartozik. Az ábrán látható, hogy az üres SERS-hordozónál a hotspotok az üreg belsejébe koncentrálódnak. A beeső fény polarizációjával párhuzamos XZ-monitorsíkban általában alig figyelhető meg intenzitás, a kilépő nyílásnál levő éleken viszont jelentős térerősség lokalizálódik. Az YZ-síkban három hotspot is megfigyelhető: egy az üreg közepén, és további kettő a felső részén, az oldalfalakhoz közel. Az XY-monitorsíkban a legnagyobb intenzitást mutató részek az X-irányú két átellenes oldalfalnál figyelhetők meg. Az üres perforált hordozónál a legnagyobb térerősségérték 11,0 (az XZ-síkban az alsó nyílás élein koncentrálódva), ami másfélszer nagyobb, mint a zárt üregekre az előző fejezetben kapott legjobb érték.

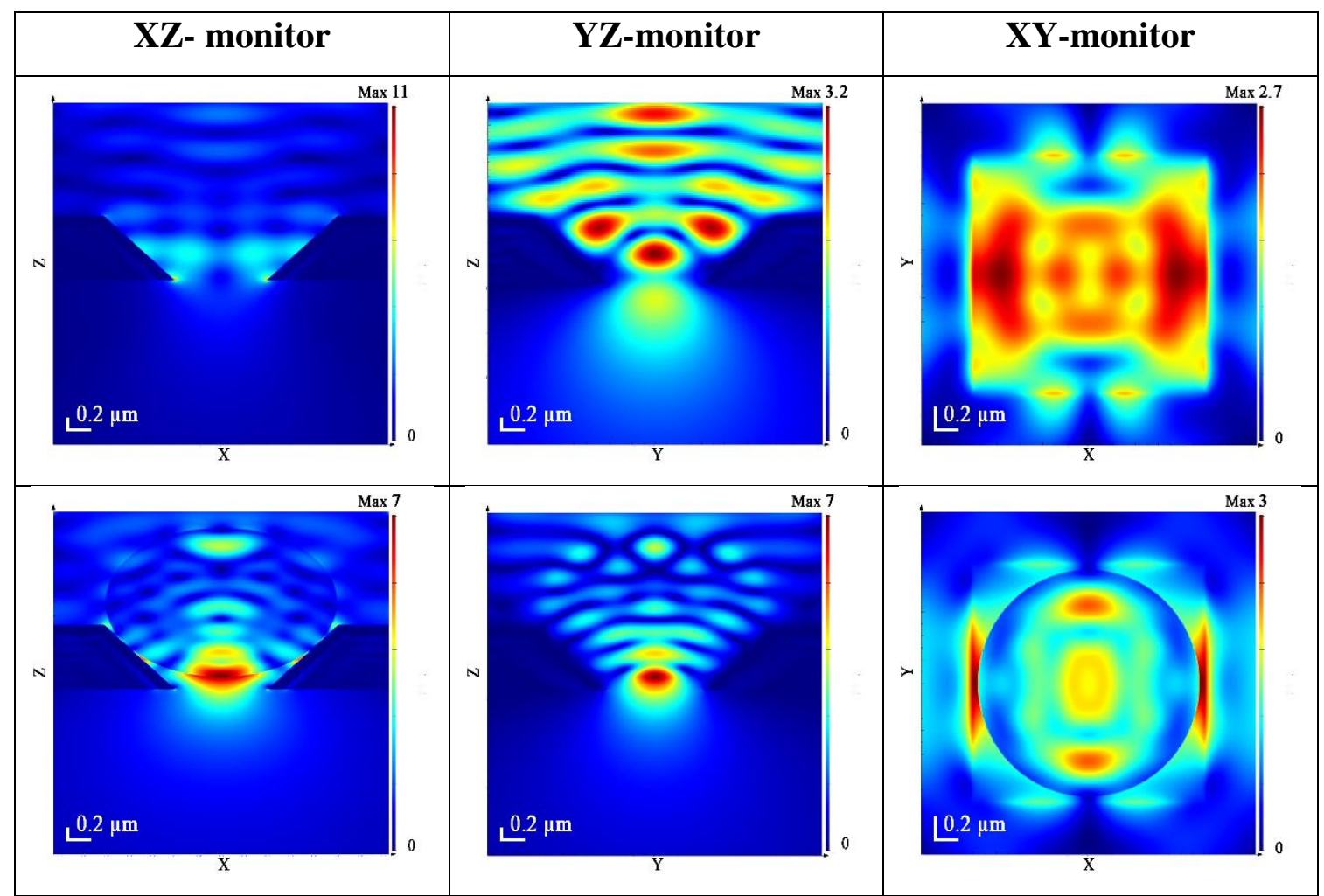

40. ábra: Üres (felső sor) és 2 um átmérőjü csapdázott polisztirol gömböt tartalmazó (alsó sor) aranybevonatos perforált SERS-hordozó téreloszlása az XZ-, YZ-és XYmonitorsikokban.

A téreloszlás jelentős átrendezése figyelhető meg, amikor az üregbe egy $2 \mu \mathrm{m}$ átmérőjű mikrogömb kerül (40. ábra, alsó sor). A hotspotok az XZ- és az YZ-síkokban egyaránt közvetlenül a mikrogömb felületére, a perforált hordozó alsó nyílásának közepére koncentrálódnak. Megfigyelhető az is, hogy a maximális értékkel rendelkező tartomány a mikrogömb belsejébe került. További hotspotok figyelhetők meg az XY-síkban, ahol ezek a 
polarizációs irány a meröleges oldalfalakon, a mikrogömb és a SERS-felület érintkezési pontjának környékén lokalizálódnak. A térintenzitás maximális értéke 7,0 és a perforált szerkezet alsó nyílásánál található.

A kísérleti adatok bemutatása előtt érdemes megemlíteni, hogy a modellezés alapján a mikrogömböt tartalmazó perforált hordozó kifejezetten ígéretesnek tủnik az utóbbi időben intenzíven kutatott fotonikus nanosugarak („photonic nanojets”) előállítására [130]. A fotonikus nanosugarak előállítására képes, szigetelő anyagokból készült struktúrák az első, a gyakorlatban is müködő nem fémes plazmonikus szerkezetek közé tartoznak.

A hordozó csapdázási képességét $2 \mu \mathrm{m}$-es polimer mikrogömbökkel teszteltük. Ehhez kétféle, fotolumineszcens tulajdonságokkal rendelkező polimer mikrogömböt használtunk. A szuszpenziót a minta felületére cseppentettük, és megvártuk, amíg a folyadék átfolyik az üregeken, majd desztillált vízzel leöblítettük. A 41. ábra a felület fluoreszcencia-mikroszkópos felvételét mutatja. A fluoreszcens emissziónak köszönhetően jól megfigyelhetők a felületen rögzült mikrogömbök. Az SA és ST minták eltérő (zöld és kék) emissziós hullámhossznak köszönhetően a kétféle mikrogömb jól megkülönböztethető.

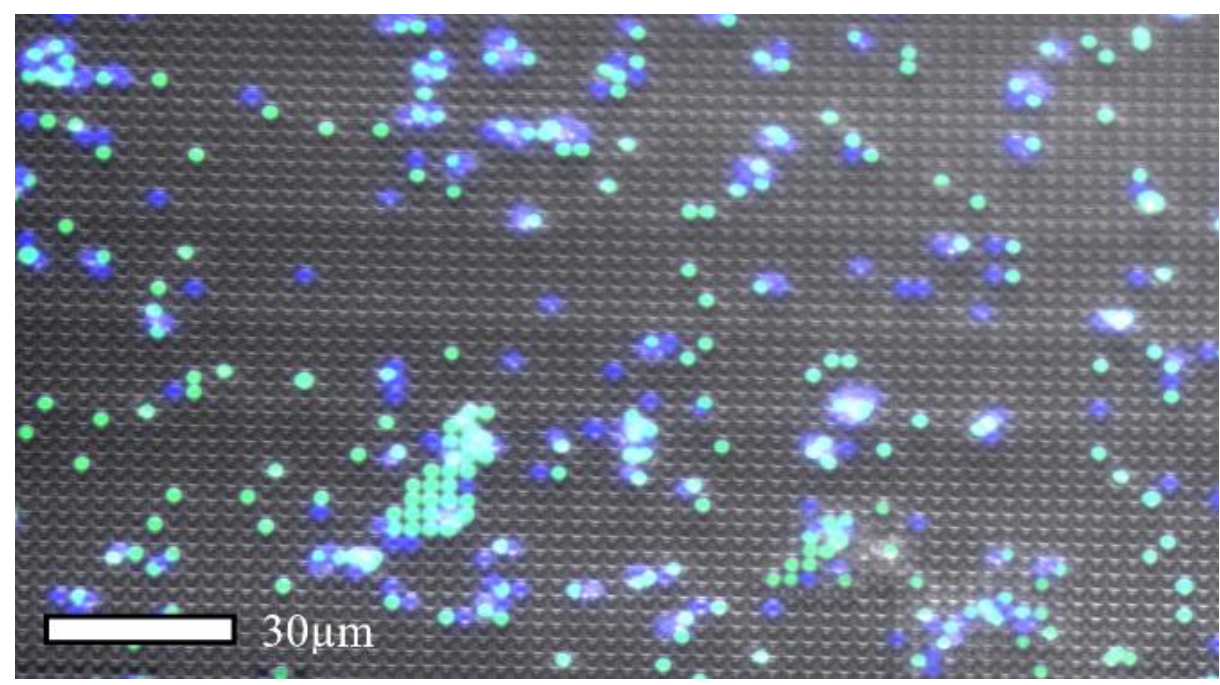

41. ábra: A perforált SERS-hordozón csapdázott 2 um körüli átméröjü SA (zöld) és ST (kék) fluoreszcens mikrogömbökfluoreszcencia-mikroszkópos képe.

Egy csapdázott mikrogömb SEM-képét a 42. ábra mutatja. Mivel az üreg felső nyílásának mérete $2,2 \mu \mathrm{m}$, a $2 \mu \mathrm{m}$ átmérőjü mikroobjektum mélyen ül az inverz piramisban. Annak felületével a négy oldal szimmetriasíkjaiban, a mélységet tekintve valahol az üreg alsó harmadában érintkezik. 


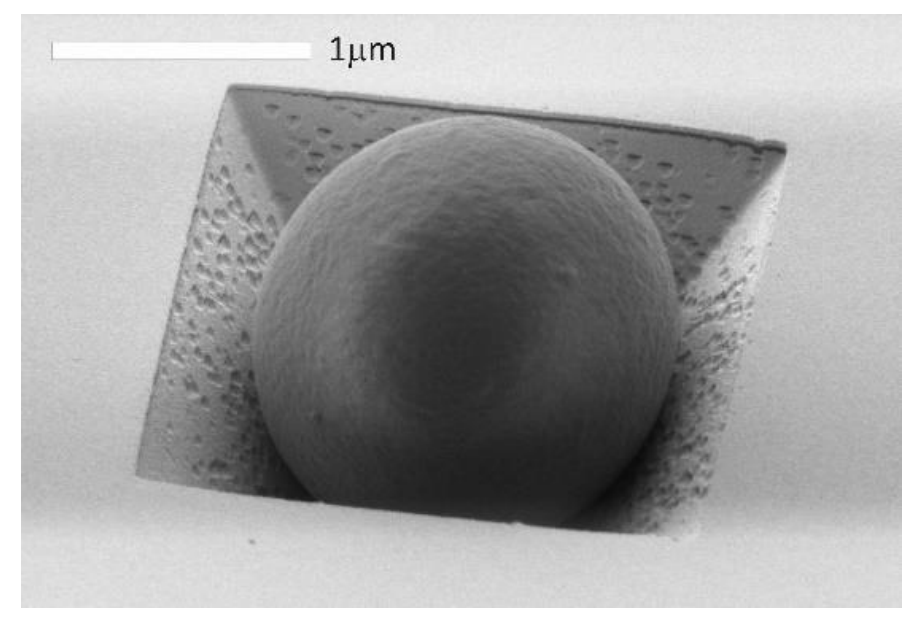

42. ábra: A 2 4 m átméröjü SA mikrogömb SEM képe.

Az üres szerkezet modellezett reflexiós spektrumát a 43. ábra mutatja. A reflexió 500 és $750 \mathrm{~nm}$ között összességében nő a hullámhosszal, de több lokális minimuma is megfigyelhetö. A visszaverődés élesen csökken a 630 és $650 \mathrm{~nm}$ közötti tartományban, itt a minimum 642 nm-nél található. Egy másik, szélesebb tartomány található 660 és 750 nm között, ahol a lokális minimumok 675 és 690 nm-nél figyelhetők meg.

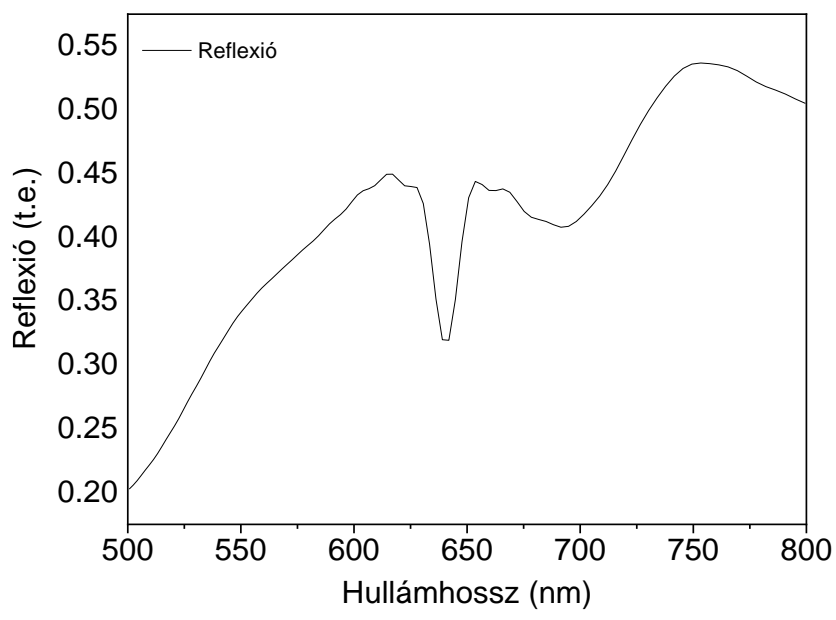

43. ábra: A perforált inverz piramisok FDTD szimulációval meghatározott reflexiós spektruma.

A hordozó SERS-erősítését a csapdázott polimerekkel teszteltem. A 44. ábra az SA minta mért normál Raman-, valamint a perforált hordozón mért SERS-spektrumát hasonlítja össze. A normál és felületerősített Raman-spektrumok között - utóbbi javára - jelentős intenzitásnövekedés figyelhető meg. A benzofenon jellegzetes sávjai mindkét spektrumban megjelennek. A $1603 \mathrm{~cm}^{-1}$ sávra számított SE-érték 40 körüli. Várható volt, hogy az érték nem lesz túl magas, mivel a SERS-spektrumban is benne van a teljes mikrogömb normál Raman- 
járuléka, felületerősítés viszont csak a mikroobjektumnak az üreggel közvetlenül érintkező felszíni régióiból származik. A Raman-erősítés jól mutatja a minta SERS-aktivitását.

Az üres hordozón mért referenciaspektrumban nem láthatók keskeny Raman-csúcsok. Csak kis intenzitású, széles sávok figyelhetőek meg 1400-2000 cm-1 között, amelyek feltételezhetően valamilyen, a felületen adszorbeálódott szennyeződés fluoreszcenciájához rendelhetők. A polimer mikrogömb normál Raman-spektrumában egyetlen sáv azonosítható be $1600 \mathrm{~cm}^{-1}$ körül. A SERS-spektrumban már jóval több sáv figyelhető meg.

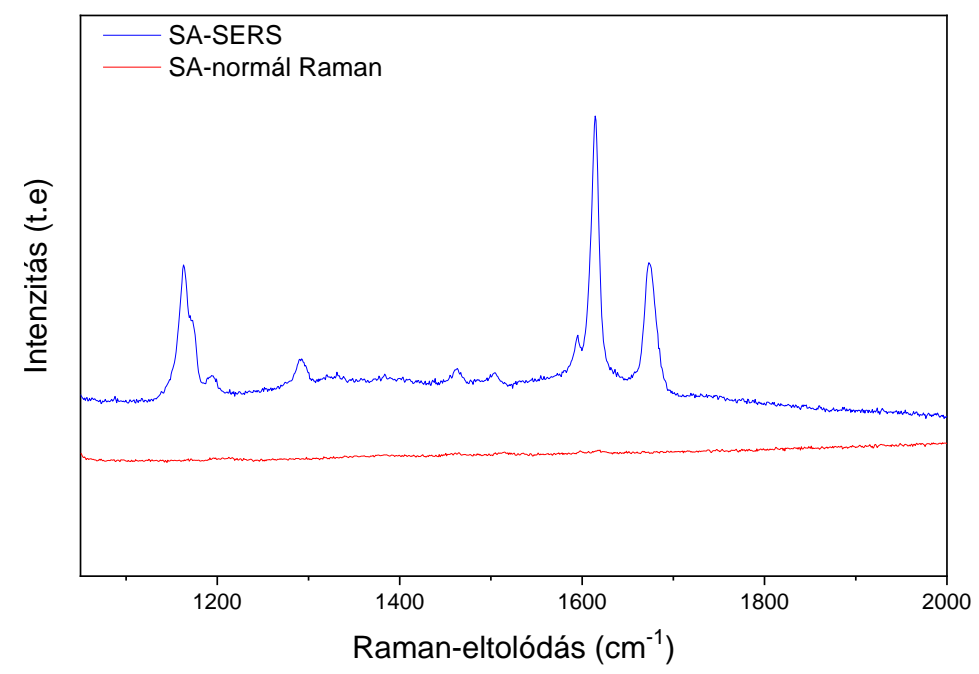

44. ábra: Az SA mintán mért normál Raman- és SERS-spektrumok, valamint az üres hordozón mért referenciaspektrum.

Az ST mintán mért spektrumokat a 45. ábra mutatja.

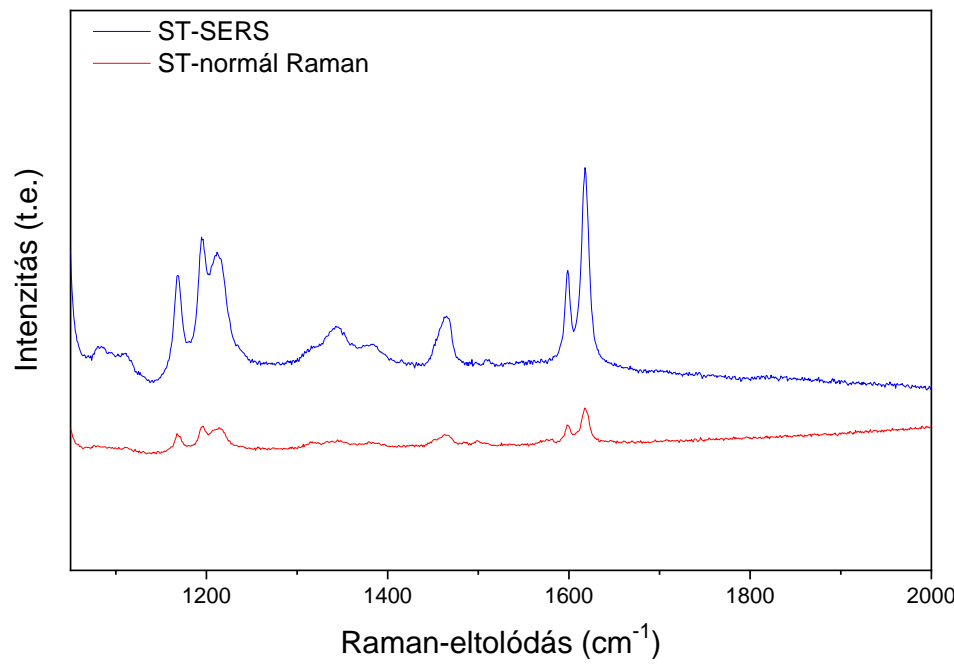

45. ábra: Az ST mintán mért normál Raman- és SERS-spektrumok, valamint az üres hordozón mért referenciaspektrum. 
A normál Raman-spektrum informatív, abban számos sáv figyelhető meg. A SERSspektrum itt is jóval intenzívebb, a sávok túlnyomó többsége jó egyezést mutat a normál Raman-spektrummal. Az erősítési tényező 28 körüli.

Az SA és ST minták normál és felületerősített Raman-spektrumában megfigyelhető Raman-sávok pozícióit a 4. táblázat foglalja össze. Bár az SA minta normál Ramanspektrumában egyetlen sávot sikerült azonosítani, az ST mintában már számos csúcsot sikerült azonosítani. Ezek mindegyike jó egyezést mutatott a polisztirol Raman-sávjaival [131, 132]. Ezek a sávok a SERS-spektrumokban is megjelennek.

4. táblázat: Az SA és ST polimer mikrogömb minták normál Raman-és SERS-spektrumaiban megfigyelhetö Raman-sávok pozíciói.

\begin{tabular}{|c|c|c|c|c|}
\hline \multicolumn{5}{|c|}{ Raman-csúcs pozíció, cm-1 $^{-1}$} \\
\hline \multicolumn{2}{|c|}{ SA minta } & \multicolumn{2}{|c|}{ ST minta } & \multirow{3}{*}{$\begin{array}{c}\text { Polisztirol } \\
\text { Normál } \\
\text { Raman }\end{array}$} \\
\hline SERS- & Normál & SERS- & Normál & \\
\hline & Raman & & Raman & \\
\hline & & 1110 & & \\
\hline 1163 & & 1168 & 1168 & 1156 \\
\hline \multirow[t]{2}{*}{1194} & & 1194 & 1195 & 1196 \\
\hline & & 1212 & 1212 & \\
\hline \multicolumn{5}{|l|}{1292} \\
\hline \multirow[t]{2}{*}{1333} & & 1343 & 1343 & 1326 \\
\hline & & 1383 & 1383 & \\
\hline 1463 & & 1465 & 1465 & 1448 \\
\hline \multicolumn{5}{|l|}{1505} \\
\hline 1595 & & 1599 & 1599 & 1600 \\
\hline 1614 & 1614 & 1618 & 1618 & \\
\hline 1674 & & & & \\
\hline
\end{tabular}


A táblázatban ugyanakkor az is látható, a polisztirolén kívül további sávok is megjelennek az SA minta SERS-spektrumában 1292, 1505 és $1674 \mathrm{~cm}^{-1}$-nél. Ezek a fluoreszcens molekulákhoz és a minta felületén található karboxilcsoportokhoz rendelhetők. Megjelenésük - különösen a felületi karboxilcsoport esetében - egyértelműen a SERSerősítésnek köszönhető. A polisztiroltól eltérő sávok az ST minta SERS-spektrumában is beazonosíthatók 1084 és $1110 \mathrm{~cm}^{-1}$-nél.

Egy csapdázott SA mikrogömbön annak $1600 \mathrm{~cm}^{-1}$-nél található Raman-csúcsának hullámszámértékén térképes Raman-méréseket is végeztem. A 46. ábra a csapdáról készített optikai mikroszkópos képeket, valamint a Raman-intenzitástérképet mutatja. Bár maga a mikrogömb a kis mérete és az alkalmazott objektív kis mélységélessége miatt nem látható a fotón, a jelenléte az üregnek a szomszédosokétól eltérő megjelenése miatt így is észlelhető. A Raman-intenzitástérkép jól illeszkedik az üreghez, de a mikronos laterális felbontás miatt a 2 $\mu \mathrm{m}$ gömb esetében csak néhány mérési pontból tartalmaz adatokat.
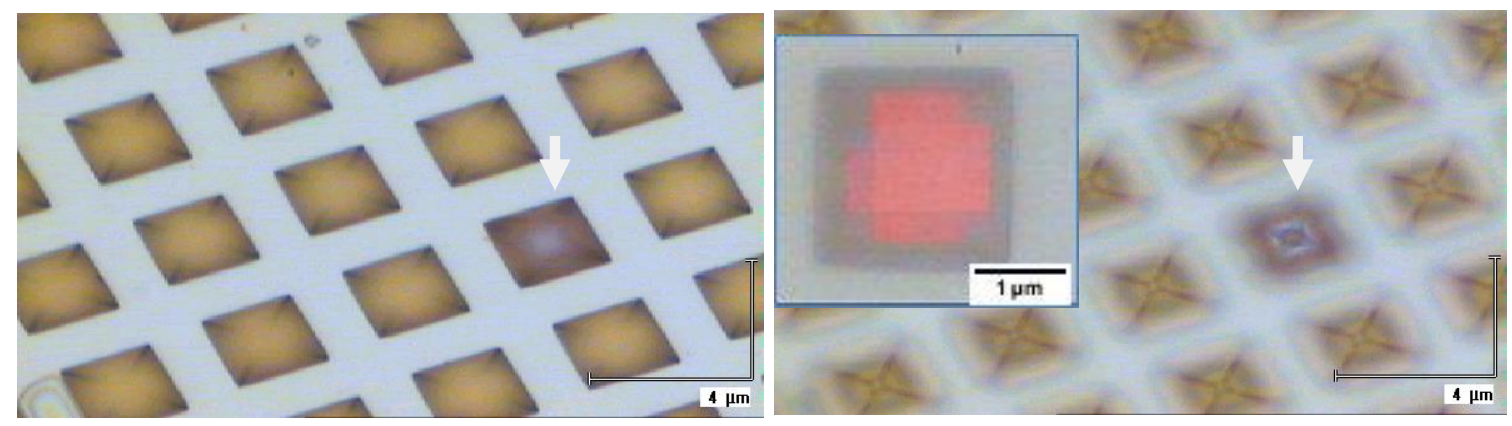

46. ábra: Csapdázott SA mikrogömb optikai mikroszkópos képe két fókuszmélységnél. A jobb oldali képen a betét a Raman-intenzitástérképet mutatja a cella optikai mikroszkópos képére vetítve.

\subsubsection{Vörösvérsejtek csapdázása és SERS-vizsgálata}

A 2,2×2,2 $\mu \mathrm{m}$ méretű átfolyásos SERS-hordozón szerzett tapasztalatokat felhasználva vörösvértestek (RBC) csapdázására alkalmas hordozót is terveztünk. Az RBC-k mérete 6-8 $\mu \mathrm{m}$ körüli, ezért az átfolyásos struktúra méreteit ennek megfelelően kellett megválasztani. A felső nyílás méretét 12 mikronra, az alsót 6 mikronra állítottuk be. Hordozóként 5 mikron vastagságú SOI-t használtunk. A struktúra vázlatos geometriáját a 47. ábra mutatja. 


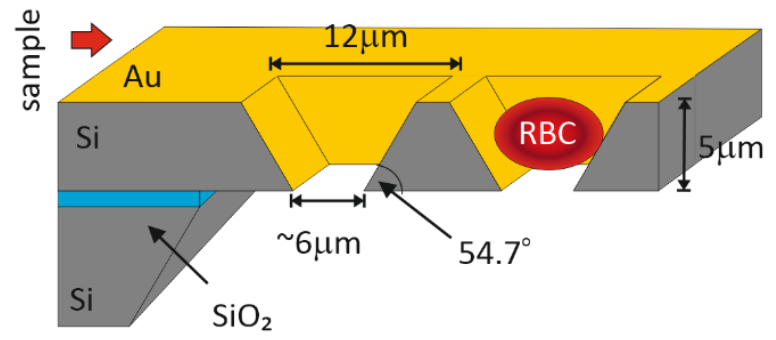

47. ábra: Átfolyásos SERS-hordozó vázlatos geometriája csapdázott vörösvérsejttel.

A fotolitográfia és anizotrop marás után kapott hordozó SEM-képeit a 48. ábra mutatja. Ebben a mérettartományban már nagyon jó minőségü felületeket lehet előállítani, az üregek alakja és mérete is egységes. A SERS-aktivitás érdekében erre a hordozóra is $150 \mathrm{~nm}$-es aranyréteg került.

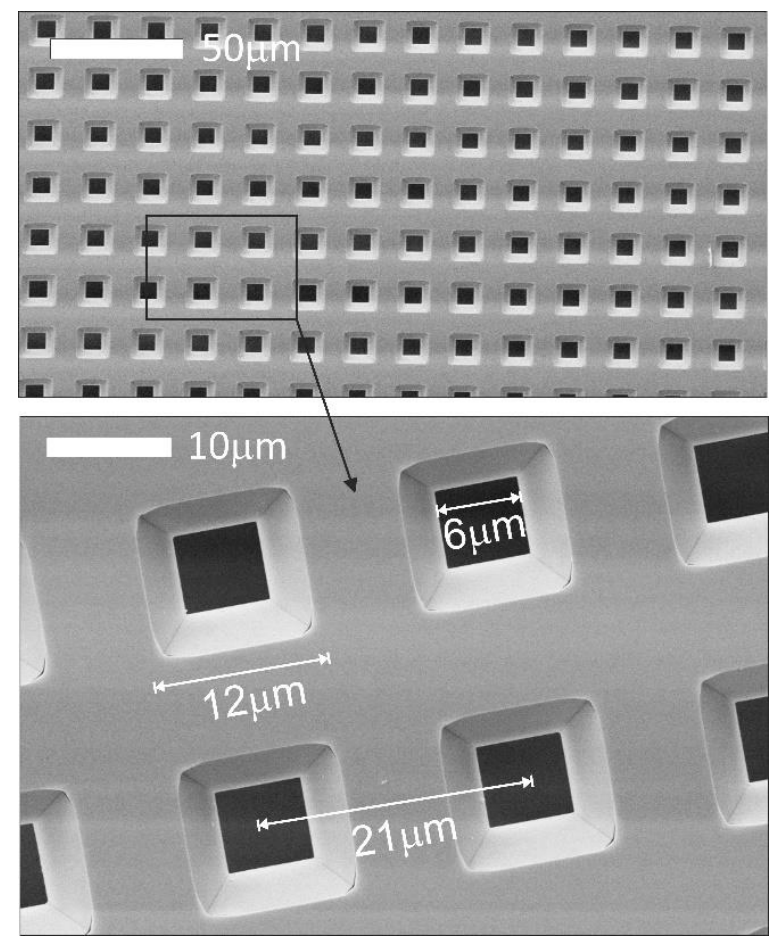

48. ábra: A vörösvérsejtek csapdázására tervezett átfolyásos SERS-hordozó SEM-képei a föbb méretekkel.

A hotspotok elhelyezkedésének meghatározására ezen a szerkezeten is végeztem FDTD-szimulációt. Amint a 49. ábrán látható, a hotspotok a polarizáció irányára merőleges oldalakon lokalizálódnak, a legintenzívebb, de kis kiterjedésü területek az alsó nyílás élein vannak (felső sor). Nagyobb kiterjedésủ térerősség-növekedés figyelhető meg kicsivel az alsó nyílás síkja fölött. A térerősség maximális értéke 6 (meg kell jegyezni, hogy mindegyik ábrához relatív intenzitásskála tartozik, amelyen a sötétvörös színhez az adott eloszlási térkép 
legnagyobb, a sötétkék színhez pedig a legkisebb értéke tartozik). A 49. ábra alsó sorában az intenzitás alapján kapott maximális erősítési faktor eloszlása látható.

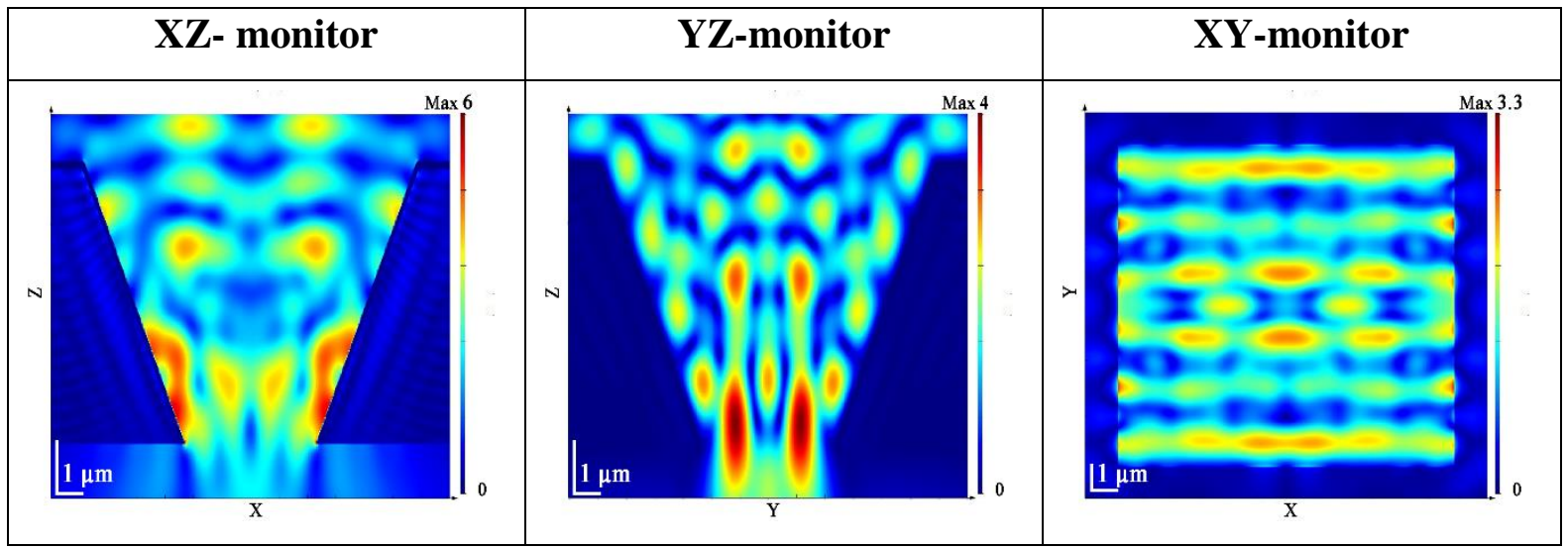

49. ábra: A vörösvérsejtek csapdázására tervezett átfolyásos SERS-hordozó téreloszlása az $X Z$-, YZ- és XY-monitorsíkokban.

Az FTDT-szimulációval kapott reflexiós spektrum alakja nagyon hasonló az előző részben ismertetett átfolyásos hordozóéhoz. Itt is egy nagyon keskeny (12 nm-es szélességü), ugyanakkor intenzív reflexiócsökkenés figyelhető meg 640 nm-nél.

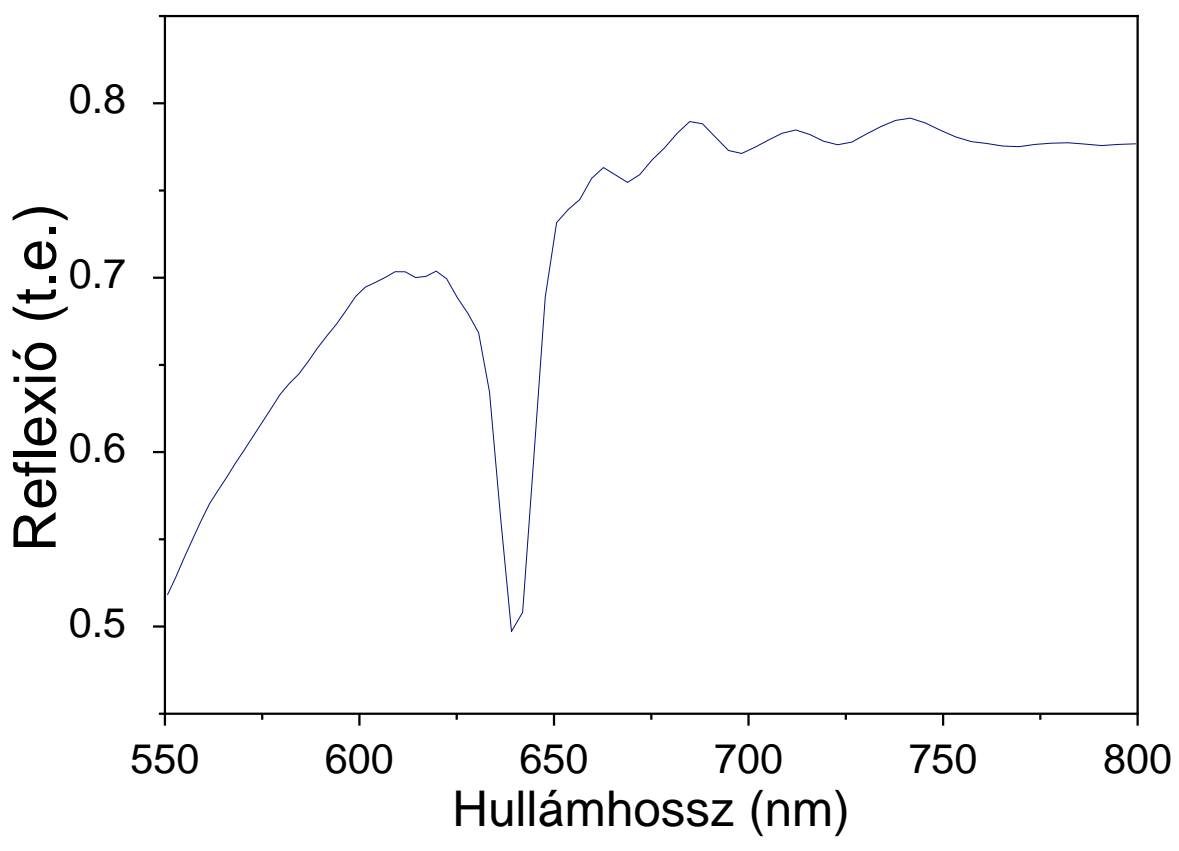

50. ábra: A SERS-hordozó modellezett reflexiós spektruma.

Vörösvérsejteket és vérplazmát is tartalmazó vérmintát cseppentéses módszerrel helyeztem el a hordozón. Az RBC minta elhelyezése során azt tapasztaltam, hogy a hordozó méretei éppen alkalmasak a vérsejtek megtartására, ugyanakkor már kis erőhatás, például az üregeken át egy öblítés során kialakuló folyadékáram is képes átjuttatni az RBC-ket a hordozón. Emiatt a hordozó méreteit a későbbiekben csökkenteni kell. 
Amint a SEM-felvételen látható, több üregbe is sikerült RBC-ket csapdázni. Ugyanakkor további sejtek tapadtak ki a hordozó üregeken kívüli részein is, mivel nem történt öblítés a szuszpenzió rácsöppentése után. Megjegyzendő, hogy az 51. ábrán látható SEMfelvételek elkészítéséhez az átfolyásos hordozót egy tiszta szilíciumlapkára helyeztem. Mivel az gátolta az átfolyást, az RBC-k nem tudtak kimosódni az üregekből. A hordozó üregeibe vérplazma is beszáradt, így a vörösvértestek mellett a hordozón a vérplazma SERS-spektrumát is rögzíteni tudtam.

A vérplazma és egy RBC a hordozó üregen kívüli részén (rendre az R1 és R3 pontokban, 51. ábra) felvett normál Raman-, valamint üregekben (rendre az R2 és R4 pontokban, 51. ábra) rögzített SERS-spektrumokat az 52. ábra hasonlítja össze.
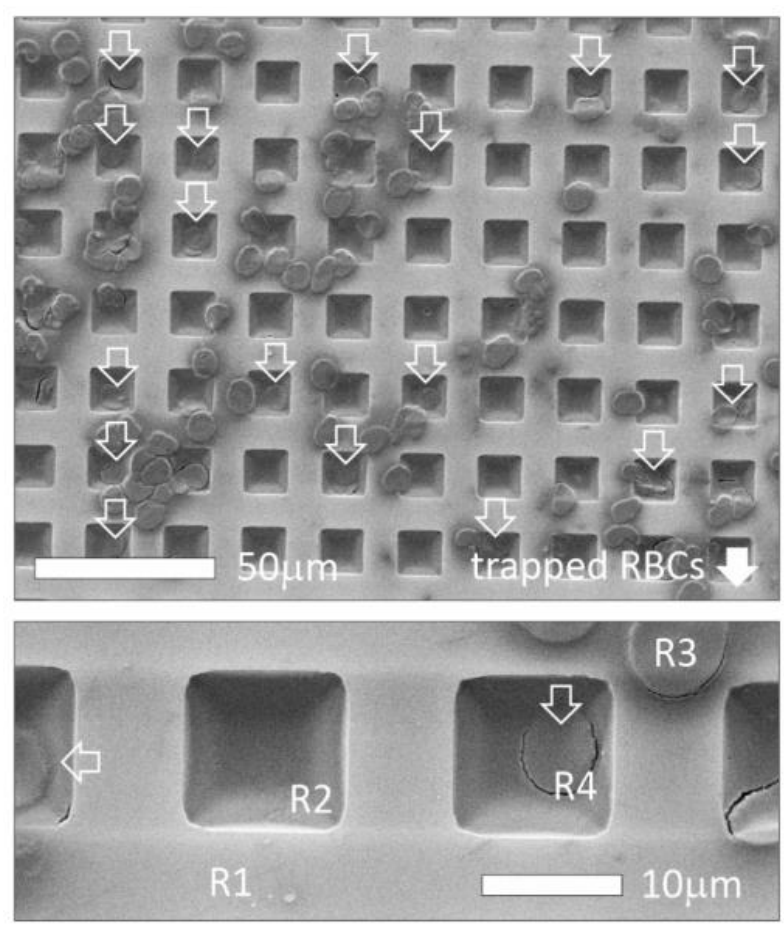

51. ábra: A SERS-hordozón csapdázott RBC-k SEM-képei. A fehér nyilak a csapdázott vörösvérsejteket jelzik, az R1, R2, R3 és R4 jelölések pedig a SERS-mérések helyét mutatják.

Mindkét minta normál Raman-spektrumában több Raman-csúcs is megfigyelhető, melyek között egyezések is elöfordulnak.

A hemoglobin a RBC-k szárított tömegének több mint 95\%-át teszi ki, amely nagyon erős Raman szórást mutat, így mind a vörösvértest, mind a teljes vér Raman spektrumát a hemoglobin sávok dominálják, melyeket az alábbi 5. táblázatban foglalok össze a következő irodalmi források [133 - 136] alapján. 
5. táblázat: A hemoglobinra vonatkozó sávok helyzete és a megfelelö koordináták / rezgések hozzárendelések.

\begin{tabular}{|c|c|}
\hline Raman-csúcs pozíció, cm-1 $^{-1}$ & Rezgés \\
\hline 419 & $\delta(\mathrm{Fe}-\mathrm{O}-\mathrm{O})$ \\
\hline 567 & $v\left(\mathrm{Fe}-\mathrm{O}_{2}\right)$ \\
\hline 673 & $\delta$ (pirrol deformációs) \\
\hline 754 & $v$ (pirrol lélegző) \\
\hline 789 & $v$ (pirrol lélegző) \\
\hline 827 & $\gamma\left(\mathrm{C}_{\mathrm{m}} \mathrm{H}\right)$ \\
\hline 974 & $\gamma\left(\mathrm{C}_{\mathrm{a}} \mathrm{H}=\right)$ \\
\hline 993 & $v\left(\mathrm{C}_{\mathrm{b}} \mathrm{C}_{1}\right) \mathrm{AS}$ \\
\hline 1002 & Fenil-alanin \\
\hline 1082 & $\delta\left(=\mathrm{C}_{\mathrm{b}} \mathrm{H}_{2}\right)_{4}$ \\
\hline 1127 & $v\left(\mathrm{C}_{\mathrm{b}}\right.$-methyl $)$ \\
\hline 1156 & $v$ (pirrol félgyürü) \\
\hline 1174 & $v$ (pirrol félgyürü) \\
\hline 1207 & $\delta\left(\mathrm{C}_{\mathrm{m}} \mathrm{H}\right)$ \\
\hline 1222 & $\delta\left(\mathrm{C}_{\mathrm{m}} \mathrm{H}\right)$ or $\mathrm{Eu}$ \\
\hline 1356 & $v$ (pirrol félgyürü) \\
\hline 1371 & $v$ (pirrol félgyürü) \\
\hline 1448 & $\delta\left(\mathrm{CH}_{2} / \mathrm{CH}_{3}\right)$ \\
\hline 1526 & $v$ (pirrol lélegző) \\
\hline 1547 & $v\left(\mathrm{C}_{\mathrm{b}} \mathrm{C}_{\mathrm{b}}\right)$ \\
\hline 1566 & $v\left(\mathrm{C}_{\mathrm{b}} \mathrm{C}_{\mathrm{b}}\right)$ \\
\hline 1582 & $v\left(\mathrm{C}_{\mathrm{a}} \mathrm{C}_{\mathrm{m}}\right)$ \\
\hline 1620 & $v\left(\mathrm{C}_{\mathrm{a}}=\mathrm{C}_{\mathrm{b}}\right)$ \\
\hline 1639 & $v\left(\mathrm{C}_{\mathrm{a}} \mathrm{C}_{\mathrm{m}}\right)$ \\
\hline 1653 & Amid I \\
\hline
\end{tabular}

A hemoglobin csúcspozícióján kívül több más biomarkert is megfigyelhetünk, melyeknek karakterisztikus rezgéseit az 6. táblázat foglalja össze az irodalmi hivatkozásokra támaszkodva [133 - 138]. 
6. táblázat: A vérben fellelhetö egyéb markerekre vonatkozó Raman sávok helyzete és a megfelelö markerek neve, rezgésének típusa.

\begin{tabular}{|c|c|}
\hline Raman-csúcs pozícióa, $\mathbf{c m}^{-1}$ & Rezgés \\
\hline 640 & A tirozin proteinek C-S nyújtása és C-C csavarása \\
\hline 675 & Amid I \\
\hline 700 & $v(\mathrm{C}-\mathrm{S})$ transzlációs (aminosav metionin) \\
\hline $714-716$ & $\begin{array}{l}\text { C-N (membrán foszfolipidek feje) / adenin } \\
\qquad \mathrm{CN}_{2}\left(\mathrm{CH}_{3}\right)_{3} \text { (lipidek) }\end{array}$ \\
\hline 752 & Gaunin \\
\hline 761 & Triptofán, $\delta$ (gyürü) \\
\hline 770 & Foszfát \\
\hline 778 & Foszfatidilinozitol \\
\hline 788 & Foszfodiészter sávok a DNS-ben \\
\hline 798 & A CH síkból kilépő deformációja \\
\hline 828 & tirozin / fehérje \\
\hline 885 & Diszacharid (cellobióz), (C-O-C) \\
\hline 901 & Monoszacharidok (b-glükóz) \\
\hline 917 & Prolin, hidroxi-prolin \\
\hline 1138 & $v(\mathrm{C}-\mathrm{C})$-lipidek, zsírsavak \\
\hline 1145 & $v(\mathrm{C}-\mathrm{C})$-lipidek, zsírsavak \\
\hline 1173 & Citozin, guanin \\
\hline 1185 & Antiszimmetrikus foszfát rezgések \\
\hline 1268 & $\delta(=\mathrm{C}-\mathrm{H})$ (foszfolipidek) \\
\hline 1285 & Tipikus foszfolipidek \\
\hline 1307 & $\begin{array}{c}\mathrm{CH}_{3} / \mathrm{CH}_{2} \text { csavarási, vagy hajlítási mód } \\
\text { kollagének és lipidek }\end{array}$ \\
\hline 1319 & Guanin \\
\hline 1440 & $\mathrm{CH}_{2}$ deformáció \\
\hline 1609 & Citozin $\left(\mathrm{NH}_{2}\right)$ \\
\hline 1663 & DNS \\
\hline
\end{tabular}

Az irodalmi összefoglaló elemzésben interpretálják a megfelelő csúcsok hozzárendeléséhez szükséges adatokat [139, 140]. Megállapítható, hogy a két spektrumon egyértelmü különbségek 
figyelhetőek meg az $570 \mathrm{~cm}^{-1}$ (FeO), $670 \mathrm{~cm}^{-1}$ és $750 \mathrm{~cm}^{-1}$ (pirrol), $820 \mathrm{~cm}^{-1}$ és $1550 \mathrm{~cm}^{-1}$ (tirozin és fenilalanin) és az $1227 \mathrm{~cm}^{-1}$ (hemoglobin $\mathrm{CH}$ csoport) csúcsaiban.

Az RBC-n mért spektrumban a vérplazma Raman-sávjai is megjelennek. Ennek két oka lehet: vagy magára a hordozóra vagy az RBC-re (vagy mindkettőre) beszáradt vérplazma, aminek járuléka megjelenik a mért spektrumban. A SERS-spektrum mindkét mintánál intenzívebb és több Raman-sávot is tartalmaz. A nagyobb intenzitás jól mutatja a felületerôsítés megjelenését. Bár a vérplazma esetében előfordulhatna, hogy az üreg alján több minta van és ez okozza a nagyobb intenzitást, az RBC-nél ez nem áll fenn. Ráadásul a SERS-méréseket az üreg arannyal borított ferde oldalfalán, és nem a közepén végeztem, ahova nem ülepedhetett ki nagyobb mennyiségü vérplazma (mivel lefolyik az üreg aljára). Ezen megfontolásokat figyelembe véve az intenzitásnövekedés a SERS-mechanizmus megjelenésének egyik, vagy közvetlen bizonyítéka.
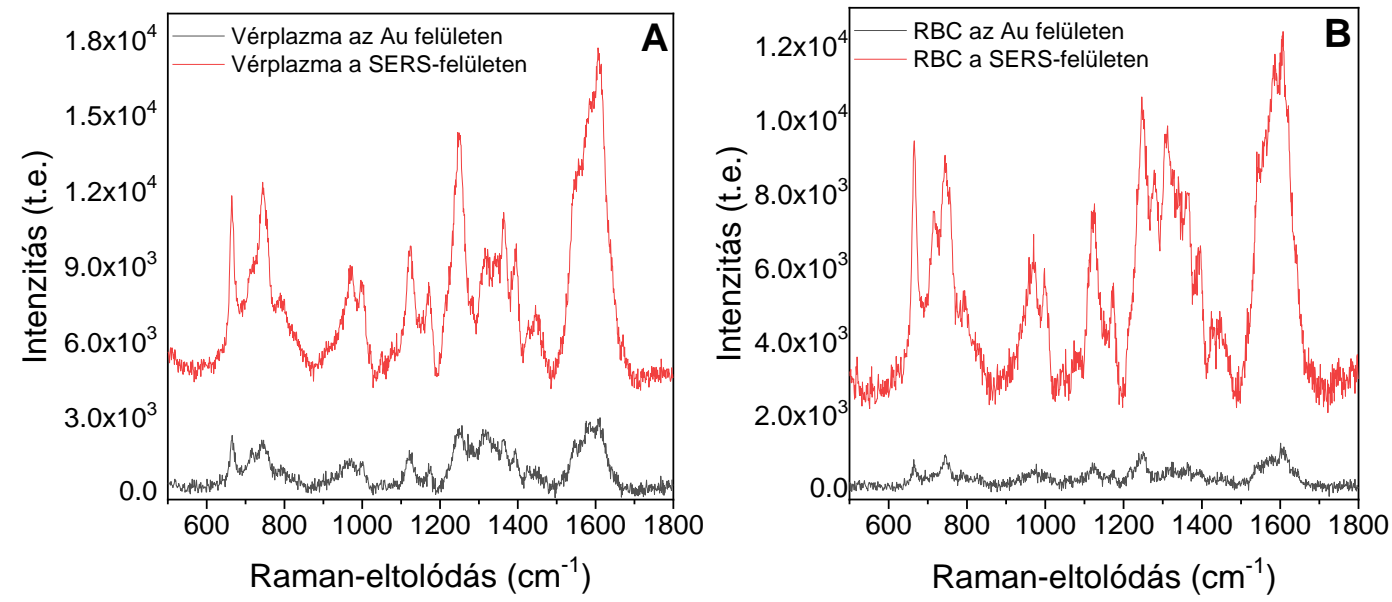

52. ábra: A vérplazmán (bal oldali ábra, R1, R2 mérési pontok az 51. ábrán) és az RBC-ken (jobb oldali ábra, R3, R4 mérési pontok az 51. ábrán) sík arany és strukturált SERS-

felületeken mért Raman-spektrumok.

A vérplazma és az RBC-k SERS-spektrumában látható sávok részletes elemzésére nem szeretnék kitérni a dolgozatban. Megjegyzendő, hogy az itt bemutatott hordozóból csak egy minta készült. Mivel ezzel nem tudtuk hatékonyan csapdázni a vörösvérsejteket, jelenleg folyik egy kisebb méretü üreggel rendelkező SERS-struktúra előállítása. Amennyiben azzal sikerül jól rögzíteni az RBC-ket, megkezdjük a spektrumok jellegzetességeinek részletes feldolgozását is.

Összefoglalásként elmondható, hogy fotolitográfiás technika alkalmazásával sikerült szilícium-szigetelő hordozón mikroszkopikus objektumok csapdázására és felületi funkciós 
csoportjainak SERS-mérésére alkalmas perforált hordozókat készíteni, melyek müködőképességét polimer mikrogömbökön demonstráltam. Az elöállított szerkezetek méretei alapján szerkesztett modellgeometrián végzett FDTD-számításokkal meghatároztam az elektromos téreloszlást és a hotspotok helyzetét. Nagyobb üregméretü átfolyásos hordozókon vörösvérsejtek és vérplazma SERS-spektrumát rögzítettem. Az ilyen plazmonikus struktúrák ígéretes jövőbeni alkalmazása lehet az orvosdiagnosztikában vagy a fotonikus nanosugarak előállításában.

\subsection{Felületerősítés arany nanogömböt tartalmazó inverz piramis SERS-hordozókon}

Az eredmények fejezet első részében bemutatott, különböző morfológiájú üregek alkotta SERS-hordozókon aranykolloiddal kevert benzofenon oldat SERS-spektrumát vizsgáltam, amikor is az egyik üregnél a Raman-intenzitás több nagyságrendnyi megnövekedését tapasztaltam. A szomszédos üregeknél ez nem jelentkezett. További kísérletek azt mutatták, hogy a jelentős intenzitásnövekedés arany nanogömböket tartalmazó celláknál jelentkezik. Ezt követően szisztematikus Raman-méréseket és szimulációkat végeztem a jelenség feltérképezésére. Ezek eredményeit foglalja össze az alábbi fejezet.

Az 53. ábra ugyanazon benzofenon oldat négy, hasonló hordozón mért SERS-spektruma látható. A SERS-hordozók alapja a 6.1. fejezetben bemutatott K2 struktúra, melyekbe 50, 100, 150 és $250 \mathrm{~nm}$-es arany nanogömbök kerültek. A bal oldali ábra az ezeken mért, alapvonalkorrekció nélküli intenzitásokat hasonlítja össze, de külön ábrázoltam az üres K2 hordozón mért SERS-spektrumot is. Az ábrán fekete színnel jelzett, a többihez képest kis intenzitású spektrum egy $50 \mathrm{~nm}$-es nanogömböt tartalmazó inverz piramison került rögzítésre, és intenzitása $10^{5}$ nagyságrendủ. A $100 \mathrm{~nm}$-es gömböt tartalmazó inverz piramis esetében az intenzitás egy nagyságrenddel nő, a $200 \mathrm{~nm}$-es gömbnél pedig további egy nagyságrenddel, $10^{7}$-re emelkedik, a $250 \mathrm{~nm}$-es pedig még ennél is nagyobb. A nanogömbök inverz piramisba helyezése és átméröjének növelése több nagyságrenddel képes megnövelni a felületerösített jel intenzitását. Azaz az üres üreghez képest jóval hatékonyabb felületerősítési geometriát sikerült előállítani. 

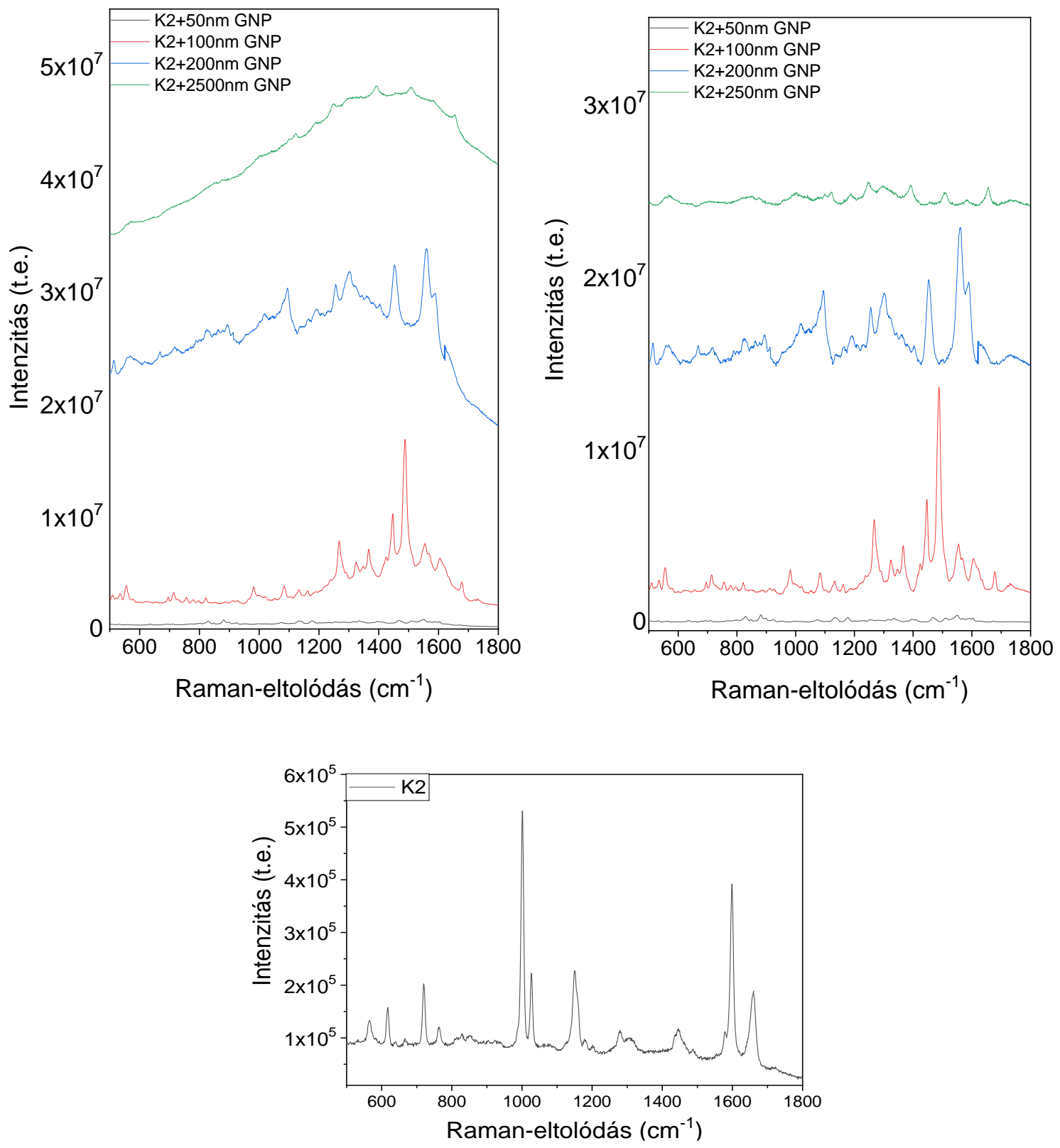

53. ábra: A benzofenon módositás nélküli (bal) és alapvonal-korrigált (jobb) SERSspektrumai különbözö méretü arany nanogömböket tartalmazó inverz piramis alkotta SERShordozókon. (Lent) gömbök nélküli struktúra BP spektruma.

Az 54. ábra egy $200 \mathrm{~nm}$-es aranygömböt tartalmazó inverz piramis SEM-képét mutatja. Amint az várható, a nanogömb az üreg aljában ül. Geometriailag ez egy négyoldalú gúlába helyezett gömbnek felel meg, ami öt pontban érintkezhet a gúla felületével: az alapzat közepén (a mi esetünkben ez nem áll fenn), valamint a négy palást egy-egy pontjában. Feltételezhető az érintkezési pont környezetében, az inverz piramis sík és a nanogömb ívelt felülete között kialakuló, az érintkezési ponttól távolodva egyre szélesebb üregben alakul ki a mért óriási 
felületerősítés. A nanogömb mérete az ívelt felület görbületének változásán keresztül hatással van az erősítés mértékére.
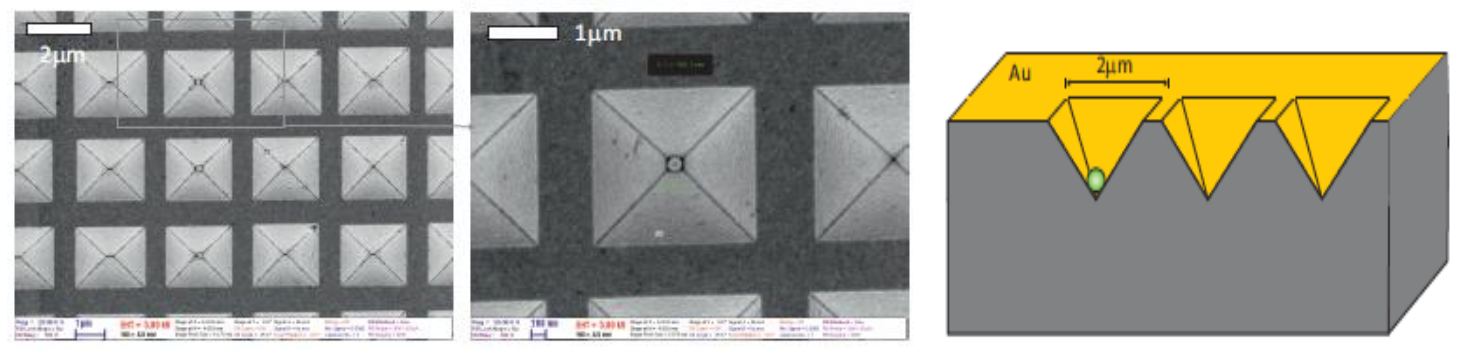

54. ábra: Inverz piramisok alkotta SERS-hordozók üregeibe csapdázódott 200 nm-es arany nanoszemcsék SEM-képei (balra és középen), valamint a hordozó vázlatos geometriája (jobbra).

A kísérletileg meghatározott SE-értékek az 55. ábrán láthatóak. A teljes erősítés a nanogömb méretével szintén növekvő tendenciát mutat.

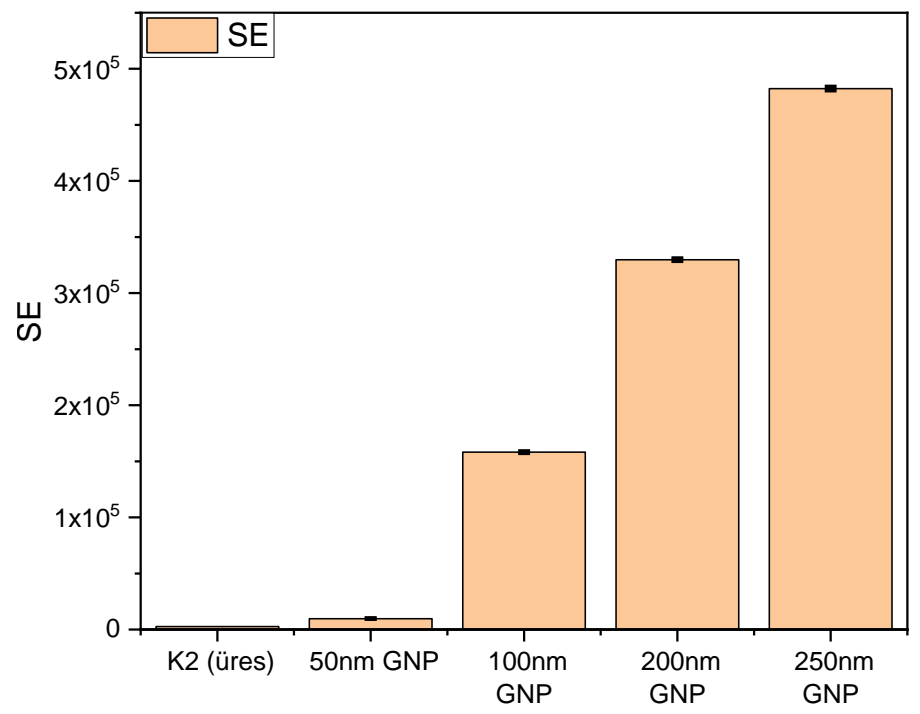

55. ábra: A mérésekböl meghatározott SE-értékek az egy arany nanogömböt tartalmazó mintáknál.

Az 53. ábra alaposabb elemzése arra is rámutat, hogy az intenzitásnövekedés a spektrum minden részére kiterjed: a Raman-sávokra és a háttérre is. Sőt, a Raman-sávok háttérhez viszonyított intenzitása a kezdeti növekedés után folyamatosan csökken az arany nanogömb átmérőjével. Ez jól látható a jobb oldali ábrán, ami a bal oldali spektrumokat mutatja alapvonalkorrekció után. A keskeny sávok a 100 nm-es minta esetében a legintenzívebbek, nagyobb szemcseméreteknél pedig csökkennek. Ismert, hogy a felületerősítés a Raman-szórás mellett például a fotolumineszcenciajel erősítésére is alkalmas [141], abban az esetben, ha a 
minta nem adszorbeálódott a felületre. Itt azonban a fémfelülethez közeledve a felületerősítés hatékonyságának csökkenése tapasztalható, olyannyira, hogy közvetlenül a plazmonikus felületen már nincs is erősítés (mindez kis intezitású hátteret eredményez a SERS számára, ami itt a legintenzívebb). Az 53. ábrán látható spektrumok azt mutatják, hogy az arany nanogömbös struktúra a Raman-szórás mellett a fluoreszcencia-jelet is erősíti, és $100 \mathrm{~nm}$-es szemcseméret felett utóbbi járuléka egyre jelentősebb. A nanogömb átmérőjének növekedésével a gömb ívelt felülete a távolsággal egyre kisebb szögben „távolodik” az inverz piramis felületétől, így nagyobb tartományokra terjednek ki a néhány vagy néhány tíz nanométeres hézagok, amelyekben a fluoreszcenciajel erősítésére is alkalmasak a feltételek. Feltételezhető, hogy ez okozza a flureszcenciajel növekedését az arany nanoszemcse átméröjével összefüggésben.

Az 53. ábráról levonható harmadik következtetés, hogy az egyes spektrumokban megfigyelhető keskeny csúcsok száma, pozíciója és relatív intenzitása nem konzisztens. Adott hordozónál a spektrum alakja nem fluktuál (tehát a jelenség nem SERS blinking [142]), viszont különbség van az egyes hordozókon mért spektrumok között, és hosszabb időtartományban az adott hordozón mért spektrumok között is. A SERS-méréseket friss benzofenon oldattal újra megismételtem, és hasonló eredményt kaptam.

A jelenségnek három oka lehet: a benzofenon oldatban vagy eleve az aranyfelületen nagyon kis koncentrációjú szennyezők vannak, de a tapasztalt erősítés ezek Raman-jelét is detektálhatóvá teszi; hasonló szennyezők az arany nanogömb felületéröl jutottak a hordozóra; a nanogömb felülete és az inverz piramis oldala közötti nanoméretű hézagokban annyira intenzív térgradiensek alakulnak ki, hogy azok hatással vannak a molekulák szerkezetére és polarizáltságára, ami a Raman-csúcsokban is megjelenik.

A Raman-sávok pozíciójának és az intenzitásának megváltozása, új sávok megjelenése nem szokatlan a felületerősített Raman-szórás témakörében. Például a SERS során előforduló blinking-jelenség következtében a mintán rövid integrálási idővel mért Raman-spektrumban a csúcsok fluktuációja figyelhető meg, és a megjelenő sávok sokszor teljes mértékben különböznek a mért minta Raman-csúcsaitól, és utóbbiak egyáltalán nem észlelhetők a spektrumban. A blinking-jelenségnek többféle oka lehet: a molekulák metastabil és nem emittáló állapotba gerjesztése, [143, 144] a molekulák diffúziója a hotspotoknál [145], fotoindukált elektrontranszfer az adszorbeálódott molekula és a SERS-felület között [146], a molekulák orientációjának megváltozása és kémiai reakciók fellépése [147], töltéstranszfer állapotokat érintő fotoionizáció [148] és a SERS felület morfológiájának megváltozása [149]. Mivel a modellezés az inverz gúla fala és a gömb érintkezési pontjának környezetében az üres üregéhez képest jóval nagyobb térerősség-maximumokat mutatott, feltételezhető, hogy a 
blinkinget okozó fenti jelenségek közül több is fellép a gúla és a nanogömb közötti térrészben. Emiatt a Raman-sávok pozíciója és intenzitása is eltérhet a normál Raman-spektrumban megfigyelttől. Bár magát a blinking jelenséget mérések során nem tapasztaltam, a kötött geometria és a molekulák relatíve nagy koncentrációja okozhatja a Raman-jel időbeni változásának csökkenését.

Bár egyértelműen nem azonosítható be, mi a felelős a Raman-csúcsok elmozdulásáért, az első ok szinte biztosan kizárható. Az inverz piramisok azonos körülmények között készültek, a mérésekhez ugyanazt az oldatot használtam, így a szennyezőknek is azonosaknak kellene lenniük, ami a felületerősítés változásával csak a sávok intenzitásának változását eredményezné, megjelenésüket vagy eltünésüket nem. A második okot nem lehet kizárni, esetleg a valószínűsége csökkenthető, ha feltételezzük, hogy ugyanaz a gyártó ugyanazt az eljárást és kiinduló anyagokat használja a különböző méretű arany nanogömbök előállításához. Ebben ez esetben a nanogömb-sík felület plazmonikus struktúrában kialakuló térerősségek és gradiensek miatt jelennek meg új Raman-sávok a spektrumokban.

A térerősség eloszlásának meghatározására FDTD-modellezést végeztem a különböző nanogömb-inverz piramis struktúrákon melyek alapján a SE elméleti értékét is meghatároztam. Megnéztem azt is, mennyire befolyásolja a plazmonikus jellemzőket, ha egynél több rétegnyi aranygömb van az üregben. Megjegyzendő, hogy mindegyik ábrához relatív intenzitásskála tartozik, amelyen a sötétvörös színhez az adott eloszlási térkép legnagyobb, a sötétkék színhez pedig a legkisebb értéke tartozik.

$\mathrm{Az}$ 56. ábra a modellezéssel kapott térerősség-eloszlásokat mutatja a három monitorsíkban, az 57. ábrán pedig ugyanezt felnagyítva az üreg alsó harmadában. Az eredmények összehasonlítása azt mutatja, hogy a térerősség eloszlása mindegyik mintánál azonos az üreg felső részében, ahol nincs nanogömb. Ennek megfelelőn például az XYmonitorsíkban alig figyelhetők meg eltérések. Bár az 50 és 100 nm-es mintáknál ez nem annyira szembetünő, jelentős változások figyelhetők meg a hotspotok eloszlásban az üregek alsó részén. A térerősség fokozatosan egyre inkább a gömbök környezetére koncentrálódik. 


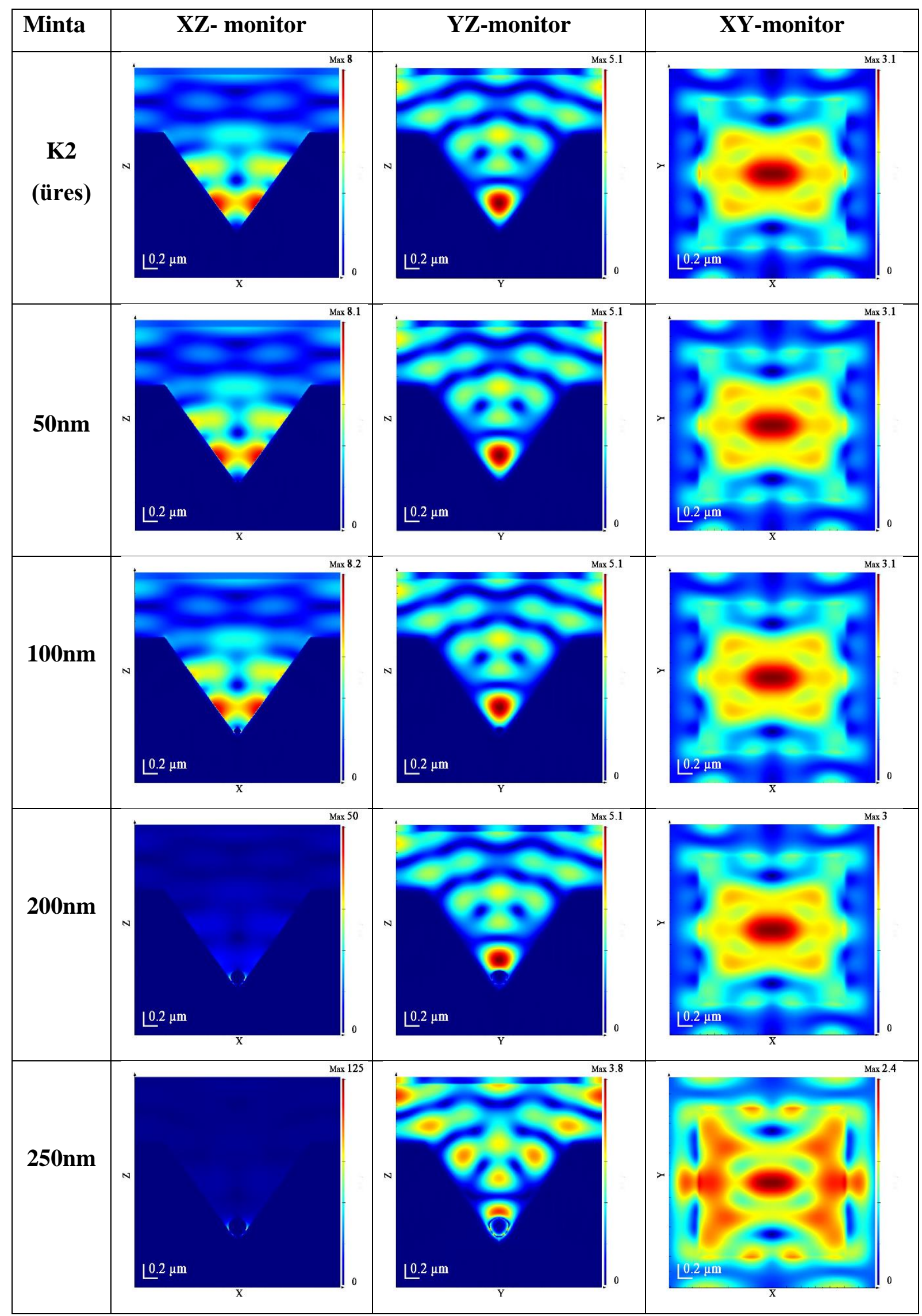

56. ábra: A térerösség eloszlása üres, valamint egy sor 50, 100, 200 és 250 nm-es aranygömböt tartalmazó inverz piramisban. 


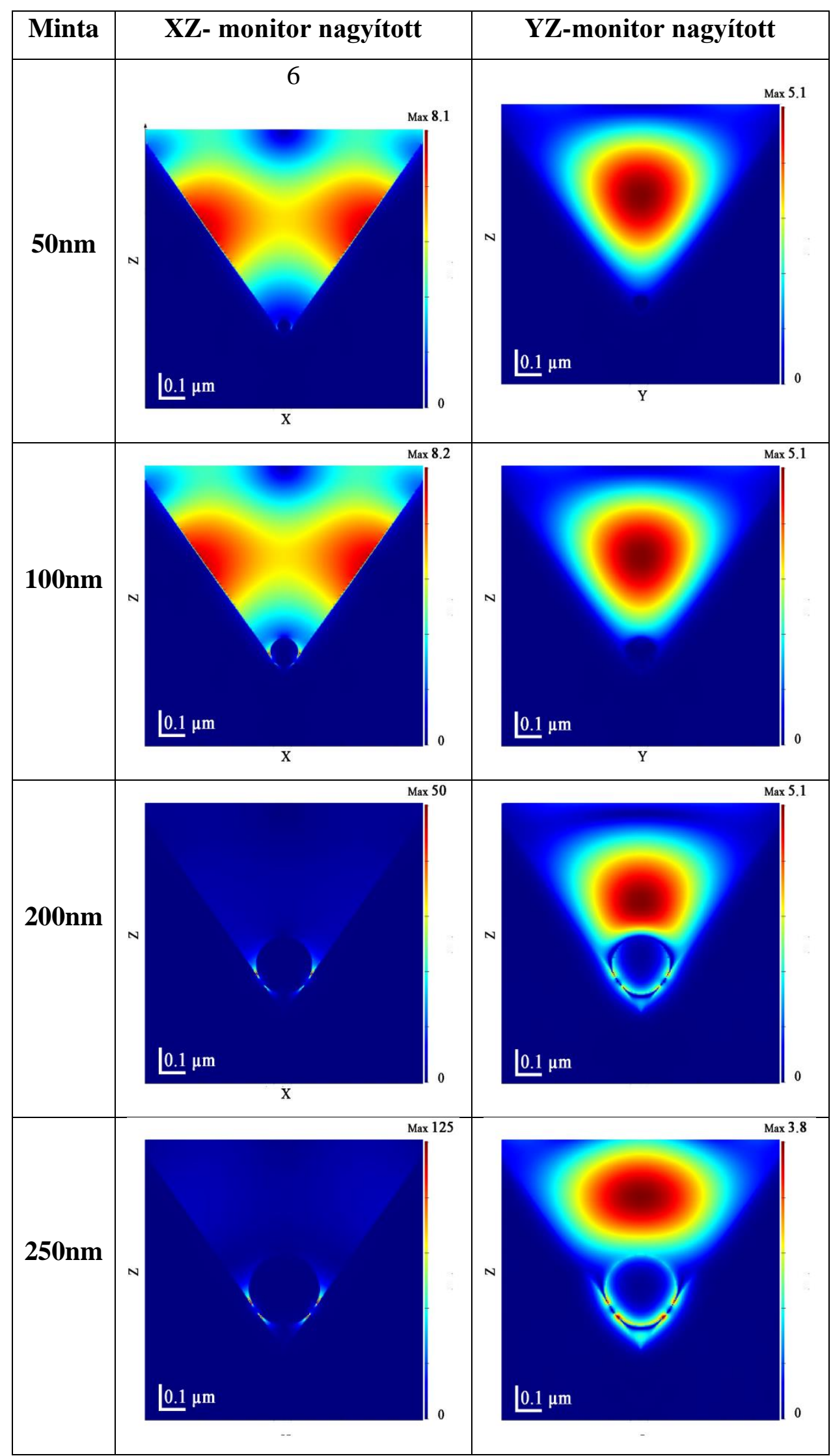

57. ábra: A térerösség eloszlása egy sor 50, 100, 200 és 250 nm-es aranygömböt tartalmazó inverz piramis alsó harmadában. 
A $250 \mathrm{~nm}$-es mintánál például annyira nagy a nanogömb körüli térerösség, hogy az ábrázolás sajátosságai miatt szinte a teljes üreg sötétkék színủ az XZ-monitorsíkban.

Az egyes mintákhoz tartozó elméleti erősítési tényezők értékeit az 58. ábra mutatja.

Összességében a legmagasabb, 125-ös térerösségértéket a $250 \mathrm{~nm}$-es aranygömböt tartalmazó minta mutatja, ami jóval nagyobb, mint az üres inverz piramis - K2 minta a 6.1. fejezetben -8 körüli értéke. Látható, hogy jó egyezés van a modellezett és a mért felületerősítési értékek között, a számított maximális érték az egyes gömbök esetében, nagyon kis térben lokalizálódik, ezért elmarad a mért erősítési értéktől. Az 50 nm-es mintánál a mérésből számított érték kisebb, mint a szimulációval kapott, aminek oka lehet a normál Raman-szórási járulék korrekciós hatása. (lásd 6.1. fejezetben a SERS-erősítés mérési adatokból való meghatározásának nehézségeit).

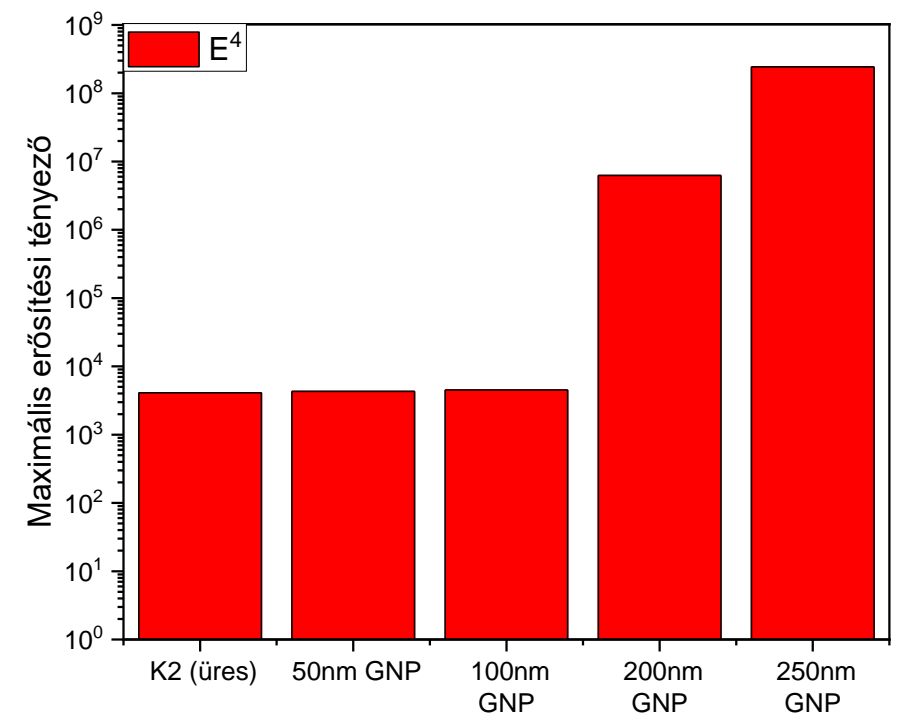

58. ábra: A modellezéssel kapott maximális erösitési tényezök az egy arany nanogömböt tartalmazó mintáknál.

A térerősség növekedése együtt jár a reflexió csökkenésével. Az 59. ábrán látható, hogy a reflexió - föként $800 \mathrm{~nm}$ fölött - csökken a nanogömb átmérőjével, azaz a plazmonrezonancia a nagyobb gömböt tartalmazó mintákban erősebb. Míg az 50 és 100 nm-es mintákhoz tartozó görbék nagyon hasonlóan változnak - és ezekben is megfigyelhetök a 6.1. fejezetben bemutatott fluktuációk - a 200 nm-es mintánál a reflexiócsökkenés mértéke erősebb, a csökkenések szélesebb hullámhossz-tartományokra terjednek ki. A $250 \mathrm{~nm}$-es mintánál a reflexióváltozás mértéke a 200 nm-es mintához tartozó érték többszöröse, és 800-900 nm közötti teljes tartományra kiterjed. A $800 \mathrm{~nm}$ feletti hullámhossztartomány kifejezetten jónak mondható az általam is alkalmazott 785 nm-es gerjesztési hullámhosszal való alkalmazásra. 


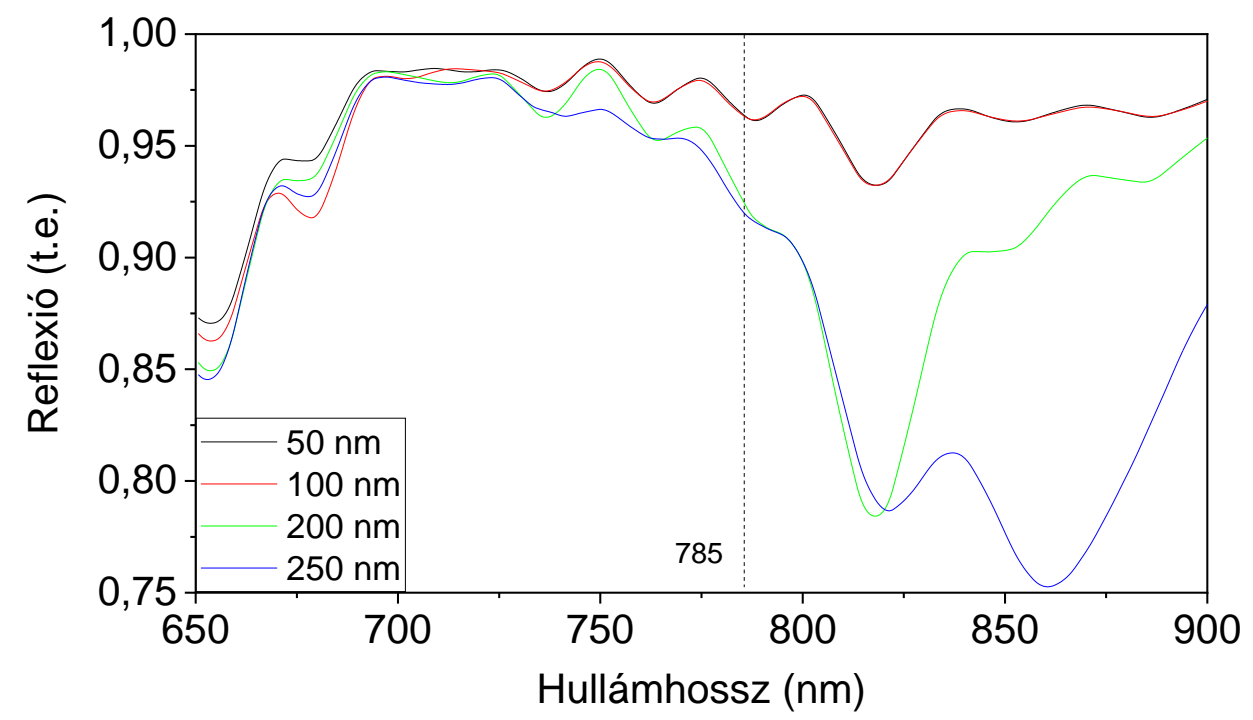

59. ábra: A modellezéssel kapott hullámhosszfüggö reflexió az egy arany nanogömböt tartalmazó mintáknál.

FDTD-modellezéssel megvizsgáltam azt is, hogyan változik a térerősség eloszlása, valamint az elméleti erősítési tényező az egymás fölött két réteg arany nanogömböt tartalmazó szerkezeteknél. A négyoldalú gúla belsejébe helyezett gömbből kiindulva könnyen belátható, hogy amennyiben a nanogömböt a gúla csúcsához toljuk, alatta, a második sorba négy gömböt lehet elhelyezni. Az ilyen struktúrákon kapott téreloszlásokat a 60. ábra mutatja, a 61. ábrán pedig ugyanezt felnagyítva az üreg alsó harmadában. A gömböktöl távol, azaz az XYmonitorsíkban a téreloszlás az egygömbös szerkezetekhez hasonlóan nem igazán változik. A nanogömbök számának növekedésével viszont jóval nagyobb mértékủ a térerősség ezek környezetében való lokalizációja: az XZ-monitorsíkban a 200 és 250 nm-es, az YZ-ben viszont mindegyik minta esetében az üregek alján látható a maximum, és az üreg többi részén - a lineáris intenzitásskálával való ábrázolás sajátossága miatt - alig figyelhető meg intenzitás. 


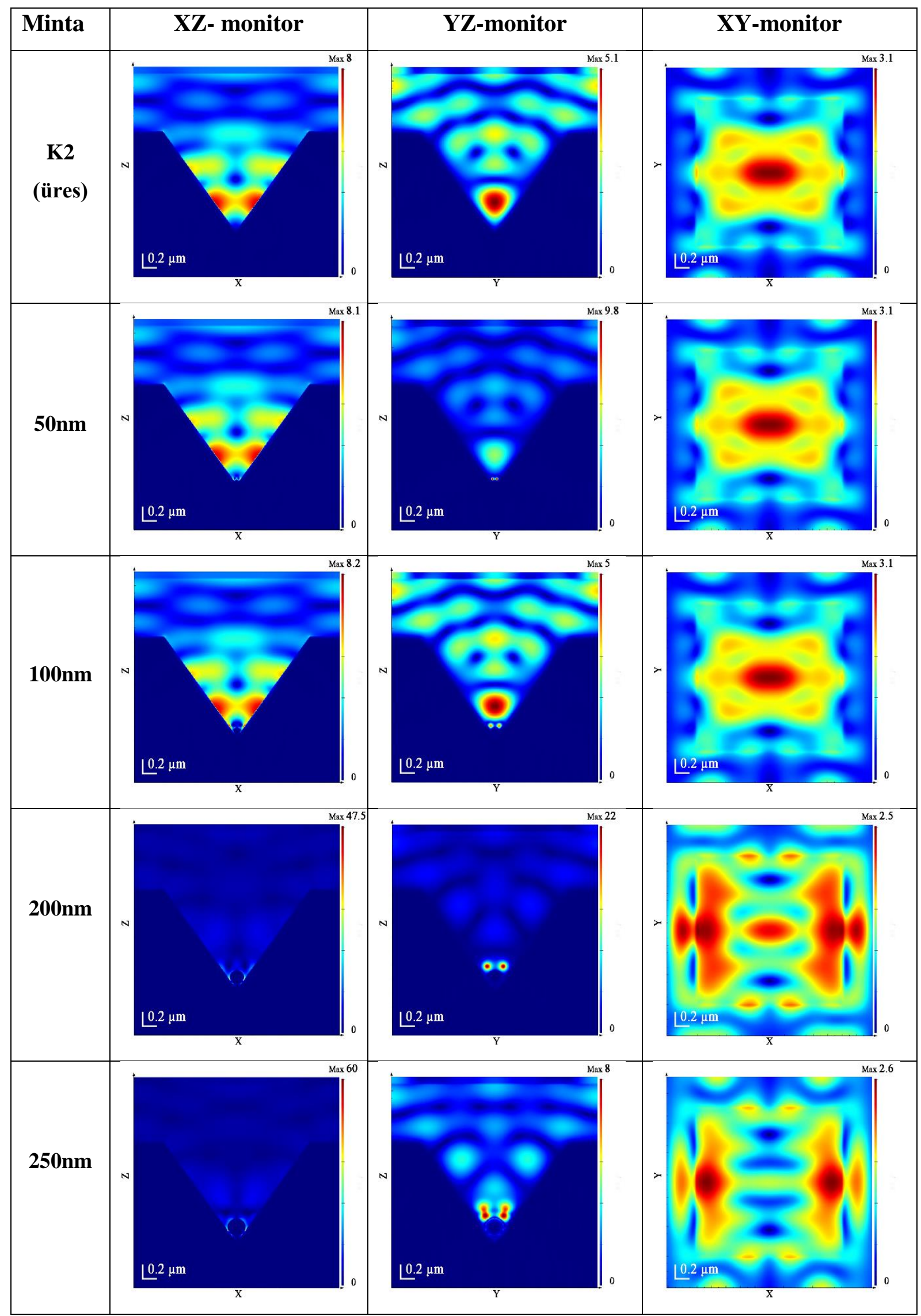

60. ábra: A térerösség eloszlása üres és két réteg 50, 100, 200 és 250 nm-es aranygömböt tartalmazó inverz piramisokban. 


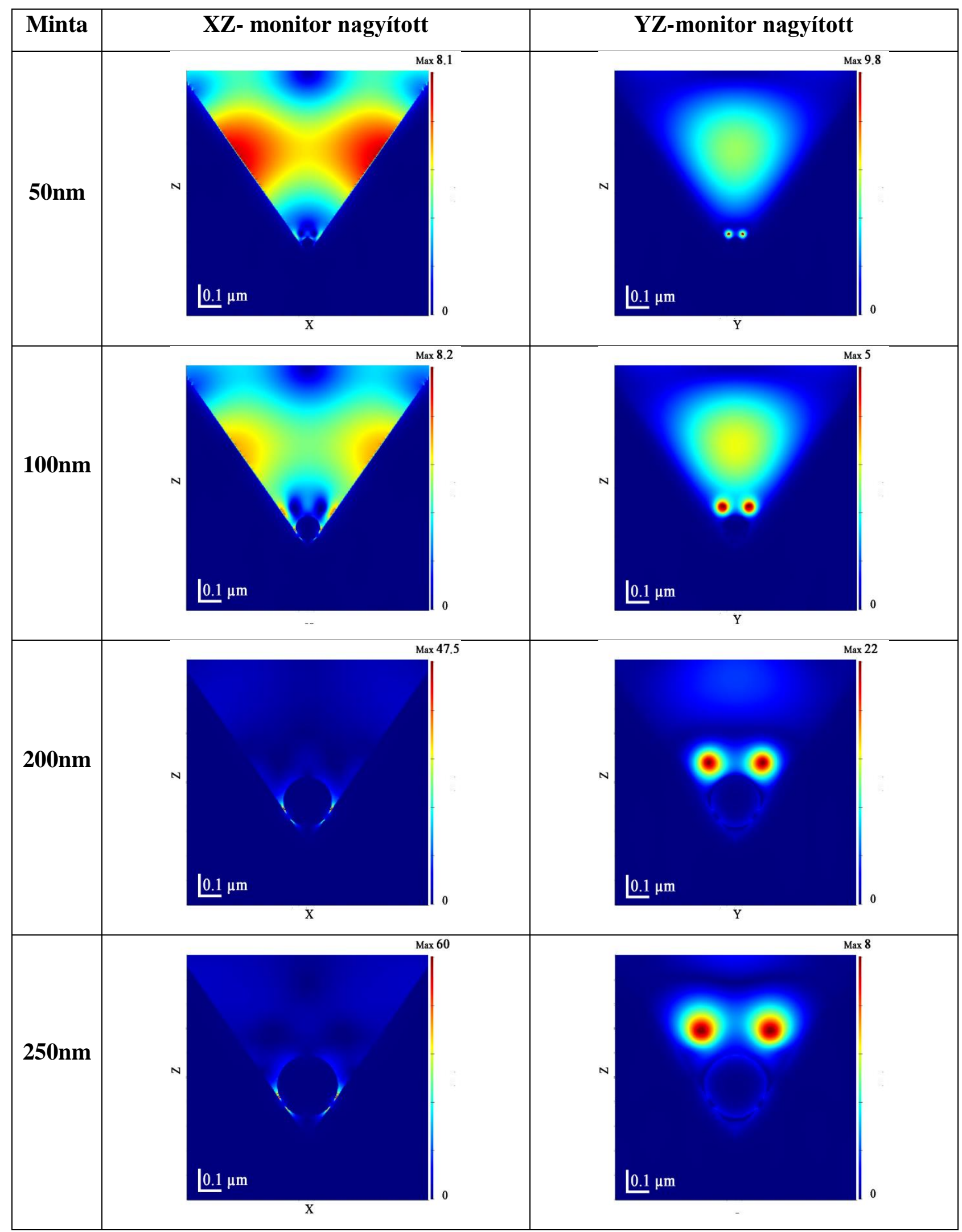

61. ábra: A térerösség eloszlása két réteg 50, 100, 200 és 250 nm-es aranygömböt tartalmazó inverz piramisok alsó harmadában 
A maximális térerősségek értékei és változása a nanogömb méretével hasonló az egy gömböt tartalmazó inverz piramisoknál kapott adatokhoz (58. és 62. ábra).

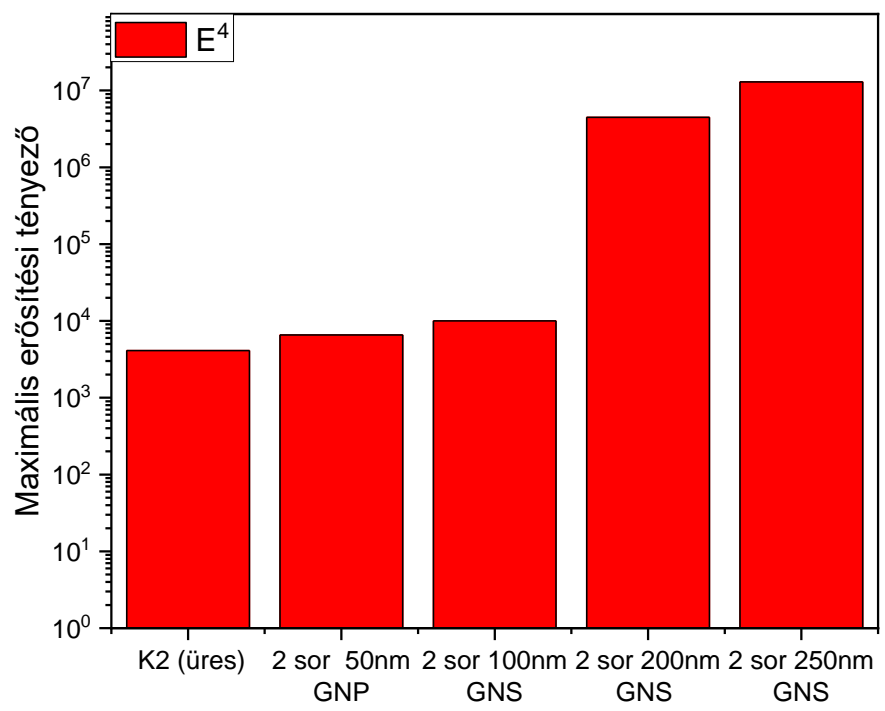

62. ábra: A modellezéssel kapott maximális térerösségek a két sor arany nanogömböt tartalmazó mintáknál.

A reflexiós spektrumok változása is hasonló az egy nanogömböt tartalmazó mintákon tapasztaltakhoz. Az 50 és 100 nm-es minták görbéi hasonlóan változnak, ezeknél hangsúlyosabb a 200 nm-es minta reflexiócsökkenése (63. ábra). Ebben egy keskeny és nagyon intenzív plazmonrezonancia-csúcs jelenik meg $765 \mathrm{~nm}$ körül. A $250 \mathrm{~nm}$-es minta pedig itt is 800-900 nm körül mutat eröteljes csökkenést, aminek hullámhossz-tartománya kisebb, mint az egysoros mintáé. 


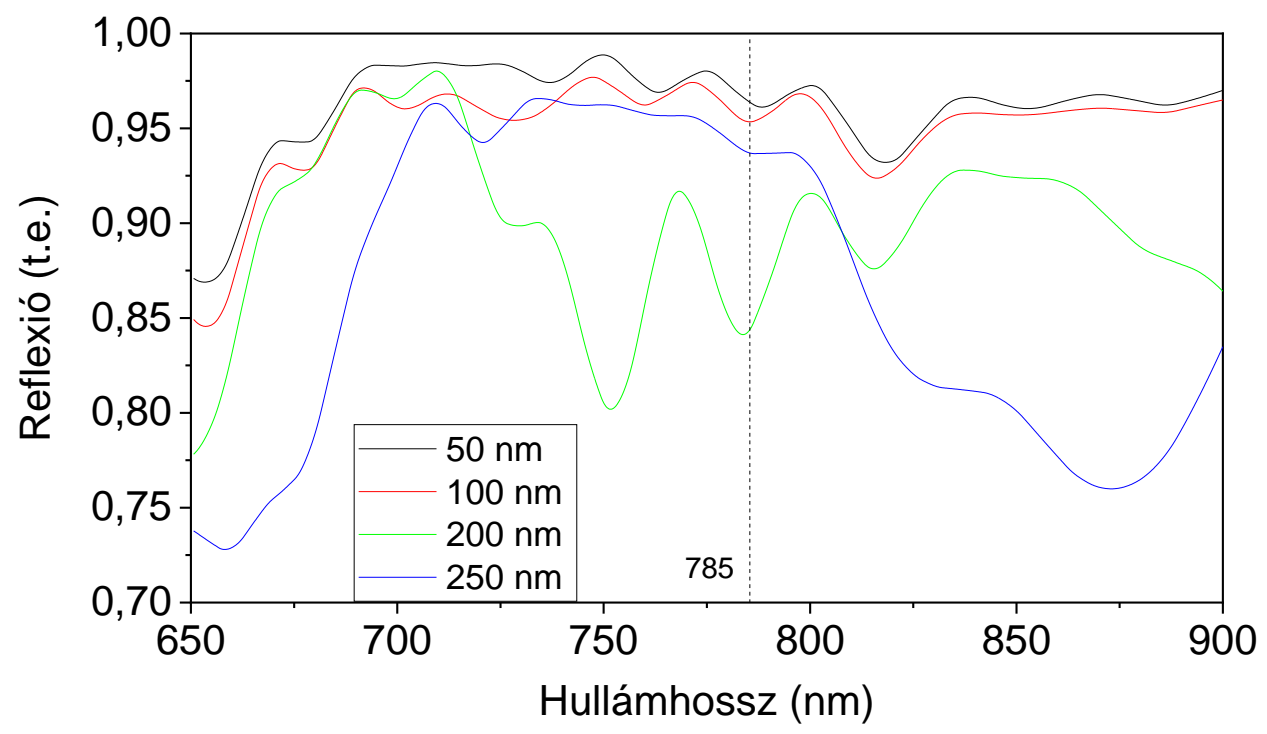

63. ábra: A modellezéssel kapott hullámhosszfüggö reflexió a két arany nanogömböt tartalmazó mintáknál.

A kapott eredmények azt mutatják, hogy a kétféle SERS-hordozótípus, azaz az arany nanogömb és a periodikus morfológiájú felület kombinálása jelentősen megnövelheti a felületerősítés hatékonyságát. A gyakorlati alkalmazás szempontjából megoldandó probléma a nanogömbök megfelelő rögzítése az üregek belsejében. Az egyszerű gravitációs megoldásnál a gömbök könnyen kimoshatók a felületről. A rögzítés azért is fontos, mert az arany nanogömbök perforált hordozókkal való kombinálása lenne igazán hatékony az óriási térerősítés folyadékon és gázmintákon való alkalmazására. 


\section{6. ÖSSZEFOGLALÓ}

A felületerősített Raman-szórás intenzíven kutatott tudományterület, melyen a fókusz egyre inkább a gyakorlati alkalmazások és az új SERS-hordozók kifejlesztése felé tolódik. Napjainkban egy SERS-hordozónak az elérhető legnagyobb erősítési tényező biztosítása mellett sokszor más funkciót is biztosítania kell, például a mérni kívánt objektumok csapdázását. Doktori munkám keretében ilyen, felületerősített Raman-szórásra alkalmas többfunkciós hordozókkal foglalkoztam. Az általunk tervezett, létrehozott és vizsgált struktúrák inverz jellegük miatt meghatározott mérettartományban képesek mikroobjektumok csapdázására, míg a perforált minták akár azok folyadékokból való kiszürésére is.

A fotolitográfia és az izotrop/anizotrop marás nyújtotta mintakészítési lehetőségeket felhasználva készített SERS-hordozókon kísérleti SERS-méréseket és modellszámításokat is végeztem. Az üregek alkotta minták SERS-erősítési mechanizmusának alaposabb megértése érdekében a SEM-képekről és fehérfényü interferometriás adatokból kapott méretekkel reprodukáltam a hordozók felületét, és azokon FDTD-szimulációval meghatároztam a térerősség eloszlását.

A zárt üregek alkotta SERS-hordozóba nehezen jut be a mérendő minta. Az átfolyásos SERS-hordozóknál viszont a méretek jó megválasztásával elérhető, hogy az objektumok bejussanak az üregekbe, és ott csapdázódjanak. Munkám során két ilyen hordozót is vizsgáltam, amelyeket polimer mikrogömbök és vörösvértestek csapdázására és SERS-spektrumainak rögzítésére használtam. Ezeknél is modelleztem az elektromos téreloszlást a polikromatikus síkhullámmal való kölcsönhatás során.

Kutatásaim során kimutattam, hogy arany nanogömbök inverz piramisba helyezése és átmérőjének növelése több nagyságrenddel képes megnövelni a felületerősített jel intenzitását, azaz így az üres üreghez képest jóval hatékonyabb felületerősítési geometria hozható létre. A legnagyobb erősítéseket $200 \mathrm{~nm}$ feletti átmérővel rendelkező nanogömbökkel mértem. Az intenzitásnövekedés a spektrum minden részére kiterjed: a Raman-sávokra és a fluoreszcenciaháttérre is. Modellszámításaim alapján a jelenség mögött a térerősség kicsatolása áll.

Doktori munkám keretében kapott eredményeim megmutatták az üregek mátrixa alkotta SERS-hordozók előnyös tulajdonságait, a hatékonyságot jelentősen megnövelni képes továbbfejlesztési irányok. További kutatómunkám során szeretném kiaknázni az átfolyásos és az arany nanogömböt tartalmazó SERS-hordozókban rejlő ígéretes gyakorlati alkalmazási lehetőségeket. 


\section{Tudományos eredményeimet az alábbi tézispontokban foglalom össze:}

1.1. Szilícium hordozón fotolitográfiával kialakitott, különbözö méretü négyoldalú gúla, lekerekitett élü négyoldalú gúla és félgömb alakú üregek periodikus mintázata alkotta, aranyréteggel bevont hordozók összehasonlitó Raman-spektroszkópiai vizsgálatával kimutattam, hogy a $2 \times 2$ um alapélü négyoldalú gúlák alkotta minta rendelkezik a legnagyobb felületerösitési tényezövel. [I,II]

1.2. Idötartománybeli véges differenciák módszerével végzett modellszámításokkal meghatároztam az elektromos térerösség lokális eloszlását, és azt találtam, hogy annak maximuma a négyoldalú gúláknál az üreg alsó részére koncentrálódik. Az éleket tartalmazó szerkezettöl (négyoldalú gúla) az állandó görbületü felület (félgömb) felé haladva az elektromos térerösség forrópontjainak intenzitása csökken a $2 \times 2 \mu \mathrm{m}$ alapéllel rendelkezö mintáknál. [I,II]

2.1. Optikai mikroszkópiás és pásztázó elektronmikroszkópiás vizsgálatokkal, valamint Raman-spektroszkópiai mérésekkel igazoltam, hogy a szilicium hordozón fotolitográfiával kialakitott, $2 \times 2$ m alapéllel rendelkezö csonka inverz négyoldalú gúla alakú üregek periodikus mátrixa alkotta, aranyréteggel bevont átfolyásos hordozó alkalmas a 2 um-nél és nagyobb részecskék csapdázására és az azok felületén található funkciós csoportok felületerösitett Raman-szórással való vizsgálatára. [III,IV]

2.2. Idötartománybeli véges differenciák módszerével végzett modellszámításokkal kimutattam, hogy a 2 × 2 um alapéllel rendelkezö, aranyréteggel bevont csonka inverz négyoldalú gúla alakú üregben csapdázott 2 um-es polimer mikrogömbnél a térerősség a polimergömb környezetébe koncentrálódik. [III,IV]

3. A felületerösitett Raman-szórás és fluoreszcencia együttes intenzitásának több nagyságrenddel való megnövekedését figyeltem meg $2 \times 2 \mu$ m alapéllel rendelkezö négyoldalú gúla alakú aranybevonatos üregbe helyezett 50-250 nm átméröjü arany nanogömb alkotta komplex struktúráknál. Azt találtam, hogy a felületerösitett Ramanés a fluoreszcenciajel intenzitása növekszik az arany nanogömb méretével. A fenti struktúrákon idötartománybeli véges differenciák módszerével végzett modellezéssel kimutattam, hogy a 200 nm-nél és nagyobb arany nanogömbök esetében a térerösség maximuma az arany nanogömb környezetére lokalizálódik, és a legnagyobb felületerösités a gömb ívelt és az inverz gúla sík felülete közötti szük térrészekben alakul ki. [V,VI] 


\section{SUMMARY}

The new scientific results achieved in my research work are summarized in the following thesis:

1.1. By comparing Raman spectroscopic signals recorded on periodic arrays of cavities of a quadrilateral pyramid, rounded quadrilateral pyramid, and hemispherical shape of different sizes created in silicon wafers, I showed that the quadrilateral pyramidal pattern with two-micrometer base size has the largest SERS enhancement factor. [I,II]

1.2. By performing finite-difference time-domain model calculations, I determined the local distribution of the electric field and the maximum enhancement factor of the investigated structures. I found the field enhancement to be the largest in quadrilateral pyramids, where the maximum is localized at the bottom part of the cavity. Also, the intensity of the hotspots of the electric field decreases when the shape is going from structures with definite edges (quadrilateral pyramids) to surfaces of constant curvature (hemispheres). [I,II]

2.1. By using optical microscopy, scanning electron microscopy and Raman spectroscopy, I demonstrated that a flow-through periodic array of inverse, truncated quadrilateral pyramidal cavities, formed by photolithography on a silicon substrate with a twomicrometer base and covered with a layer of gold, is suitable for entrapment of two micrometer-sized particles, and for surface enhancement Raman amplification of characteristic Raman bands of functional groups residing on the particle surface. [III,IV]

2.2. By performing finite-difference time-domain model calculations I showed that the maximum of electric field enhancement is concentrated at the bottom surface of the two-micrometer sized polymer microsphere entrapped in a gold-coated truncated quadrilateral pyramidal cavity. [III,IV]

3. Several orders of magnitude increase of the Raman scattering and fluorescence intensity was observed in structures formed by entrapping 50-250 nanometer-sized gold nanospheres at the bottom of a gold-plated quadrilateral pyramidal cavity with two-micrometer base. I found that the overall amplification of the intensity of Raman scattering and fluorescence increases with the size of the gold nanosphere. By performing finite-difference time-domain model calculations on these structures, I showed that in structures with $200 \mathrm{~nm}$ sized and larger gold nanospheres the maximum 
of electric field enhancement is localized in the surrounding of gold nanospheres, and the high plasmonic enhancement is concentrated in closed gaps between the curved and planar surfaces of the nanosphere and the inverse pyramid, respectively. [V,VI]

\section{TÉZISPONTOKHOZ KAPCSOLÓDÓ PUBLIKÁCIÓK}

I. István Rigó, Miklós Veres, László Himics, Tamás Váczi, Péter Fürjes; Preparation and Characterization of SERS Substrates of Different Morphology; In Petkov P., Tsiulyanu D., Popov C., Kulisch W. (eds) Advanced Nanotechnologies for Detection and Defence against CBRN Agents, NATO Science for Peace and Security Series B: Physics and Biophysics, Springer, Dordrecht, pp. 63-68 (2019).

II. István Rigó, Miklós Veres, László Himics, Sára Tóth, Aladár Czitrovszky, Attila Nagy, Péter Fürjes; Comparative Analysis of SERS Substrates of Different Morphology; PROCEDIA ENGINEERING 168, 371-374 (2016).

III. István Rigó, István Rigó, Miklós Veres, Péter Fürjes; SERS Active Periodic 3D Structure for Trapping and High Sensitive Molecular Analysis of Particles or Cells; PROCEEDINGS 1(4), 560 (2017).

IV. István Rigó, Miklós Veres, Tamás Váczi, Eszter Holczer, Orsolya Hakkel, András Deák, Péter Fürjes; Preparation and Characterization of Perforated SERS Active Array for Particle Trapping and Sensitive Molecular Analysis; Biosensors 9 (3), 93 (2019).

V. István Rigó, Miklós Veres, Orsolya Hakkel, Péter Fürjes; Hierarchically Combined Periodic SERS Active 3D Micro- and Nanostructures for High Sensitive Molecular Analysis; PROCEEDINGS 2(13), 1069 (2018).

VI. István Rigó, Miklós Veres, Zsuzsanna Pápa, László Himics., Rebeka Öcsi, Orsolya Hakkel, Péter Fürjes; Plasmonic enhancement in gold coated inverse pyramid substrates with entrapped gold nanoparticles. Journal of Quantitative Spectroscopy and Radiative Transfer, 253, 107128 (2020). 


\section{A DOLGOZAT TÉMAKÖRÉHEZ NEM KAPCSOLÓDÓ EGYÉB KÖZLEMÉNYEK}

1) L. Himics, S. Tóth, M. Veres, A. Czitrovszky, A. Nagy, D. Oszetzky, A. Kerekes, S. Kugler, I. Rigó, A. Tóth, and M. Koós, "Creation of blue light emitting color centers in nanosized diamond for different applications," Nato Science For Peace And Security Series A: Chemistry And Biology, vol. 39, pp. 93-10,1 (2015).

2) S. Kugler, A. Kerekes, A. Nagy, I. Rigó, M. Veres, and A. Czitrovszky, "New optical method for MMAD determination of the metered dose inhalators," in European Aerosol Conference, (2015).

3) I. Rigó , A. Czitrovszky, L. Himics, A. Kerekes, S. Kugler, M. Koós, A. Nagy, D. Oszetzky, S. Tóth, T. Verebélyi, and M. Veres, "Determination amount of impactor settled pharmacies with optical microscope methods," in European Aerosol Conference, (2015).

4) A. Kerekes, S. Kugler, A. Nagy, D. Oszetzky, M. Veres, I. Rigó, and A. Czitrovszky, “Az APSD változásának mérése inhalációs készítmények esetében magas páratartalmú környezetben különböző tartózkodási időtartamok mellett," A XII. Magyar Aeroszol Konferencia elöadás-kivonatai, Szeged, pp. 34-35, (2015).

5) I. Rigó, A. Czitrovszky, L. Himics, A. Kerekes, S. Kugler, M. Koós, A. Nagy, D. Oszetzky, S. Tóth, T. Verebélyi, and M. Veres, "Impaktorban kiülepedett gyógyszermennyiségek meghatározása optikai mikroszkópiás módszerekkel”, A XII. Magyar Aeroszol Konferencia elöadás-kivonatai, Szeged, p. 38-39, (2015).

6) S. Kugler, A. Kerekes, A. Nagy, I. Rigó, M. Veres, and A. Czitrovszky, "Kimért dózisú inhalátorok méreteloszlásának meghatározása az új generációs kaszkád impaktorral," in A XII. Magyar Aeroszol Konferencia elöadás-kivonatai, Szeged, pp. 82-83, (2015).

7) S. Tóth, L. Himics, M. Koós, P. Schlosser, T. Verebélyi, I. Rigó, M. Veres, A. Kerekes, A. Nagy, D. Oszetzky, S. Kugler, and A. Czitrovszky, "Különböző aeroszol gyógyszerek fotolumineszcencia módszerrel történő vizsgálata" in A XII. Magyar Aeroszol Konferencia elöadás-kivonatai, Szeged, pp. 93-94, (2015).

8) M. Veres, I. Rigó, L. Himics, T. Verebélyi, S. Tóth, M. Koós, A. Nagy, A. Kerekes, D. Oszetzky, S. Kugler, and A. Czitrovszky, "Measurements of aerosol drug deposition using optical methods," in The 23th International Conference on Advanced Laser Technologies, ALT'15, (2015).

9) A. Kerekes, A. Nagy, M. Veres, I. Rigó, Á. Farkas, and A. Czitrovszky, "In vitro and in silico (IVIS) flow characterization in an idealized human airway geometry using laser Doppler anemometry and computational fluid dynamics techniques," MEASUREMENT, vol. 90, pp. 144-150, (2016).

10) I. Rigó, L. Himics, A. Nagy, A. Czitrovszky, S. Tóth, P. Fürjes, G. Singh, and M. Veres, "Gold-plated silicon nanostructures for surface-enhanced Raman scattering (SERS)," in 17th International Conference "Laser Optics", (2016). 
11) A. Czitrovszky, A. Nagy, M. Veres, A. Kerekes, and I. Rigó, "Complex measurement of aerosol drug deposition using laser methods," in 17th International Conference Laser Optics, (2016).

12) M. Veres, I. Rigó, L. Himics, S. Tóth, A. Nagy, A. Czitrovszky, C. Popov, and V. Ralchenko, "Study of Nitrogen Incorporation into Nanodiamond Films by Multiwavelength Raman Spectroscopy," in 24th Annual International Conference on Advanced Laser Technologies, (2016).

13) I. Rigó, M. Veres, A. Czitrovszky, P. Takács, D. Beke, L. Himics, S. Tóth, and P. Fürjes, "Surface-enhanced Raman scattering of SiC and diamond nanostructures," in 24th Annual International Conference on Advanced Laser Technologies, (2016).

14) A. Nagy, A. Czitrovszky, M. Veres, A. Kerekes, and I. Rigó, "Characterisation of pharmaceutical inhalers and study of pulmonary drug delivery using lasers and optical methods," in 24th Annual International Conference on Advanced Laser Technologies, (2016).

15) L. Himics, M. Veres, S. Tóth, I. Rigó, and M. Koós, "Experimental Study of Spectral Parameters of Silicon-Vacancy Centers in MWCVD Nanodiamond Films Important for Sensing Applications," in Advanced Nanotechnologies for Detection and Defence against CBRN Agents, pp. 215-220, (2018).

16) M. Veres, L. Himics, I. Rigó, A. Nagy, S. Toth, S. Kugler, P. Baranyai, A. Czitrovszky, and T. Vaczi, "In vivo study of cell division with stimulated Raman scattering," in Proceedings - International Conference Laser Optics, pp. 548, (2018).

17) A. Nagy, M. Veres, I. Rigó, I. Vass, I. Kreisz, and A. Czitrovszky, "Characterisation of biological smoke generated by short pulse lasers," in Proceedings - International Conference Laser Optics, p. 604, (2018).

18) L. Himics, M. Veres, C. Popov, N. Felgen, T. Vaczi, I. Rigó, S. Tóth, and M. Koós, "Enhancement of the light emission of color center containing nanodiamond structures," in Proceedings - International Conference Laser Optics, pp. 392-392, (2018).

19) M. Veres, L. Himics, I. Rigó, T. S. Borossáné, R. Holomb, M. M.Hadi, and T. Váczi, "Indukált Raman-szórás femto-szekundumos lézerrel," in Kvantumelektronika, (2018).

20) A. Czitrovszky, A. Nagy, M. Veres, S. Kugler, I. Kreisz, I. Vass, and I. Rigó, "Measurements of surgical smoke using optical methods"," in 26th International Conference on Advanced Laser Technologies. Book of Abstracts, pp. 138-138, (2018).

21) Nagy, A. Czitrovszky, M. Veres, S. Kugler, I. Kreisz, I. Vass, and I. Rigó, "Characterization of the aerosol plume released during laser tissue interactions," in 26th International Conference on Advanced Laser Technologies. Book of Abstracts, pp. 139139, (2018).

22) L. Himics, M. Veres, M. Koós, S. Tóth, I. Rigó, P. Baranyai, T. Váczi, A. Czitrovszky, A. Nagy, R. Holomb, D. Oszetzky, N. Felgen, and C. Popov, "Multi-Wavelengths Fluorescence and Raman Spectroscopic Study of The SiV Center Containing Diamond Nanostructures," in 26th International Conference on Advanced Laser Technologies. Book of Abstracts, p. 150, (2018).

23) R. Holomb, M. Veres, O. Kondrat, I. Rigó, L. Himics, A. Czitrovszky, A. Csik, V. Takats, and V. Mitsa, "Synthesis, reversible laser modification and structural 
characterization of As-S based functional media for ultrafast photonics," in 26th International Conference on Advanced Laser Technologies. Book of Abstracts, p. 151, (2018).

24) M. Veres, L. Himics, I. Rigó, S. Tóth, P. Baranyai, A. Czitrovszky, and T. Váczi, “In Vivo Study of Intracellular Processes in Animal Embryo with Stimulated Raman Imaging," in 26th International Conference on Advanced Laser Technologies. Book of Abstracts, p. 137, (2018).

25) L. Himics, M. Veres, S. Tóth, I. Rigó, and M. Koós, "Origin of the asymmetric zerophonon line shape of the silicon-vacancy center in nanocrystalline diamond films," Journal of Luminescence, vol. 215, (2019).

26) S. Kugler, A. Nagy, A. Kerekes, M. Veres, I. Rigó, and A. Czitrovszky, "Determination of emitted particle characteristics and upper airway deposition of Symbicort ${ }^{\circledR}$ Turbuhaler dry powder inhaler," Journal Of Drug Delivery Science And Technology, vol. 54, (2019).

27) O. Hakkel, I. Rigó, M. Veres, and P. Fürjes, "Microfluidically Integrated SERS Active Cell Trap Array for Sensitive Analysis of Red Blood Cells," in 20th International Conference on Solid-State Sensors, Actuators and Microsystems and Eurosensors XXXIII (Transducers 2019 And Eurosensors XXXIII), pp. 964-967, (2019). 


\section{IRODALOMJEGYZÉK}

[1] J. R. Ferraro, K. Nakamoto and C. W. Brown, Chapter 1--Basic Theory BTIntroductory Raman Spectroscopy, San Diego: Academic Press, (2003).

[2] Г. С. Ландсберг and Л. И. Мандельштам, "Новое явление при рассеянии света (предварительное сообщение)," Журнал Русского физ.-хим. об-ва, vol. 60, pp. 335$338,(1928)$.

[3] C. V. Raman, "A change of wave-length in light scattering," Nature, vol. 121, p. 619, (1928).

[4] C. V. Raman and K. S. Krishnan, "A new type of secondary radiation," Nature, vol. 121, p. 501, (1928).

[5] R. Singh and F. Riess, "The 1930 Nobel Prize for Physics: a close decision?," Notes and Records of the Royal Society of London, vol. 55, pp. 267-283, (2001).

[6] R. A. Nyquist and R. O. Kagel, Handbook of infrared and raman spectra of inorganic compounds and organic salts: infrared spectra of inorganic compounds, vol. 4, Academic press, (2012).

[7] S. A. Holmstrom, T. H. Stievater, D. A. Kozak, M. W. Pruessner, N. Tyndall, W. S. Rabinovich, R. A. McGill and J. B. Khurgin, "Trace gas Raman spectroscopy using functionalized waveguides," Optica, vol. 3, pp. 891-896, (2016).

[8] E. Smith and G. Dent, Modern Raman spectroscopy: a practical approach, Wiley, (2013).

[9] K. Kamarás and A. Pekker, "Identification and separation of metallic and semiconducting carbon nanotubes," Oxford Handbook of Nanoscience and Technology: Volume 2: Materials: Structures, Properties and Characterization Techniques, vol. 2, p. 141, (2010).

[10] M. Votteler, D. A. Carvajal Berrio, M. Pudlas, H. Walles, U. A. Stock and K. SchenkeLayland, "Raman spectroscopy for the non-contact and non-destructive monitoring of collagen damage within tissues," Journal of biophotonics, vol. 5, pp. 47-56, (2012).

[11] E. J. Di Liscia, F. Alvarez, E. Burgos, E. B. Halac, H. Huck and M. Reinoso, "Stress analysis on single-crystal diamonds by Raman spectroscopy 3D mapping," Materials Sciences and Applications, (2013). 
[12] A. S. Paipetis, "Stress induced changes in the raman spectrum of carbon nanostructures and their composites," in Carbon nanotube enhanced aerospace composite materials, Springer, pp. 185-217, (2013).

[13] M. Lapp, C. M. Penney and L. M. Goldman, "Vibrational Raman scattering temperature measurements," Optics communications, vol. 9, pp. 195-200, (1973).

[14] R. Menzel, Photonics: linear and nonlinear interactions of laser light and matter, Springer Science \& Business Media, (2013).

[15] I. R. Lewis and H. Edwards, Handbook of Raman spectroscopy: from the research laboratory to the process line, CRC Press, (2001).

[16] J. Cazes, Analytical instrumentation handbook, CRC Press, (2004).

[17] „Raman Scattering and Fluorescence,” [Online]. Available: http://www.horiba.com/fileadmin/uploads/Scientific/Documents/Raman/Fluorescence 01.pdf. [Hozzáférés dátuma: 0408 2019].

[18] J.-G. Skinner and W. G. Nilsen, "Absolute Raman scattering cross-section measurement of the $992 \mathrm{~cm}-1$ line of benzene," Journal of the Optical Society of America, vol. 58, pp. 113-119, (1968).

[19] W. R. Fenner, H. A. Hyatt, J. M. Kellam and S. P. S. Porto, "Raman cross section of some simple gases," Journal of the Optical Society of America, vol. 63, pp. 73-77, (1973).

[20] M. Prochazka, surface-enhanced raman spectroscopy: Bioanalytical, Biomolecular and Medical Applications, Springer, (2017).

[21] R. Liu, J.-f. Liu, X.-x. Zhou and G.-b. Jiang, "Applications of Raman-based techniques to on-site and in-vivo analysis," TrAC Trends in Analytical Chemistry, vol. 30, pp. 1462-1476, (2011).

[22] A. G. Ryder, "Surface enhanced Raman scattering for narcotic detection and applications to chemical biology," Current opinion in chemical biology, vol. 9, pp. 489493, (2005).

[23] C. Yuen, W. Zheng and Z. Huang, "Surface-enhanced raman scattering: principles, nanostructures, fabrications, and biomedical applications," Journal of Innovative Optical Health Sciences, vol. 1, pp. 267-284, (2008). 
[24] M. E. Abdelsalam, P. N. Bartlett, J. J. Baumberg, S. Cintra, T. A. Kelf and A. E. Russell, "Electrochemical SERS at a structured gold surface," Electrochemistry Communications, vol. 7, pp. 740-744, (2005).

[25] S. Wei, M. Zheng, Q. Xiang, H. Hu and H. Duan, "Optimization of the particle density to maximize the SERS enhancement factor of periodic plasmonic nanostructure array," Optics express, vol. 24, pp. 20613-20620, (2016).

[26] A. Pallaoro, G. B. Braun and M. Moskovits, "Biotags based on surface-enhanced Raman can be as bright as fluorescence tags," Nano letters, vol. 15, pp. 6745-6750, (2015).

[27] A. Y. Panarin, V. S. Chirvony, K. I. Kholostov, P.-Y. Turpin and S. N. Terekhov, "Formation of SERS-active silver structures on the surface of mesoporous silicon," Journal of Applied Spectroscopy, vol. 76, pp. 280-287, (2009).

[28] D. Graham, M. Moskovits and Z.-Q. Tian, "SERS--facts, figures and the future," Chemical Society Reviews, vol. 46, pp. 3864-3865, (2017).

[29] P. Larkin, Infrared and Raman spectroscopy: principles and spectral interpretation, Elsevier, (2017).

[30] R. W. Boyd, Nonlinear optics, Elsevier, (2008).

[31] D. L. Andrews and A. A. Demidov, An introduction to laser spectroscopy, Springer Science \& Business Media, (2012).

[32] E. Le Ru and P. Etchegoin, Principles of Surface-Enhanced Raman Spectroscopy: and related plasmonic effects, Elsevier, (2008).

[33] E. C. Le Ru, M. Meyer, E. Blackie and P. G. Etchegoin, "Advanced aspects of electromagnetic SERS enhancement factors at a hot spot," Journal of Raman Spectroscopy: An International Journal for Original Work in all Aspects of Raman Spectroscopy, Including Higher Order Processes, and also Brillouin and Rayleigh Scattering, vol. 39, pp. 1127-1134, (2008).

[34] R. Pilot, R. Signorini, C. Durante, L. Orian, M. Bhamidipati and L. Fabris, "A review on surface-enhanced Raman scattering," Biosensors, vol. 9, p. 57, (2019).

[35] K. Yee, "Numerical solution of initial boundary value problems involving Maxwell's equations in isotropic media," IEEE Transactions on antennas and propagation, vol. 14, pp. 302-307, (1966). 
[36] Z. Zeng, Y. Liu and J. Wei, "Recent advances in surface-enhanced raman spectroscopy (SERS): Finite-difference time-domain (FDTD) method for SERS and sensing applications," TrAC Trends in Analytical Chemistry, vol. 75, pp. 162-173, (2016).

[37] „Spectroscopy/Molecular energy levels,” [Online]. Available: https://en.wikiversity.org/wiki/Spectroscopy/Molecular_energy_levels. [Hozzáférés dátuma: 0408 2019].

[38] Y. B. Band and Y. Avishai, Quantum mechanics with applications to nanotechnology and information science, Academic Press, (2013).

[39] E. B. Wilson, J. C. Decius and P. C. Cross, Molecular vibrations: the theory of infrared and Raman vibrational spectra, Courier Corporation, (1980).

[40] T. Váczi, Raman-spektroszkópia, Miskolci Egyetem, (2011).

[41] D. C. Harris and M. D. Bertolucci, Symmetry and spectroscopy: an introduction to vibrational and electronic spectroscopy, Courier Corporation, (1989).

[42] C. Kittel, Bevezetés a szilárdtest-fizikába, Műszaki kiadó., (1981).

[43] „Dispersion relations and phonons," [Online]. Available: http://users.aber.ac.uk/ruw/teach/334/disprel.php. [Hozzáférés dátuma: 2306 2019].

[44] H. Azhari, "Propagation of acoustic waves in solid materials," pp. 75-92, (2010).

[45] „latticevibrations:phononscattering,” [Online]. Available: https://www.cambridge.org/mx/files/8813/6689/8934/2064_ch06.pdf. [Hozzáférés dátuma: 0408 2019].

[46] S. A. Maier, M. L. Brongersma, P. G. Kik, S. Meltzer, A. A. G. Requicha, B. E. Koel and H. A. Atwater, "Plasmonics - A route to nanoscale optical devices," Advanced Materials, vol. 15, pp. 562-562, (2003).

[47] J.-H. Hooijschuur, M. F. C. Verkaaik, G. R. Davies and F. Ariese, "Will Raman meet bacteria on Mars? An overview of the optimal Raman spectroscopic techniques for carotenoid biomarkers detection on mineral backgrounds," Netherlands Journal of Geosciences, vol. 95, pp. 141-151, (2016).

[48] J. Sólyom, Fundamentals of the Physics of Solids: Volume 1: Structure and Dynamics, vol. 1, Springer Science \& Business Media, (2007).

[49] W. Heitler, "The Quantum Theory of Radiation, 2-nd ed," Oxford, vol. 13, p. 170, (1944). 
[50] „RAMAN SHIFT CALCULATOR,”[Online]. Available: http://photonetc.com/ramanshift-calculator. [Hozzáférés dátuma: 0408 2019].

[51] D. W. Hahn, "Raman scattering theory," Department of Mechanical and Aerospace Engineering, University of Florida, (2007).

[52] G. Turrell and J. Corset, Raman microscopy: developments and applications, Academic Press, (1996).

[53] N. Colthup, Introduction to infrared and Raman spectroscopy, Elsevier, (2012).

[54] D. A. Long, "The Raman effect: a unified treatment of the theory of Raman scattering by molecules. 2002," West Sussex, England: John Wiley \& Sons Ltd, (2002).

[55] M. Kotlarchyk, "Scattering theory," Encyclopedia of Spectroscopy and Spectrometry (Second Edition), pp. 2495-2503, (1999).

[56] H. Kuzmany, "Phonon Structures and Raman Effect of Carbon Nanotubes and Graphene," in Carbon Nanotubes and Graphene, Elsevier, (2014), pp. 99-149.

[57] P. Misra, Physics of condensed matter, Academic Press, (2011).

[58] C. Manuel, Ed., Light scattering in solids I., Springer, Berlin, (1983).

[59] M. Fleischmann, P. J. Hendra and A. J. McQuillan, "Raman spectra of pyridine adsorbed at a silver electrode," Chemical physics letters, vol. 26, pp. 163-166, (1974).

[60] D. L. Jeanmaire and R. P. Van Duyne, "Surface Raman spectroelectrochemistry: Part I. Heterocyclic, aromatic, and aliphatic amines adsorbed on the anodized silver electrode," Journal of electroanalytical chemistry and interfacial electrochemistry, vol. 84 , pp. 1-20, (1977).

[61] M. G. Albrecht and J. A. Creighton, "Anomalously intense Raman spectra of pyridine at a silver electrode," Journal of the american chemical society, vol. 99, pp. 5215-5217, (1977).

[62] M. Moskovits, "Surface roughness and the enhanced intensity of Raman scattering by molecules adsorbed on metals," The Journal of Chemical Physics, vol. 69, pp. 41594161, (1978).

[63] M. Moskovits, "Surface-enhanced spectroscopy," Reviews of modern physics, vol. 57, p. 783,1985 .

[64] S.-Y. Ding, E.-M. You, Z.-Q. Tian and M. Moskovits, "Electromagnetic theories of surface-enhanced Raman spectroscopy," Chemical Society Reviews, vol. 46, pp. 4042 4076, (2017). 
[65] S. M. Morton and L. Jensen, "Understanding the molecule- surface chemical coupling in SERS," J. Am. Chem. Soc, vol. 131, pp. 4090-4098, (2009).

[66] J.-F. Li, Y.-F. Huang, S. Duan, R. Pang, D.-Y. Wu, B. Ren, X. Xu and Z.-Q. Tian, "SERS and DFT study of water on metal cathodes of silver, gold and platinum nanoparticles," Physical Chemistry Chemical Physics, vol. 12, pp. 2493-2502, (2010).

[67] S. Nie and S. R. Emory, "Probing single molecules and single nanoparticles by surfaceenhanced Raman scattering," Science, vol. 275, pp. 1102-1106, (1997).

[68] J. R. Lombardi and R. L. Birke, "A unified view of surface-enhanced Raman scattering," Accounts of chemical research, vol. 42, pp. 734-742, (2009).

[69] A. Otto, "Charge transfer in first layer enhanced Raman scattering and surface resistance," Quarterly Physics Review, vol. 3, pp. 1-14, (2017).

[70] A. Otto, "The 'chemical'(electronic) contribution to surface-enhanced Raman scattering," Journal of Raman Spectroscopy: An International Journal for Original Work in all Aspects of Raman Spectroscopy, Including Higher Order Processes, and also Brillouin and Rayleigh Scattering, vol. 36, pp. 497-509, (2005).

[71] L. Jensen, C. M. Aikens and G. C. Schatz, "Electronic structure methods for studying surface-enhanced Raman scattering," Chemical Society Reviews, vol. 37, pp. 10611073, (2008).

[72] R. L. Birke, V. Znamenskiy and J. R. Lombardi, "A charge-transfer surface enhanced Raman scattering model from time-dependent density functional theory calculations on a $\mathrm{Ag} \mathrm{10-}$ pyridine complex," The Journal of chemical physics, vol. 132, p. 214707, (2010).

[73] A. A. Kowalska, A. Kaminska, W. Adamkiewicz, E. Witkowska and M. Tkacz, "Novel highly sensitive $\mathrm{Cu}$-based SERS platforms for biosensing applications," Journal of Raman Spectroscopy, vol. 46, pp. 428-433, (2015).

[74] A. Shiohara, Y. Wang and L. M. Liz-Marzán, "Recent approaches toward creation of hot spots for SERS detection," Journal of Photochemistry and Photobiology C: Photochemistry Reviews, vol. 21, pp. 2-25, (2014).

[75] V. Amendola, R. Pilot, M. Frasconi, O. M. Marago and M. A. Iati, "Surface plasmon resonance in gold nanoparticles: a review," Journal of Physics: Condensed Matter, vol. 29, p. 203002, (2017).

[76] E. C. Le Ru and P. G. Etchegoin, "Quantifying SERS enhancements," MRS bulletin, vol. 38, pp. 631-640, (2013). 
[77] V. P. Polubotko, "The Theory of SERS on Dielectrics and Semiconductors," arXiv preprint arXiv:1609.09403, (2016).

[78] M. A. Ordal, L. L. Long, R. J. Bell, S. E. Bell, R. R. Bell, R. W. Alexander and C. A. Ward, "Optical properties of the metals al, co, cu, au, fe, pb, ni, pd, pt, ag, ti, and w in the infrared and far infrared," Applied optics, vol. 22, pp. 1099-1119, (1983).

[79] J. Sólyom, Fundamentals of the Physics of Solids: Volume II: Electronic Properties, vol. 2, Springer Science \& Business Media, (2008).

[80] J. M. Seminario, Design and applications of nanomaterials for sensors, Springer, 2014.

[81] E. D. Palik, Handbook of optical constants of solids, vol. 3, Academic press, (1998).

[82] K. A. Willets and R. P. Van Duyne, "Localized surface plasmon resonance spectroscopy and sensing," Annu. Rev. Phys. Chem., vol. 58, pp. 267-297, (2007).

[83] A. P. Vinogradov, A. V. Dorofeenko, A. A. Pukhov and A. A. Lisyansky, "Exciting surface plasmon polaritons in the Kretschmann configuration by a light beam," Physical Review B, vol. 97, pp. 235-407, (2018).

[84] J. D. Jackson, Classical electrodynamics, John Wiley \& Sons, (1999).

[85] P. K. Jain and M. A. El-Sayed, "Plasmonic coupling in noble metal nanostructures," Chemical Physics Letters, vol. 487, pp. 153-164, (2010).

[86] T. Chen, M. Pourmand, A. Feizpour, B. Cushman and B. M. Reinhard, "Tailoring plasmon coupling in self-assembled one-dimensional Au nanoparticle chains through simultaneous control of size and gap separation," The journal of physical chemistry letters, vol. 4, pp. 2147-2152, (2013).

[87] S. L. Kleinman, R. R. Frontiera, A.-I. Henry, J. A. Dieringer and R. P. Van Duyne, "Creating, characterizing, and controlling chemistry with SERS hot spots," Physical Chemistry Chemical Physics, vol. 15, pp. 21-36, (2013).

[88] S. M. Stranahan and K. A. Willets, "Super-resolution optical imaging of singlemolecule SERS hot spots," Nano letters, vol. 10, pp. 3777-3784, (2010).

[89] G. Braun, I. Pavel, A. R. Morrill, D. S. Seferos, G. C. Bazan, N. O. Reich and M. Moskovits, "Chemically patterned microspheres for controlled nanoparticle assembly in the construction of SERS hot spots," Journal of the american chemical society, vol. 129, pp. 7760-7761, (2007). 
[90] P. Andrew and W. L. Barnes, "Förster energy transfer in an optical microcavity," Science, vol. 290, pp. 785-788, (2000).

[91] L. Novotny and B. Hecht, Principles of Nano-Optics, Cambridge University Press, (2006).

[92] R. Pilot, "SERS detection of food contaminants by means of portable Raman instruments," Journal of Raman Spectroscopy, vol. 49, pp. 954-981, (2018).

[93] P. L. Stiles, J. A. Dieringer, N. C. Shah and R. P. Van Duyne, "Surface-enhanced Raman spectroscopy," Annual Review of Analytical Chemistry., vol. 1, pp. 601-626, (2008).

[94] „Surface Enhanced Raman Scattering,” [Online]. Available: https://apps.lumerical.com/sp_sers.html. [Hozzáférés dátuma: 1009 2019].

[95] S. D. Gedney, "Introduction to the finite-difference time-domain (FDTD) method for electromagnetics," Synthesis Lectures on Computational Electromagnetics, vol. 6, pp. $1-250,(2011)$.

[96] I. Laakso, „Introduction to the FDTD method,” [Online]. Available: https://mycourses.aalto.fi/pluginfile.php/153434/mod_resource/content/1/Introduction \%20to\%20FDTD.pdf. [Hozzáférés dátuma: 1009 2019].

[97] A. Folch, Introduction to bioMEMS, CRC Press, (2016).

[98] P. Fürjes, A. Kovacs, C. Dücso, M. Ádám, B. Müller and U. Mescheder, "Porous silicon-based humidity sensor with interdigital electrodes and internal heaters," Sensors and Actuators B: Chemical, vol. 95, pp. 140-144, (2003).

[99] A. Pongrácz, Z. Fekete, G. Márton, Z. Bérces, I. Ulbert and P. Fürjes, "Deep-brain silicon multielectrodes for simultaneous in vivo neural recording and drug delivery," Sensors and Actuators B: Chemical, vol. 189, pp. 97-105, (2013).

[100] E. Holczer and P. Fürjes, "Effects of embedded surfactants on the surface properties of PDMS; applicability for autonomous microfluidic systems," Microfluidics and Nanofluidics, vol. 21, p. 81, (2017).

[101] E. Holczer, O. Hakkel and P. Fürjes, "Fabrication of Hybrid Microfluidic System on Transparent Substrates for Electrochemical Applications," in Multidisciplinary Digital Publishing Institute Proceedings, (2017).

[102] E. Horváth, Fókuszált ionsugaras nanomegmunkálás, MTA Műszaki Fizikai És Anyagtudományi Kutatóintézet, (2009). 
[103] J. X. J. Zhang and K. Hoshino, Molecular Sensors and Nanodevices: Principles, Designs and Applications in Biomedical Engineering, Academic Press, (2018).

[104] „Fabricating MEMS and Nanotechnology,” [Online]. Available: https://www.memsnet.org/about/fabrication.html. [Hozzáférés dátuma: 0408 2019].

[105] K. E. Bean, "Anisotropic etching of silicon," IEEE Transactions on electron devices, vol. 25, pp. 1185-1193, (1978).

[106] A. J. Nijdam, "Anisotropic wet-chemical etching of silicon pits, peaks, principles, pyramids and particles," University of Twente, (2001).

[107] M. A. Hopcroft, W. D. Nix and T. W. Kenny, "What is the Young's Modulus of Silicon?," Journal of microelectromechanical systems, vol. 19, pp. 229-238, (2010).

[108] K. Sato, M. Shikida, T. Yamashiro, K. Asaumi, Y. Iriye and M. Yamamoto, "Anisotropic etching rates of single-crystal silicon for TMAH water solution as a function of crystallographic orientation," Sensors and Actuators A: Physical, vol. 73, pp. 131-137, (1999).

[109] S. Dutta, M. Imran, P. Kumar, R. Pal, P. Datta and R. Chatterjee, "Comparison of etch characteristics of KOH, TMAH and EDP for bulk micromachining of silicon (110)," Microsystem technologies, vol. 17, p. 1621, (2011).

[110] N. P. Mahalik, Micromanufacturing and nanotechnology, Springer, (2006).

[111] H. H. Gatzen, V. Saile and J. Leuthold, Micro and nano fabrication, Springer, (2016).

[112] „Wet-chemical etching of silicon and SiO2," [Online]. Available: https://www.microchemicals.eu/technical_information/silicon_etching.pdf. [Hozzáférés dátuma: 2208 2019].

[113] J. Frühauf, E. Gärtner and S. Krönert, Shape and functional elements of the bulk silicon microtechnique, Springer, (2005).

[114] G. D'Arrigo, A. Severino, G. Milazzo, C. Bongiorno, N. Piluso, G. Abbondanza, M. Mauceri, G. Condorelli and F. La Via, "3C-SiC heteroepitaxial growth on inverted silicon pyramids (ISP)," in Materials Science Forum, (2010).

[115] J. Albero, L. Nieradko, C. Gorecki, H. Ottevaere, V. Gomez, H. Thienpont, J. Pietarinen, B. Päivänranta and N. Passilly, "Fabrication of spherical microlenses by a combination of isotropic wet etching of silicon and molding techniques," Optics express, vol. 17, pp. 6283-6292, (2009). 
[116] Y. Wang, L. Yang, Y. Liu, Z. Mei, W. Chen, J. Li, H. Liang, A. Kuznetsov and D. Xiaolong, "Maskless inverted pyramid texturization of silicon," Scientific reports, vol. 5, (2015).

[117] "3D Optical Profiler Manuals," [Online]. Available: https://www.zygo.com/?sup=/resource/manuals.cgi?type=profilers. [Hozzáférés dátuma: 2208 2019].

[118] H. Ozdemir, "Comparison of linear, cubic spline and akima interpolation methods,", [Online]. Available:

http://www.jive.nl/jivewiki/lib/exe/fetch.php?media=expres:fabric:interpolation.pdf [Hozzáférés dátuma: 2208 2019].

[119] E. Roth and P. Fredericks, "Simple technique for measuring Fourier transform surfaceenhanced Raman spectra of organic compounds," in 9th International Conference on Fourier Transform Spectroscopy, (1994).

[120] Y. Fleger, Y. Mastai, M. Rosenbluh and D. H. Dressler, "Surface enhanced Raman spectroscopy of aromatic compounds on silver nanoclusters," Surface Science, vol. 603, pp. 788-793, (2009).

[121] E. Droghetti, F. P. Nicoletti, L. Guandalini, G. Bartolucci and G. Smulevich, "SERS detection of benzophenones on viologen functionalized Ag nanoparticles," Journal of Raman Spectroscopy, vol. 44, pp. 1428-1434, (2013).

[122] L. Babkov, J. Baran, N. A. Davydova, V. I. Mel'nik and K. E. Uspenskiy, "Raman spectra of metastable phase of benzophenone," Journal of molecular structure, vol. 792, pp. 73-77, (2006).

[123] G. Varsányi, Vibrational spectra of benzene derivatives, Elsevier, (2012).

[124] J. Blažević and L. Colombo, "The vibrational spectrum of the benzophenone molecule," Journal of Raman Spectroscopy, vol. 11, pp. 143-149, (1981).

[125] R. C. Weast, M. J. Astle, W. H. Beyer and others, CRC handbook of chemistry and physics, vol. 69, CRC press Boca Raton, FL, (1988).

[126] R. Eli and B. Gersh, Kinetic Theory of Nucleation, CRC Press Illustrations, (2016).

[127] W.-D. Li, F. Ding, J. Hu and S. Y. Chou, "Three-dimensional cavity nanoantenna coupled plasmonic nanodots for ultrahigh and uniform surface-enhanced Raman scattering over large area," Optics express, vol. 19, pp. 3925-3936, (2011). 
[128] K. Kim, H. B. Lee and K. S. Shin, "Surface-enhanced Raman scattering characteristics of nanogaps formed by a flat Ag substrate and spherical Pt nanoparticles," Spectrochimica Acta Part A: Molecular and Biomolecular Spectroscopy, vol. 100, pp. 10-14, (2013).

[129] I. Yoon, T. Kang, W. Choi, J. Kim, Y. Yoo, S.-W. Joo, Q.-H. Park, H. Ihee and B. Kim, "Single nanowire on a film as an efficient SERS-active platform," Journal of the American Chemical Society, vol. 131, pp. 758-762, (2008).

[130] R. Yury, M. David and D. John F., "Photonic nanojets in coupled microcavities," The European Conference on Lasers and Electro-Optics, (2009).

[131] T. Jakub, Š. Václav and E. Petra, "The Preparation of Composite Material of Graphene Oxide-Polystyrene," 3rd International Conference on Environment, Chemistry and Biology, (2014).

[132] J. R. Anema, A. G. Brolo, A. Felten and C. Bittencourt, "Surface-enhanced Raman scattering from polystyrene on gold clusters," Journal of Raman Spectroscopy, vol. 41, pp. 745-751, (2010).

[133] B. R. Wood and D. McNaughton, "Raman excitation wavelength investigation of single red blood cells in vivo," Journal of Raman Spectroscopy, vol. 33, pp. 517-523, (2002).

[134] S. Hu, K. M. Smith and T. G. Spiro, "Assignment of protoheme resonance Raman spectrum by heme labeling in myoglobin," Journal of the American Chemical Society, vol. 118, pp. 12638-12646, (1996).

[135] M. Abe, T. Kitagawa and Y. Kyogoku, "Resonance Raman spectra of octaethylporphyrinato$\mathrm{Ni}$ (II) and meso-deuterated and $15 \mathrm{~N}$ substituted derivatives. II. A normal coordinate analysis," The Journal of Chemical Physics, vol. 69, pp. 4526-4534, (1978).

[136] B. R. Wood, P. Caspers, G. J. Puppels, S. Pandiancherri and D. McNaughton, "Resonance Raman spectroscopy of red blood cells using near-infrared laser excitation," Analytical and bioanalytical chemistry, vol. 387, pp. 1691-1703, (2007).

[137] J. W. Chan, D. S. Taylor, T. Zwerdling, S. M. Lane, K. Ihara and T. Huser, "MicroRaman spectroscopy detects individual neoplastic and normal hematopoietic cells," Biophysical journal, vol. 90, pp. 648-656, (2006).

[138] N. Stone, C. Kendall, J. Smith, P. Crow and H. Barr, "Raman spectroscopy for identification of epithelial cancers," Faraday discussions, vol. 126, pp. 141-157, (2004). 
[139] A. M. K. Enejder, T.-W. Koo, J. Oh, M. Hunter, S. Sasic, M. S. Feld and G. L. Horowitz, "Blood analysis by Raman spectroscopy," Optics letters, vol. 27, pp. 20042006, (2002).

[140] A. A. Lykina, D. N. Artemyev, I. A. Bratchenko, Y. A. Khristoforova, O. O. Myakinin, T. P. Kuzmina, I. L. Davydkin and V. P. Zakharov, "Raman spectra analysis of human blood protein fractions using the projection on latent structures method," in CEUR Workshop Proceedings, (2017).

[141] P. G. Etchegoin and E. C. Le Ru, "Basic electromagnetic theory of SERS," Surface Enhanced Raman Spectroscopy, pp. 1-37, (2011).

[142] Y. Kitahama, Y. Nishiyama and Y. Ozaki, "Blinking Surface-Enhanced Raman Scattering and Fluorescence From a Single Silver Nanoaggregate Simultaneously Analyzed by Bi-Color Intensity Ratios and a Truncated Power Law," The Journal of Physical Chemistry C, vol. 122, pp. 22106-22113, (2018).

[143] R. M. Dickson, A. B. Cubitt, R. Y. Tsien and W. E. Moerner, "On/off blinking and switching behaviour of single molecules of green fluorescent protein," Nature, vol. 388, p. $355,(1997)$.

[144] J. Yu, D. Hu and P. F. Barbara, "Unmasking electronic energy transfer of conjugated polymers by suppression of O2 quenching," Science, vol. 289, pp. 1327-1330, (2000).

[145] A. Sujith, T. Itoh, H. Abe, A. A. Anas, K. Yoshida, V. Biju and M. Ishikawa, "Surface enhanced Raman scattering analyses of individual silver nanoaggregates on living single yeast cell wall," Applied Physics Letters, vol. 92, p. 103901, (2008).

[146] S. R. Emory, R. A. Jensen, T. Wenda, M. Han and S. Nie, "Re-examining the origins of spectral blinking in single-molecule and single-nanoparticle SERS," Faraday discussions, vol. 132, pp. 249-259, (2006).

[147] Z. Wang and L. J. Rothberg, "Origins of blinking in single-molecule Raman spectroscopy," The Journal of Physical Chemistry B, vol. 109, pp. 3387-3391, (2005).

[148] A. Weiss and G. Haran, "Time-dependent single-molecule Raman scattering as a probe of surface dynamics," The Journal of Physical Chemistry B, vol. 105, pp. 12348-12354, (2001).

[149] M. Moskovits, L.-L. Tay, J. Yang and T. Haslett, "SERS and the single molecule," in Optical properties of nanostructured random media, Springer, pp. 215-227, (2002). 


\section{KÖSZÖNETNYILVÁNÍTÁS / ACKNOWLEDGEMENT}

Köszönettel tartozom témavezetőmnek, Veres Miklósnak a folyamatos támogatásáért, hasznos tanácsaiért és útmutatásaiért, a kutatási infrastruktúra megteremtéséért, valamint, hogy nem csak témavezetőként támogatott, hanem erkölcsi szempontból is mindig mellettem állt.

Köszönettel és hálával tartozom Fürjes Péternek és Hakkel Orsolyának a minták előállításában, SEM képeinél nyújtott segítségükért, innovatív ötleteikért, valamint, hogy mindig bizalommal fordulhattam hozzájuk. Nélkülük ez a munka nem jöhetett volna létre.

Köszönöm Kamarás Katalinnak és Bonyár Attilának a rengeteg időt és energiát, amit a dolgozat áttanulmányozására fordítottak, valamint a jó meglátásokat és a megfogalmazott kritikákat.

Köszönet illeti a kutatócsoportunk további tagjait, Váczi Tamást, Himics Lászlót, Holomb Románt, Baranyi Pétert kutatásaimhoz nyújtott segítségükért. Köszönet Pápa Zsuzsannának a szimulációs feladatok során nyújtott konzultációkért.

Köszönetet szeretnék mondani a dolgozat megírásakor SZFI igazgató, Czitrovszky Aladárnak, a kutatómunkámhoz szükséges megfelelő légkör biztosításáért.

Szeretnék köszönetet mondani édesanyámnak, valamint édesapámnak - aki nem élhette meg a dolgozat elkészültét - testvéreimnek és feleségem szüleinek és mindazoknak, akik valamilyen módon hozzájárultak a dolgozatom elkészítéséhez.

Végezetül, de nem utolsó sorban pedig köszönöm a feleségemnek, Petra Renátának a mérhetetlen türelmet, támogatást és szeretetet, az otthon biztonságát - nehéz kifejezni, mi mindent köszönhetek neki -, a Maslow-piramis értelmében az alapot adta, amire az eredmények épülhettek. Kislányomnak, Hannának, pedig, hogy erőt adott és hagyta megírnom a dolgozatot.

A doktori munka a Nemzeti Kutatási Fejlesztési és Innovációs Alapból biztosított támogatással, a VEKOP-2.3.2-16, valamint a 2018-1.2.1-NKP pályázati program finanszírozásában valósult meg a VEKOP-2.3.2-16-2016-00011 és 2018-1.2.1-NKP-201800012 számú projektek keretein belül.

The Thesis have been supported by the National Research Development and Innovation Fund, in the financing of the VEKOP-2.3.2-16 and the 2018-1.2.1-NKP research program, in frames of VEKOP-2.3.2-16-2016 -00011 and 2018-1.2.1-NKP-2018-00012 projects. 